\title{
Revisiting External Imbalances: Insights from Sectoral Accounts
}

\author{
Cían Allen* \\ Trinity College Dublin
}

This draft: October 2018

Latest draft: Here

\begin{abstract}
This paper revisits the period of substantial widening of external imbalances in advanced economies in the run-up to the global financial crisis and their adjustment since then. We take a granular look at these imbalances through the lens of their domestic counterpart: the net financial balance of the household sector, the government, non-financial corporations, and financial corporations. Our findings challenge the often-claimed view that the household sector lies behind most of the dynamics of the current account. In fact, we show that it is the non-financial corporation and the government sectors that account for the bulk of: (i) the co-movement with the standard set of fundamental covariates of the current account; (ii) the external adjustment and expenditure reduction in the aftermath of the global financial crisis; and (iii) the diverging dynamics during large and persistent current account imbalances. These results emphasize that analyzing domestic sectoral balances can lead to a better empirical and theoretical understanding of global imbalances.
\end{abstract}

JEL-Code: F31, F32, E21

Keywords: current account; external adjustment; sectoral balance; flow of funds.

*Cían Allen (allenc4@tcd.ie), PhD candidate at Trinity College Dublin under the supervision of Philip R. Lane, whom I wish to thank for ideas, guidance, and support. I also thank for helpful comments Agustin Benetrix, Vahagn Galstyan, Peter McQuade, Rogelio Mercado, Davide Romelli, and participants at the IMF EUR seminar, the EEA congress (Cologne), the CEBRA annual meeting (Frankfurt), the ECB's 2018 forum (Sintra), and the TCD working group. This research is supported by the Government of Ireland Postgraduate Scholarship programme from the Irish Research Council. Part of this article was drafted while I was visiting UC Berkeley. I am grateful to Pierre-Olivier Gourinchas for making this possible. All remaining errors are my own. 


\section{Introduction}

Understanding the dynamics of external imbalances remains at the forefront of both the academic and policy agenda. In the past few decades, financial globalization has led to a well-documented widening of current account balances. Despite a large and costly contraction of global imbalances in the aftermath of the global financial crisis, significant current account deficits and surpluses persist, particularly in advanced economies. ${ }^{1}$ Much less discussed, however, is the domestic counterpart of these imbalances, the net financial balances of the household sector (HH), the government (GOV), non-financial corporations (NFC), and financial corporations (FC). Each net financial balance represents the saving-investment balance of that sector (or alternatively income-expenditure balance of that sector) and their sum is equal to the current account. ${ }^{2,3}$

Consider a country that is running a current account deficit (that is, with a level of domestic spending that exceeds domestic output, or alternatively a level of investment that exceeds saving). Accordingly, this country is a net borrower from the rest of the world, which entails well-known risks (Blanchard, 2007). Given the economy-wide resource constraint explained above, this external deficit will be reflected in a deficit in at least one of the domestic sectors. Typically, one would expect the NFC sector to run a net financial deficit, i.e. to borrow in order to fund investment, and the $\mathrm{HH}$ sector to run a net financial surplus, i.e. to be a net saver, with the FC sector intermediating the funds.

In fact, it is often assumed that the $\mathrm{HH}$ sector plays a central role in explaining the behavior of the current account. In the standard intertemporal model, the current account is the result of forward-looking saving decisions made by the representative household and investment decisions made by firms (Obstfeld and Rogoff, 1995). In principle, as the firms are fully owned by the representative agent (in other words, there is no "corporate veil"), the identity of the saving and investing sector has no importance. ${ }^{4}$ However, the recent wave of puzzling net financial surpluses in certain advanced economies (see for instance Chen et al. 2017), the pervasive role of global firms and global investors (Avdjiev et al., 2018), and the lack of any clear relationship in the data between the net saving of the $\mathrm{HH}$ sector and the current account, suggest the presence of distortions or a corporate veil. ${ }^{5}$

This paper revisits the core question of external imbalances and their adjustment in advanced economies through the lens of domestic sectoral balances over the 1995-2015 period. Our results challenge the often-claimed view that the household sector plays a central role in current account dynamics. We show the government and non-financial corporation sectors account for the bulk of

\footnotetext{
${ }^{1}$ See Menzie D. Chinn's Jackson Hole speech (Chinn, 2017).

${ }^{2}$ The net transactions between domestic sectors cancel out at the aggregate level, giving us the net resource flow with the rest of the world.

${ }^{3}$ Although less discussed in the academic literature, the financial press and policy circles have highlighted the insights of net financial balances (see Martin Wolf (Financial Times, November, 2015), Matthew C. Klein (Barron's, July, 2018), IMF (2017), and Guntram B. Wolff (Bruegel, May, 2018) for recent examples).

${ }^{4}$ The extent to which households pierce the corporate veil, in particular, if they change their consumption differently in response to capital gain or a dividend payout, has been the source of many debates (see for instance Poterba, 1987).

${ }^{5}$ In particular, financial globalization has delinked domestic households and ownership of the corporate sector, as the share of foreign ownership of the domestic corporate sector grew from 15 to 30 percent from 1995 to 2015 in our sample of countries (Allen, 2018).
} 
these patterns. These results hold for our three broad lines of analysis. First, we offer a new take on the standard medium-term covariates of external imbalances and show that the bulk of the explanatory power of these variables is accounted for in the GOV and NFC sectors. Second, we reexamine the post-crisis external adjustment process and find that it was mainly reflected in expenditure reduction in the corporate sector as opposed to the $\mathrm{HH}$ sector. These results are consistent with the narrative of external adjustment through expenditure reduction instead of expenditure switching, established by Lane and Milesi-Ferretti (2012). In other words, a large share of the closing of current account imbalances happened through increases in NFC saving or a reduction of investment, as opposed to a reduction of consumption by the HH sector. ${ }^{6}$ Finally, we study the accumulation of wealth or build-up of liabilities in the domestic sectors during episodes of large and persistent capital inflows (or current account deficits) and outflows (or current account surpluses). We find that the HH sector accumulates similar net financial surpluses in both types of episodes. Overall, these findings can provide guidance for future empirical and theoretical research in international macroeconomics.

Our contribution is linked to the ever-expanding literature on the patterns of international balance sheets and capital flows. Recent papers have highlighted aggregate patterns of cross-border capital flows are not always indicative of underlying cross-border sectoral relationships (see Alfaro et al. (2014), Galstyan et al. (2016), Avdjiev et al. (2017), and Cerutti and Hong (2018) for instance). Avdjiev et al. (2017) in particular show that in advanced economies most direct cross-border financial transactions are undertaken by banks. However, focusing solely on sector cross-border transactions does not give us a clear understanding of which sectors of the economy are the underlying counterpart of foreign borrowing due to the intermediation role of banks (Lane, 2015). For instance, firms or households can borrow directly from the rest of the world or indirectly through the banking sector. In both cases, shifts in the financial balances of these sectors will be associated with a corresponding shift in the current account. Studying domestic balances and the current account in tandem, allows to capture the vulnerabilities arising from both of these cases, unlike the previously cited papers.

Our paper is also related to the large literature that studied the relationship between current account balances and a set of economic fundamentals, with the idea in mind that balanced current accounts were not the correct benchmark for external sustainability (see, for example, Chinn and Prasad (2003), Chinn and Ito (2007), Lane and Milesi-Ferretti (2012), and Phillips et al. (2013)). ${ }^{7}$ Indeed, current account deficits can be consistent with underlying economic fundamentals, such as demographics or levels of development. Understanding how these covariation patterns are reflected in the medium-term fluctuations of sectoral balances can yield valuable insights. Additionally, prior to the crisis current account imbalances often exceeded levels consistent with these fundamentals, contributing to the severity of the post-crisis adjustment, as highlighted by Lane and Milesi-Ferretti $(2012,2015)$. Up until now, it was not known how these findings carried through to the sectoral level.

\footnotetext{
${ }^{6}$ McCauley et al. (2017) show that most of the cross-border contraction in flows was due to a decrease in crossborder banking. We show that in terms of domestic saving-investment balances, this is reflected mainly in the NFC sector.

${ }^{7}$ As the object of this paper is not to establish new drivers of the current account, but to study their relationship with the domestic sectoral counterpart of the current account, our regressions resemble the ones of the papers cited above.
} 
We document the contribution of each sector balance to the closing of these excessive imbalances. Moreover, this paper is also related to the literature on episodes of current account reversals (see Milesi-Ferretti and Razin (2000), Calvo et al. (2004), Mendoza (2010), and Forbes and Warnock (2014) amongst others), balance sheet recessions (Koo, 2013), and the sustainability of net external positions (see Gourinchas and Rey (2007), Turrini and Zeugner (2018), and Adler and Garcia-Macia (2018) for recent examples).

Moreover, given the importance of the corporate sector in our results, this research is related to the growing literature that documents higher corporate (retained) earnings and shift of the corporate sector from a net borrower to a net saver. Competing explanations for this trend include rising profits on the back of decreasing labor shares (Chen et al., 2017), under-investment (Gruber and Kamin, 2016), financial frictions issues in Emerging Asia (see amongst others Bacchetta and Benhima (2015) and Fan and Kalemli-Ozcan (2016)), corporate governance (Aoyagi and Ganelli (2017) Bayoumi et al. (2012) for example) and the growing of importance of intangible capital (Falato et al., 2013). In addition, Zetlin-Jones and Shourideh (2017) show that the decision for a firm to fund itself externally or internally has implications for the propagation of financial shocks. ${ }^{8}$ However, little is known of the linkages between the corporate saving glut and the current account in advanced economies. Finally, our findings are also related to Mian et al. (2017) who find a central role for the household debt in predicting future trade balances.

This paper has many policy implications, as a better understanding of the domestic implications of cross-border financial flows is essential for macroeconomic and financial stability (Obstfeld, 2012). Indeed, large and persistent external deficits can lead to the creation or amplification of domestic distortions, upward pressure on asset markets, fiscal and banking volatility but also to potential sudden stops in net flows and debt rollover problems (Lane, 2015). Large current account surpluses can also be problematic at a global level, as they have to be matched by a corresponding deficit, and at a domestic level, as they can reflect structural distortions (IMF, 2017). ${ }^{9}$ For instance, our findings suggest tackling distortions in the NFC and GOV sectors might be more likely to generate balanced current accounts than policies aimed at HH sector saving. Our analysis calls for a joint framework in analyzing global imbalances and sectoral flows.

The rest of this paper is structured in the following manner. First, we present the conceptual framework and review national accounts identities. Then, we shed light on the broad stylized facts and correlation patterns between sectors. In section 4, we present the empirical analysis of mediumterm covariates of the current account. Next, we examine the external adjustment since the crisis, and finally, we perform an event study investigating the contribution of sectoral balances to external episodes. Section 7 offers some conclusions and possible extensions.

\footnotetext{
${ }^{8}$ Our work is also linked to the literature on sectoral accounts, see Castren and Kavonius (2009), Behringer and van Treeck (2015) and Carvalho (2015). In particular, Behringer and van Treeck (2015) study the link between sectoral balances and the current account through the lens of a rise in inequality.

${ }^{9}$ This has been recognized by policymakers and regulators since the crisis, with the establishment in 2011 of the Macroeconomic Imbalance Procedure (MIP) to identify macroeconomic domestic imbalances in EU countries for instance.
} 


\section{Conceptual Framework}

Let's begin by taking a look at the basic concepts that will be used throughout this paper. ${ }^{10}$ Traditionally, the current account is decomposed into either the difference between exports and imports (and net foreign income) or the difference between saving and investment (e.g. Chinn and Prasad 2003). However, in recent years there has been an increase in the availability of sectoral balance sheet data in most advanced economies, allowing us to break down the current account balance into the sum of the net financial balances of the HH sector, the government, non-financial corporations, and the financial sector. ${ }^{11}$ As flows across domestic sectors cancel out in the aggregate, we have the following identity:

$$
C A_{i t}=N F B_{i t}^{H H}+N F B_{i t}^{G O V}+N F B_{i t}^{N F C}+N F B_{i t}^{F C}
$$

with the current account balance denoted $C A_{i t}$ and $N F B_{i t}^{s}$ is the net financial balance of sector (s) (HH: Households, GOV: Government, NFC: Non-Financial Corporations, FC: Financial Corporations). Improvements in the net financial balance of one sector will improve the current account balance, everything else equal.

Just like the current account at the aggregate level, the financial balance of each sector is equal to income minus total expenditures of that sector. In addition, the net financial balance of a sector can be derived as saving less investment (on the real side) or calculated as the difference between the net acquisition of financial assets and net incurrence of financial liabilities (on the financial side). Moreover, a financial surplus (a net lending or saver balance) indicates the sector is a net acquirer of financial assets, whereas a deficit (a net borrowing balance) indicates the sector is running down its financial assets (or increasing its borrowing) to fund its spending. Just like its external counterpart, there can also be sizable discrepancies between the real and the financial side. For this analysis, we use the net lending from the financial accounts.

Additionally, national accounts identities allow us to decompose the change between the net international investment position (NIIP) between $\mathrm{t}$ and $t-1$ in the following manner: ${ }^{12}$

$$
N I I P_{t}-N I I P_{t-1}=C A_{t}+S F A_{t}
$$

where $S F A_{t}$ is the Stock Flow Adjustment term, used as a proxy for revaluation changes. ${ }^{13}$

In turn, this allows us to decompose both the net international investment position and the

\footnotetext{
${ }^{10}$ For further information on sectoral financial accounts see OECD (2017).

${ }^{11}$ There exists discrepancies between the current account and the flows in the rest of the world accounts from the sector accounts. However, they are conceptually equivalent, see Appendix A for more details. We use the current account balance, but our findings are robust to using the rest of the world balance.

${ }^{12}$ We have $F A_{t}=-\left(C A_{t}+K A_{t}+E O_{t}\right)$. $F A_{t}$ is the financial account balance, $K A_{t}$ pertains to the capital account balance and $E O_{t}$ is the net errors and omissions. For simplicity, we assume $K A_{t}$ and $E O_{t}$ are equal to 0 .

${ }^{13}$ The Stock Flow Adjustment term is composed of a valuation term, the net capital gain on the existing holdings of foreign assets and liabilities, and a term capturing net other non-flow changes to the net international investment position (for example, due to changes in reporting methods and data revisions). See Curcuru et al. (2009) for further discussion on the importance of the net other statistical term.
} 
stock flow adjustment across domestic counterparts:

$$
\begin{aligned}
& N I I P_{i t}=N F P_{i t}^{H H}+N F P_{i t}^{G O V}+N F P_{i t}^{N F C}+N F P_{i t}^{F C} \\
& S F A_{i t}^{N I I P}=S F A_{i t}^{H H}+S F A_{i t}^{G O V}+S F A_{i t}^{N F C}+S F A_{i t}^{F C}
\end{aligned}
$$

with $N F P_{i t}$ is the Net Financial Position of each domestic sector (s) of the economy.

These decompositions will allow us to subsequently study the contributions of each sectoral balance to the current account, the covariation patterns between the standard set of fundamentals of the current account and sectoral balance, the international adjustment process since the crisis, and finally the patterns of sectoral balances during episodes of current account imbalances.

\section{Sectoral Balances and Global Imbalances}

This section describes the contribution of sectoral balances to the current account balance (the flow side) and of sectoral positions to the net international investment position (NIIP) (the stock side) from 1995 to $2015 .^{14,15}$ In addition to looking at our full sample of countries, we split the sample between current account deficit and surplus countries. ${ }^{16}$ Finally, we shed light on how each sectors' net transactions and holdings are associated with the current account and the NIIP respectively.

\subsection{Sectoral Contribution to the Current Account Balance}

Using the national account decomposition described above, Figure 1 shows the weighted average contribution of each sector to the current account balance in current account deficit and current account surplus economies. ${ }^{17}$

There are striking systematic differences in the patterns of the domestic counterpart of external balances in current account surplus and deficit countries. First, the size of the domestic sectoral balance, the counterparts of the current account, are considerably larger in deficit countries. This could reflect, in part, the increased financial integration, but also, country-specific demand booms in the run-up the crisis. Whereas the net lending balance of the HH sector experienced a similar decreasing trend in both sets of countries in the pre-crisis period, deficit countries have on average significantly larger GOV and NFC net borrowing balances.

Second, we see a large reduction in external imbalances in the aftermath the crisis in deficit countries (even large deficits persist in the United States and the United Kingdom). However,

\footnotetext{
${ }^{14}$ We use annual non-consolidated financial accounts compiled by Eurostat and the OECD. These accounts are based on ESA 2010 methodology.

${ }^{15}$ At the policy level, the G20 data gaps initiative in 2009 identified strengthening the availability of sectoral balance sheets as key to addressing the gaps in data revealed by the global financial crisis.

${ }^{16}$ Countries are split into surplus or deficit countries based on their current account balance in 2007, the eve of the global financial crisis, following IMF (2017). We also cumulate current account balances from 1995 to 2007 and find the same country split. This is a reduced sample in order to only take into account countries with data from 1995 to 2015. See Appendix B for list of countries.

${ }^{17}$ Figure D1 shows the unweighted sector contribution by country group. We see that the decreasing HH saving in the United States in the pre-crisis period, partly due to the house price boom, and the constant HH saving in Germany have a strong impact on the aggregate flows.
} 
significant surpluses remain, particularly in countries like Germany, the Netherlands, and Japan. Since the crisis, GOV deficits have appeared in surplus countries but they remain a lot smaller than in deficit countries. In addition, there was a large contraction in the NFC net borrowing balances in countries with current account deficits, mirroring the contraction in the external balance.

To get a clearer picture of the trends of each sectoral flow, Figure 2 shows the median flow of each sector. We see a clear difference in levels between current account surplus and deficit countries for the median NFC and GOV sectors flows. However, the dynamics are very similar for the $\mathrm{HH}$ and FC sectors, with similar post-crisis median values in both types of countries. In the aftermath of the crisis, the average balance of the GOV sector went from net surplus to net deficit in surplus counties. In deficit countries, the NFC sector reversed its large deficit, reaching similar median levels as current account surplus countries.

Finally, how do domestic financial balances correlate with the current account? Figure 3 shows there is a strong systematic positive relationship between the cumulated current account balance and the cumulated net financial balance of the NFC sector and the GOV sector. Indeed, larger cumulative net lending balances of the NFC and GOV sectors tend to go hand in hand with larger current account surpluses. Surprisingly, we can also note that there exists no such correlation pattern in relation to the FC and HH sectors. ${ }^{18}$ The sharp increase in corporate earnings, coupled with increasingly important roles for global firms and investors are possible explanations for these patterns (see Figure D2).

To summarize, even though current account imbalances have shrunk since the crisis, domestic imbalances have not. Moreover, there are systematic differences between the domestic counterpart of current account surpluses and deficits, mostly due to net lending balances in the NFC sector in surplus countries and net borrowing balances of the NFC and GOV sectors in deficit countries since the global financial crisis. Overall, there is no systematic relationship between the current account and the HH sector in the data, in stark contrast in the NFC and GOV sectors.

\subsection{Sectoral Contribution to the Net International Investment Position}

In relation to the domestic counterpart of the NIIP, the overall trends are more stable, with a general increase in external imbalances (Figure 4). ${ }^{19}$ The net external position improved to approximately 42 percent of GDP in surplus countries and deteriorated to around -61 percent of GDP in deficit countries in 2015. Overall, Table 1 shows that structurally the NFC sector tends to have large negative positions, the HH sector large positive positions, the GOV sector relatively smaller negative positions, and the FC sector approximately balanced positions.

Table 1 shows that current account deficit countries have systematically larger $\mathrm{HH}$ surplus positions and more negative NFC and FC deficit positions, with this pattern accentuating over

\footnotetext{
${ }^{18}$ However, it is important to bear in mind that a large portion of the household sector's net worth is in the form of non-financial assets not present in their financial net balance (mainly real-estate holdings). Allen (2017) shows that households' housing assets and capital gains have a strong negative association with changes in the external position, and particularly with the net international debt position.

${ }^{19}$ Figure D3 shows the unweighted sector contribution by country group. We see that the government (and external) position deteriorates due to less weight put on Norway's GOV surplus (and net external surplus) position.
} 
time. Interestingly, it is only since the global financial crisis that deficit countries also have more negative net GOV positions, with similar positions in 2002 and 2007.

We see that during the 2002-2007 period, the net position of the NFC sector deteriorated in our sample of both deficit and surplus countries (by 23.6 percentage points). However, from 2007 onwards, the net position improves in surplus countries (by 10 percentage points) and deteriorates in deficit countries (by 10 percentage points). Moving to the GOV sector, its net position rose between 2002 and 2007, only deteriorating slightly in deficit countries. However, it decreased by 32 percentage points from 2007 onwards, due to a large deterioration of its net position in deficit countries (it worsened by 46 percentage points in deficit countries and improved by 8 percentage points in surplus countries). Households' net position improved by 18 percentage points between 2002 and 2007 and 46 percentage points since 2007, due to a large accumulation of net assets in deficit countries (over 80 percentage points over the 2002-2015 period compared to a modest improvement of under 3 percentage points in surplus countries). Finally, the FC net position has improved by around 4 percentage points in both periods, with larger increases in deficit countries over the 2002-2007 period and in surplus countries post $2007 .^{20}$

In sum, even as net external flow imbalances have shrunk, net international position imbalances have expanded. The domestic counterpart of this expansion has been largely reflected in a deterioration of the NFC sector balance in all countries prior to 2008, and since then in a deterioration of the net position of the GOV and NFC sectors in deficit countries. The balance sheet of the HH sector has recovered significantly in deficit countries (largely due to valuation gains), but not enough to stop a deterioration of the external position. ${ }^{21}$

Building on these stylized facts, our empirical strategy is threefold. First, in the next section, we will present our econometric specification of medium-term covariates of the current account. We will examine how the net sectoral balances are associated with the set of macroeconomic fundamentals usually used in the literature to analyze the current account. In the following section, we will examine the contribution of sectoral balances in the international adjustment process in the aftermath of the global financial crisis. Finally, we will perform an event study investigating the dynamics of sectoral balances during significant and persistent current account surplus and deficit episodes.

\section{Sectoral Balances and the Covariates of the Current Account}

\subsection{Empirical Strategy}

As previously outlined, the first step in our empirical work is to revisit the question of the mediumterm covariates of external imbalances by analyzing the correlation patterns of a standard set of

\footnotetext{
${ }^{20}$ If we decompose the change in stock positions between flows (i.e. cumulated net balances) and stock-flow adjustments (i.e. valuation gains or losses), Figure D4 shows different patterns across time periods (the boom phase 2001-2007 and the crisis 2008-2013) and type of country. The striking finding of this figure is that changes in valuation are a lot larger than changes in flows.

${ }^{21}$ Figure D5 shows the association between the change in the net international investment position and the net financial wealth of the domestic sectors.
} 
macroeconomic fundamentals with the sectoral counterpart of current account balances. In order to accomplish this, we run the following panel OLS regressions with time fixed effects in the spirit of Chinn and Prasad (2003), Chinn and Ito (2007), Lane and Milesi-Ferretti (2012), and Phillips et al. (2013): ${ }^{22}$

$$
C A_{i t}=\alpha+\beta X_{i t}+\delta_{t}+\epsilon_{i t}
$$

For the conventional covariates of the current account, $X_{i t}$, we use the same macroeconomic fundamentals as in Lane and Milesi-Ferretti (2012). ${ }^{23}$ These variables include demographic factors (old age dependency ratio, aging speed, and population growth), GDP growth, the level of GDP per capita, the lagged net international investment position, and dummies for the global financial crisis and for financial centers. ${ }^{24}$ However, contrary to Lane and Milesi-Ferretti (2012), we do not add the fiscal balance, to be able to compare the explanatory power of the fundamentals across all sectors, including the GOV sector itself. ${ }^{25}$ Likewise, for the balance of each sector (s) (HH: Households, GOV: Government, NFC: Non-Financial Corporations, FC: Financial Corporations) we have:

$$
N F B_{i t}^{s}=\alpha^{s}+\beta^{s} X_{i t}+\delta_{t}^{s}+\epsilon_{i t}^{s}
$$

Our dependent variable $N F B_{i t}$ is the Net Financial Balance of each institutional sector of the economy. As mentioned above, the net financial balance of a sector can be derived as saving less investment or as the difference between the net acquisition of financial assets and net incurrence of financial liabilities. In addition, the sum of the domestic net financial balance equals the current account of the economy as a whole. In our main specification, we average the net flows in 3-year non-overlapping periods to smooth business-cycle fluctuations. ${ }^{26}$ In a similar vein to the previously cited literature, we do not include country fixed effects, as they would remove a lot of the variation we are interested in explaining.

\subsection{Econometric Results}

Table 2 presents our results for the estimation of equations (5) and (6). Column (1) shows the regression for the current account; in columns (2)-(5), we repeat the analysis for the net financial balance of each domestic sector. We find that the aggregate patterns are not shared across all sectors, and, in particular, we find a surprisingly limited role for the $\mathrm{HH}$ sector. Indeed, the traditional covariates of the current account explain a large share of the net balances of the GOV

\footnotetext{
${ }^{22}$ As a robustness check, we run OLS estimations on two-year and four-year averaged data and as well as annual data with similar results. We also run Seemingly Unrelated Regressions (SUR) with similar results (available upon request).

${ }^{23}$ As a robustness test, we also use the macro covariates used by Chinn (2017) and the IMF External Balance Assessment (EBA-lite) without changing our main findings.

${ }^{24}$ The dependency ratio is the ratio of the population over 65 years old relative to the working age population (between 30 and 64 years old). Aging speed is determined as the difference between the expected old age dependency ratio in $\mathrm{t}+20$ and the old age dependency ratio in t. See the Data Appendix for more details.

${ }^{25}$ In the appendix, we also add the lagged fiscal balance and the patterns stay the same.

${ }^{26} \mathrm{It}$ is important to note that the aggregate results on the current account might not necessarily be identifiable at the sectoral level as these sectors covary between themselves.
} 
and the NFC sector, however, they explain relatively little of the $\mathrm{HH}$ and FC sectors balances. We also find some covariates have interesting offsetting and reinforcing effects between sectors.

In terms of overall explanatory power, the set of fundamental covariates explain 57 percent of the current account balance. This result is reflected in the GOV and NFC sectors' balances, where fundamentals explain 49 and 37 percent of the respective variation. Next comes the HH sector with 25 percent and the FC with a mere 5 percent.

Regarding the current account regression column (1), GDP per capita, GDP growth, population growth, and the crisis and financial center dummies are all statistically significant. GDP per capita, which can be used as a proxy for the marginal product of capital, has its expected positive sign. GDP growth is significant and negative, in line with the literature. Population growth comes into play significantly and is associated with a deterioration of the current account as expected. ${ }^{27}$

Turning our attention to the net financial balance of the domestic sectors given by columns (2)-(5), we see that the conventional determinant of the current account can have offsetting or reinforcing effects across sectors. The GOV balance is pro-cyclical (it is positively associated with GDP growth), whereas the NFC balance is counter-cyclical, with the latter effect dominating on the current account. For GDP per capita, there is a positive association with the GOV balance (in line with its effect on the current account), however, it is associated with a deterioration of the $\mathrm{HH}$ sector balance.

However, the effects of population growth on the GOV and FC sector balances supplement each other and account for the strong overall negative association with the current account. The other demographic variables (the dependency ratio and aging speed) effectively cancel each other out in the aggregate. Old age dependency is positively associated with the $\mathrm{HH}$ balance but negatively correlated to the GOV and NFC sectors. This is somewhat surprising, as it is included to capture the effect of retirees drawing down their savings. Aging speed is strongly associated with improvements in the net balance of the NFC sector, counterbalancing its negative co-movement with the GOV balance. The lagged net international investment position has a significant influence on the $\mathrm{HH}$ sector balance, but not the others. Finally, the financial center dummy is associated with an improvement in the current account, the HH sector balance, and the NFC balance. However, it is associated with a deterioration of the GOV balance.

These patterns are robust to different lists of macroeconomic covariates. Using the same medium term covariates of the current account as Chinn (2017) and applying our methodology, we find very similar results (see Table D5). In addition, if we include the lag of the fiscal balance (omitted for sake of comparability across sectors), Table D3 shows the patterns stay the same (with an increase in the fit for the GOV sector). In addition, if we use the IMF's list of covariates from its EBA-lite methodology (IMF, 2016), the results are very similar in terms explanatory power across sectors (see Table D4).

However, there are other ways one could assess current account balances through sectoral balances. For instance, one could explain each balance with a set of fundamentals specific to each

\footnotetext{
${ }^{27}$ Additionally, we break down the net lending of each sector into saving and investment flows (see Table D2 for the results).
} 
sector (see IMF (2017)). However, given our ultimate focus on deepening our understanding of the current account, we will limit our scope to the standard set of covariates of the current account in this paper.

The main lessons of these findings are that the aggregate results linking a set of fundamental to the medium-term movements in the current account do not translate across the domestic counterparts of the current account. In fact, there is a striking difference in overall explanatory power across sectors. These covariates explain the bulk of the variation of the NFC and GOV sector financial balances. However, it is not the case for the $\mathrm{HH}$ sector, the sector at the source of many traditional theoretical models and narratives of the current account. The association with the FC is particularly low, most likely due to its intermediation role. In addition, while we do find interesting offsetting dynamics between some sectors, it is not systematically the case that the HH sector offsets decisions of the NFC or the GOV sector. This evidence suggests households do not fully pierce the "corporate veil" and corroborates the failure of Ricardian equivalence.

\section{Sectoral Balances and the External Adjustment since the Crisis}

In this section, we take a fresh look at the patterns linking pre-crisis imbalances and the subsequent adjustment of the current account since the global financial crisis, drawing on Lane and MilesiFerretti $(2012,2015)$. However, here we study these linkages through the lens of domestic sector balances.

The key insights from this section are that the lion's share of the adjustment of the current account in the aftermath of the crisis can be accounted for by lower pre-crisis NFC net balances and larger post-crisis NFC adjustments. The post-crisis improvements in the NFC are consistent with the narrative of an external adjustment operating primarily through decreasing investment as opposed to increasing saving. Finally, these patterns are even more pronounced in countries running pre-crisis current account deficits in excess of the values indicated by their underlying fundamentals (i.e. negative "gap" countries). Because we are looking at a more recent time period, we can extend our sample of countries. ${ }^{28}$

We proceed in three steps. First, we examine how pre-crisis sectoral balances can account for the adjustment process of the current account in the aftermath of the crisis. Second, we study the post-crisis adjustment channels. In other words which sector adjusted as a counterpart of the current account rebalancing. Finally, after defining the pre-crisis current account gap as deviations of the observed current account from the balance explained by a set of fundamental, we show that there is striking cross-country variation in both pre and post-crisis dynamics of the domestic sectors depending on whether the country was running an excessive current account balance or not in the run-up to the crisis. We focus on predetermined variables in our regressions to limit the endogeneity issues in interpreting our results. Our approach does not allow us to take a stand on the underlying causal mechanisms, but to identify through which sector the aggregate adjustment of the current account took place.

\footnotetext{
${ }^{28}$ See Appendix B for the list of countries.
} 
As a first glance at the data, Figure 5 shows the bivariate relationship between the adjustment of the current account since 2008 (i.e. the change between the average current account balance between 2005-2008 and its 2015 value) and the pre-crisis average balance between 2005-2008 for the current account and each domestic sector. ${ }^{29}$ We see that the correlation is clearly negative and very strong between the post-crisis adjustment and the pre-crisis current account balance. This negative association is reflected in the pre-crisis NFC and GOV balances. Countries with the largest precrisis net deficits in these sectors tend to have larger current account adjustments in the aftermath of the crisis. The relationship is a lot weaker for the HH and FC sectors. However, we do not see any striking differences between pegged and non-pegged economies.

Next, we look at this relationship while taking into account the initial level of the NIIP. Indeed, following Lane and Milesi-Ferretti (2015), increased pressure to adjust could have been placed on countries with high levels of outstanding net international liabilities. In order to control for this, first, we perform the simple following cross-sectional regression:

$$
\Delta C A_{i, 0508-15}=\alpha+\beta C A_{i, 0508}+\gamma N I I P_{i, 0407}+\epsilon_{i}
$$

$\triangle C A_{i, 0508-15}$ is the adjustment of the current account balance, $C A_{i, 0508}$ is the average current account balance the 2005-2008 period, and $N I I P_{i, 0407}$ is the average stock of net international assets over the 2004-2007 period. The regression results are shown in Table 3, column (1). As expected, a larger pre-crisis current account deficit is associated with a larger post-crisis adjustment.

In order to see how this aggregate result is distributed across domestic sectors, we replace the pre-crisis current account balance with the domestic sectoral net balances, denoting $N F B_{i, 0508}^{s}$ the average balance of sector (s) (HH, GOV, NFC, and FC):

$$
\Delta C A_{i, 0508-15}=\alpha+\sum_{s} \beta^{s} N F B_{i, 0508}^{s}+\gamma N I I P_{i, 0407}+\epsilon_{i}
$$

It is the pre-crisis net financial balance of the NFC sector that is most significantly correlated with the current account adjustment (column (2)). The HH and GOV sectors are also negatively associated with the adjustment but at lower significance levels.

Pushing further, we ask if conditional on the pre-crisis current account imbalance, do sector balances give any additional information on the post-crisis adjustment of the current account? Following Lane and Milesi-Ferretti (2015), we derive a measure of current account imbalances, called the current account gap, as the difference between the observed current account from the balance explained by a set of fundamentals in the pre-crisis period. ${ }^{30}$ To see this, we run the following cross-sectional regression:

$$
\Delta C A_{i, 0508-15}=\alpha+\beta N F B_{i, 0508}^{s}+\delta G A P_{i, 0508}+\gamma N I I P_{i, 0407}+\epsilon_{i}
$$

\footnotetext{
${ }^{29}$ We omit the extreme cases of Iceland, Norway, and Bulgaria for the following analysis.

${ }^{30}$ To derive the current account balance explained by fundamentals, we run the regression $C A=C A\left(X_{i t}\right)$ over the 1970-2015 period with 4-year non-overlapping averages. $X_{i t}$ corresponds to the controls used in table 2 . The current account gap is then computed as follows: $C A^{\text {gap }}=C A^{\text {observed }}-C A^{\text {predicted }}$. The results of the regression are in line with Lane and Milesi-Ferretti (2012) and are available upon request.
} 
The results of this regression are column (4)-(7). They show that only the net pre-crisis balance of the NFC sector is a robust predictor of the post-crisis external adjustment, even controlling for the pre-crisis current account gap. Given the gap, larger net deficits in the NFC sector are associated with a larger correction in the current account balance. ${ }^{31}$

In order to see through which channels the adjustment of the current account took place, we look at the relationship between the current account gap and the subsequent adjustment of the domestic sectors since the crisis (i.e. the change between the average sector balance between 2005-2008 and its 2015 value), by running the following regression: ${ }^{32}$

$$
\Delta N F B_{i, 0508-15}^{s}=\alpha+\beta G A P_{i, 0508}+\gamma N I I P_{i, 0407}+\epsilon_{i}
$$

Column (1) of Table 4 shows that the pre-crisis gap accounts for a large portion of the current account adjustment since the crisis. This aggregate result is only reflected in the NFC sector, column (4), where the pre-crisis current account gap explains a similar share of the post-crisis adjustment of the NFC sector. Countries with more negative gaps have experienced a larger adjustment in their current account and NFC balance. This is consistent with the narrative of an external adjustment achieved mainly through decreasing investment as opposed to decreasing consumption. ${ }^{33}$

Next, we examine the striking difference in patterns between countries with positive or negative pre-crisis current account gap values. ${ }^{34}$ Indeed, a symmetric adjustment between positive and negative gap countries seems unlikely, as sustainability constraints in excess deficit countries do not necessarily have a counterpart in excess surplus countries. Figure 6 shows the stark contrast in average net flows in the pre-crisis period and post-crisis adjustments when we split the sample. ${ }^{35}$ The average pre-crisis sectoral flows were smaller in current account gap countries, most noticeably for the NFC and GOV sectors. Moreover, the post-crisis adjustment in all sectors was notably larger in negative current account gap countries, in particular for the NFC sector with an average adjustment of over 8 percent of GDP in negative gap countries against under 4 percent in positive gap countries. Evidently, it is difficult to infer much regarding the underlying causal mechanisms from our approach, however, we can speak to which sector's balance can account for the aggregate patterns we see for the current account.

In summary, the large adjustment in current account balances seen in the aftermath of the global financial crisis is largely accounted for by NFC sector net flows, consistent with the narrative of declines in investment. These patterns have striking differences between countries with pre-crisis

\footnotetext{
${ }^{31}$ Moreover, there was also a large within sector adjustment since the crisis, with all sectors undergoing a correction of their net lending balance (see Figure D6). The adjustment of the government sector was the strongest, unsurprisingly followed by the NFC sector.

${ }^{32}$ One could also compute sectoral gaps. However, given our limited timeframe and our primary focus on the current account, we do not perform those regressions.

${ }^{33}$ Additionally, Figure D7 shows the contemporaneous post-crisis adjustment of the current account and the sector balances. Clearly, we cannot infer any causal link as the variables are jointly determined. However, we do see that there is a strong association between the current account adjustment and the NFC and GOV sectors. The relationship is less clear for the $\mathrm{HH}$ and FC sectors.

${ }^{34}$ After taking the difference between the actual and predicted pre-crisis current account, we find sub-samples of countries with positive and negative gaps, see Appendix B for country list.

${ }^{35}$ We drop Iceland as the extreme nature of the build-up of its financial sector skews the cross-country average.
} 
positive or negative current account gaps (measured as the difference between the observed current account and the level predicted by fundamentals), with adjustments in every sector substantially larger in the negative gap countries. In both sets of countries, the bulk of the adjustment occurred in the NFC sector, however, the HH sector also increased its net lending balance in negative gap countries. These findings are consistent with the expenditure reduction explanation of current account reversals, with most of the adjustment occurring on the investment side (mainly due to the NFC sector) as opposed to the consumption side (mainly due to the HH sector). ${ }^{36}$

\section{Sectoral Balances During Large External Imbalances}

In our preceding analysis, we looked at the domestic counterpart of current account covariates and adjustments. In this section, we will examine periods of large and persistent capital inflows (or current account deficits) and outflows (or current account surpluses) and document the sectoral patterns that lie behind them. This allows us gain insights for a comprehensive assessment of external sustainability, by highlighting which sector accumulates wealth or builds-up liabilities, but also by determining if imbalances are dominated by private flows or public flows. ${ }^{37}$ Ultimately, the key takeaway is that there is very little difference between large and persistent surplus and deficit episodes when it comes to the HH sector. There are stark differences for the GOV, NFC, and FC sectors.

Simply defining large current imbalances as balances over 3 percent of GDP in absolute value in one year, a first glance at the data shows that $\mathrm{HH}$ balances show no differential patterns between large surpluses and deficits. Table 5 shows that the average net financial balance during years with current account imbalances, varies from surplus to deficits from 0.6 to -3.8 for the GOV, 0.5 to -4.9 for the NFC, 1.3 to -4.8 percent of GDP for the FC sector. However, it only varies from 3.2 to 2 percent of GDP for the HH sector.

In order to capture persistent episodes of imbalances, we combine imbalances of a least five consecutive years into episodes. Tables 6 and 7 show the full list of the episodes. ${ }^{38}$ Figure 7 shows the median contribution of sector flows to the change in current account balance over an 11-year window (year 0 marks the beginning of the episode). The HH sector accumulated similar financial surplus between 22 and 30 percent of GDP during large deficits and surpluses respectively. In stark contrast, flows in the other domestic sectors differed considerably during surplus and deficit episodes. The NFC and FC sectors accumulated net surpluses of under 20 percent of GDP during surplus periods, whereas during deficits, the FC sector has had a roughly balanced flows and the NFC sector accumulated net deficits around -60 percent of GDP. The GOV sector has accumulated a small net deficit during surplus episodes and net deficits of around -60 percent of GDP during

\footnotetext{
${ }^{36}$ Looking at the breakdown between gross financial assets and liabilities, Figure D8 highlights the key role of the FC sector.

${ }^{37}$ In a similar manner to Forbes and Warnock (2014) determine equity and debt-led episodes.

${ }^{38}$ The sudden stop literature defines episodes as deviations from long-run trends, see Benigno et al. (2015) for instance. The rationale is that if a country can sustain current account deficits of $\mathrm{x}$ percent, then it is the deviations from these trends that matter. However, this is not this paper's objective. We look at what happens to sector balances during large and persistent deficits and surpluses.
} 
deficits. ${ }^{39}$

However, when we turn to the change in stock positions during these episodes, the story changes. Figure 8 shows the median change in net financial wealth during these same episodes. During deficit episodes, the $\mathrm{HH}$ sector has surprisingly accumulated roughly no net financial wealth in contrast to cumulated flows of around 20 percent of GDP. This is due to negative valuation adjustments over the period. The external sector accumulated liabilities of around 50 percent of GDP, with the NFC and GOV sectors contributing equally. During surplus episodes, the accumulation of foreign wealth followed an accumulation of wealth in the GOV and HH sectors of around 20 percent of GDP, with the FC's position not changing (reflecting some negative valuation effects). The NFC sector, however, has experienced negative wealth changes during the episode. However, this may reflect the increasing price of equity shares on the liability side of their balance sheet. ${ }^{40,41}$

Going further into the country by country differences, Table 6 and 7 show the adjustment of the main sectors during surplus and deficit episodes. We see that even within current account episodes, there are considerable differences in their sectoral decomposition. In the spirit of Forbes and Warnock (2014) we classify the episodes simply in two categories: publicly-led episodes (G) and privately-led episodes $(\mathrm{P})$. We do this by looking at the sum of net balance for the private sector (adding HH, NFC, and FC) over the period of time the episode lasts, comparing it to the public sector net balance and assigning the episode to the sector with the largest flow. Table 6 shows that in current account deficit episodes, the public sector adjustment is larger in 14 out of the 19 episodes and the private sector in the remaining 5 cases. Interestingly, Greece and Portugal both had public $(\mathrm{G})$ current account deficit episodes while Estonia had a private current account episode for instance, based on this methodology. However, for the current account surplus episodes, most episodes were associated with larger flows in the private sector, with 9 of the 11 episodes dominated by private sector flows and 2 were public sector driven (Table 7). For instance, for most of the sample, the Netherlands and Norway had current account surplus episodes, however private flows dominated in the former and public flows in the latter.

In sum, analyzing domestic balances during large and persistent current account episodes gives us insight into which sector has accumulated net wealth or net liabilities. In terms of flows, the $\mathrm{HH}$ sector balance is relatively similar in both types of episodes, with most of the accumulation of wealth during surplus episodes going to the NFC and FC sector and most of the build-up in liabilities during deficit episodes is in the GOV and NFC sectors. Interestingly, even within current account episodes, the domestic flows behind the episode can be very different. In terms of magnitude, cumulated private flows dominate public flows during surplus episodes in most countries, whereas public flows are larger during deficit episodes.

\footnotetext{
${ }^{39}$ Figure D9 and Figure D10 show the individual sectoral flows with error bands.

${ }^{40}$ Figure D11 and Figure D12 show the individual sectoral positions with error bands.

${ }^{41}$ The outstanding equity of a corporation is treated as a liability in the national accounts. In times of high stock price appreciation, this can lead to decreasing net financial wealth of the NFC sector. We can derive a modified NFP of the NFC sector by excluding the outstanding equity at market prices to get a measure of wealth which ultimately belongs to the shareholders.
} 


\section{Concluding Remarks}

In this paper, we have sought to better understand global imbalances and external adjustments in advanced countries by analyzing their domestic sectoral counterpart.

Our main findings shed light on a rather limited role for the $\mathrm{HH}$ sector in explaining these trends, in stark contrast to the NFC and GOV sectors. These findings are somewhat at odds with the widespread narrative that the HH sector plays a central role in current account dynamics. These results hold for: (i) the contribution of domestic balances to current account imbalances; (ii) the comovement with a widely-used set of medium-run covariates of the current account; (iii) the external adjustment in the aftermath of the global financial crisis; and (iv) the dynamics of domestic flows during large and persistent current account imbalance episodes.

For instance, there are systematic differences in the patterns of the domestic counterpart of external balances in current account surplus and deficit countries. This is largely due to the NFC sector net surplus in surplus countries in the past few decades and net deficits of the GOV sector in deficit countries since the global financial crisis.

Moreover, there is a striking difference between domestic balances in the overall explanatory power of the standard set of macroeconomic fundamentals commonly used as covariates of the current account. These variables explain the bulk of the variation of the NFC and GOV sector financial balances. This is not the case for the $\mathrm{HH}$ sector, at the source of many traditional theoretical models and narratives of the current account. Moreover, these fundamentals can sometimes have some interesting offsetting effects between domestic sectors, however, there is no evidence of the HH sector perfectly offsetting changes in the NFC or GOV sector, pointing to distortions and the presence of a "corporate veil" or non-Ricardian behavior.

Similarly, the NFC sector accounts for most of the correlation patterns between prior current account balances and the resulting adjustment process, with the $\mathrm{HH}$ sector playing a very limited role once again. These patterns are driven by countries with negative pre-crisis current account gaps (measured as the difference between the observed current account and the level predicted by fundamentals), with adjustments substantially larger for every sector in these countries. These findings are consistent with an expenditure reduction explanation of current account reversals, with most of the adjustment occurring on the investment side (mainly due to the NFC sector) as opposed to the consumption side (mainly due to the $\mathrm{HH}$ sector).

Finally, when we analyze domestic balances during episodes of capital inflows and outflows, we find that in terms of flows, the HH sector balance is relatively similar in both types of episodes, with most of the accumulation of wealth during surplus episodes going to the NFC and FC sector and most of the build-up in liabilities during deficit episodes in the GOV and NFC sectors. In addition,

private flows dominate public flows during surplus episodes in most countries, whereas public flows are larger during deficit episodes.

The results suggest that there are valuable insights to be obtained from integrating domestic sectoral balance into the analysis of global imbalances. We argue that models trying to understand external imbalances and adjustments should take into account the diverging patterns between the 
NFC and $\mathrm{HH}$ sectors saving and investment dynamics. On the policy side, tackling potential distortions on in the NFC sector, with regards to its funding mechanisms for instance, might be more likely to generate balanced current accounts than policies aimed at the HH sector. However, our paper still leaves open a series of important questions. In particular, there is little consensus on the underlying sources of the shift of the NFC sector towards becoming a net lender of funds and the sector's relationship with the rest of the world. This raises interesting challenges for future research. 


\section{References}

Adler, Gustavo and Garcia-Macia, Daniel. The Stabilizing Role of Net Foreign Asset Returns. IMF Working Papers 18/79, International Monetary Fund, April 2018.

Alfaro, Laura, Kalemli-Ozcan, Sebnem, and Volosovych, Vadym. Sovereigns, upstream capital flows, and global imbalances. Journal of the European Economic Association, 12(5):1240-1284, 2014.

Allen, Cian. Household wealth and the net international investment position. Mimeo, 2017.

Allen, Cian. Retained Earnings and Global Imbalances. Mimeo, 2018.

Aoyagi, Chie and Ganelli, Giovanni. Unstash the cash! corporate governance reform in japan. Journal of Banking and Financial Economics, 1(7):51-69, 2017.

Avdjiev, Stefan, Hardy, Bryan, Kalemli-Ozcan, Sebnem, and Servén, Luis. Gross Capital Flows by Banks, Corporates and Sovereigns. NBER Working Papers 23116, National Bureau of Economic Research, Inc, January 2017.

Avdjiev, Stefan, Everett, Mary, Lane, Philip R, and Shin, Hyun Song. Tracking the international footprints of global firms. BIS Quarterly Review, March 2018.

Bacchetta, Philippe and Benhima, Kenza. The Demand For Liquid Assets, Corporate Saving, And International Capital Flows. Journal of the European Economic Association, 13(6):1101-1135, December 2015.

Bayoumi, Tamim, Tong, Hui, and Wei, Shang-Jin. The Chinese Corporate Savings Puzzle: A Firm-level Cross-Country Perspective. In Capitalizing China, NBER Chapters, pages 283-308. National Bureau of Economic Research, Inc, 2012.

Behringer, Jan and van Treeck, Till. Income distribution and the current account: a sectoral perspective. Working Papers 379, ECINEQ, Society for the Study of Economic Inequality, October 2015.

Benigno, Gianluca, Converse, Nathan, and Fornaro, Luca. Large capital inflows, sectoral allocation, and economic performance. Journal of International Money and Finance, 55(C):60-87, 2015.

Blanchard, Olivier. Current Account Deficits in Rich Countries. IMF Staff Papers, 54(2):191-219, June 2007.

Calvo, Guillermo A., Izquierdo, Alejandro, and Mejia, Luis-Fernando. On the empirics of Sudden Stops: the relevance of balance-sheet effects. Proceedings, (Jun), 2004.

Carvalho, Daniel. Sectoral balance sheets, leverage and pro-cyclicality. PhD Dissertation, 2015.

Castren, Olli and Kavonius, Ilja Kristian. Balance Sheet Interlinkages and Macro-Financial Risk Analysis in the Euro Area. Working Paper Series 1124, European Central Bank, December 2009. 
Cerutti, Eugenio M and Hong, Gee Hee. Portfolio Inflows Eclipsing Banking Inflows: Alternative Facts? IMF Working Papers 18/29, International Monetary Fund, February 2018.

Chen, Peter, Karabarbounis, Loukas, and Neiman, Brent. The global rise of corporate saving. Journal of Monetary Economics, 89(C):1-19, 2017.

Chinn, Menzie. The Once and Future Global Imbalances? Interpreting the Post-Crisis Record. $K C$ Fed Jackson Hole Symposium "Fostering a Dynamic Global Economy, August 24-26 2017.

Chinn, Menzie and Ito, Hiro. Current account balances, financial development and institutions: Assaying the world "saving glut". Journal of International Money and Finance, 26(4):546-569, 2007.

Chinn, Menzie D. and Prasad, Eswar S. Medium-term determinants of current accounts in industrial and developing countries: an empirical exploration. Journal of International Economics, 59(1): 47-76, January 2003.

Curcuru, Stephanie E., Thomas, Charles P., and Warnock, Francis E. Current Account Sustainability and Relative Reliability. In NBER International Seminar on Macroeconomics 2008, NBER Chapters, pages 67-109. National Bureau of Economic Research, Inc, January 2009.

Falato, Antonio, Kadyrzhanova, Dalida, and Sim, Jae. Rising Intangible Capital, Shrinking Debt Capacity, and the US Corporate Savings Glut. Technical report, 2013.

Fan, Jingting and Kalemli-Ozcan, Sebnem. Emergence of Asia: Reforms, Corporate Savings, and Global Imbalances. IMF Economic Review, 64(2):239-267, June 2016.

Forbes, Kristin J. and Warnock, Francis E. Debt-and Equity-Led Capital Flow Episodes. In D., Miguel Fuentes, Raddatz, Claudio E., and Reinhart, Carmen M., editors, Capital Mobility and Monetary Policy, volume 18 of Central Banking, Analysis, and Economic Policies Book Series, chapter 9, pages 291-322. Central Bank of Chile, October 2014.

Galstyan, Vahagn, Lane, Philip R., Mehigan, Caroline, and Mercado, Rogelio. The holders and issuers of international portfolio securities. Journal of the Japanese and International Economies, 42(C):100-108, 2016.

Gourinchas, Pierre-Olivier and Rey, Helene. International financial adjustment. Journal of Political Economy, 115(4):665-703, 2007.

Gruber, Joseph W. and Kamin, Steven B. The Corporate Saving Glut and Falloff of Investment Spending in OECD Economies. IMF Economic Review, 64(4):777-799, November 2016.

IMF. Methodological Note on EBA-Lite. Policy Papers, 2016.

IMF. External sector report. Technical report, 2017. 
Koo, Richard C. Balance sheet recession as the "other half" of macroeconomics. European Journal of Economics and Economic Policies: Intervention, 10(2):136-157, 2013.

Lane, Philip R. Risk Exposures in International and Sectoral Balance Sheet Data. World Economics, 16(4):55-76, October 2015.

Lane, Philip R. and Milesi-Ferretti, Gian Maria. External adjustment and the global crisis. Journal of International Economics, 88(2):252-265, 2012.

Lane, Philip R. and Milesi-Ferretti, Gian Maria. Global Imbalances and External Adjustment After the Crisis. In Raddatz, Claudio, Saravia, Diego, and Ventura, Jaume, editors, Global Liquidity, Spillovers to Emerging Markets and Policy Responses, volume 20 of Central Banking, Analysis, and Economic Policies Book Series, chapter 4, pages 105-142. Central Bank of Chile, April 2015.

McCauley, Robert Neil, Benetrix, Agustin S, McGuire, Patrick, and von Peter, Goetz. Financial deglobalisation in banking? BIS Working Papers 650, Bank for International Settlements, June 2017.

Mendoza, Enrique G. Sudden stops, financial crises, and leverage. American Economic Review, 100 (5):1941-66, December 2010.

Mian, Atif, Sufi, Amir, and Verner, Emil. Household debt and business cycles worldwide. The Quarterly Journal of Economics, 132(4):1755-1817, 2017.

Milesi-Ferretti, Gian Maria and Razin, Assaf. Current account reversals and currency crises: Empirical regularities. In Currency Crises, pages 285-323. National Bureau of Economic Research, Inc, 2000.

Obrzut, Rober. Consistency between national accounts and balance of payments statistics. Review of National Accounts and Macroeconomic Indicators (EURONA), 2016.

Obstfeld, Maurice. Does the Current Account Still Matter? American Economic Review, 102(3): 1-23, May 2012.

Obstfeld, Maurice and Rogoff, Kenneth. The intertemporal approach to the current account. In Grossman, G. M. and Rogoff, K., editors, Handbook of International Economics, volume 3 of Handbook of International Economics, chapter 34, pages 1731-1799. Elsevier, January 1995.

OECD. Understanding Financial Accounts. 2017.

Phillips, Steven T, Catao, Luis, Ricci, Luca A, Bems, Rudolfs, Das, Mitali, Giovanni, Julian Di, Unsal, Filiz D, Castillo, Marola, Lee, Jungjin, Rodriguez, Jair, and Vargas, Mauricio. The External Balance Assessment (EBA) Methodology. IMF Working Papers 13/272, International Monetary Fund, December 2013.

Poterba, James M. Tax Policy and Corporate Saving. Brookings Papers on Economic Activity, 18 (2):455-516, 1987. 
Turrini, Alessandro and Zeugner, Stefan. Benchmarks for net international investment positions. Mineo, 2018.

Zetlin-Jones, Ariel and Shourideh, Ali. External financing and the role of financial frictions over the business cycle: Measurement and theory. Journal of Monetary Economics, 92(C):1-15, 2017. 
Figure 1: Sectoral Contribution to Current Account Balances

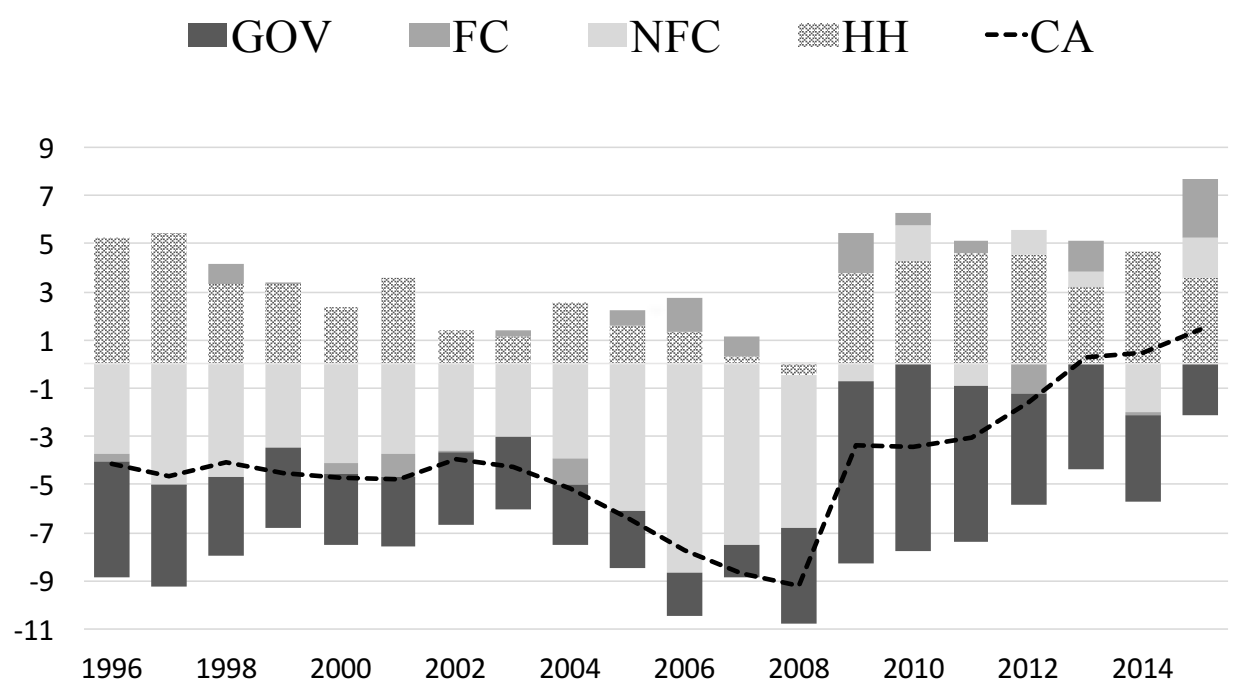

(a) Deficit Countries

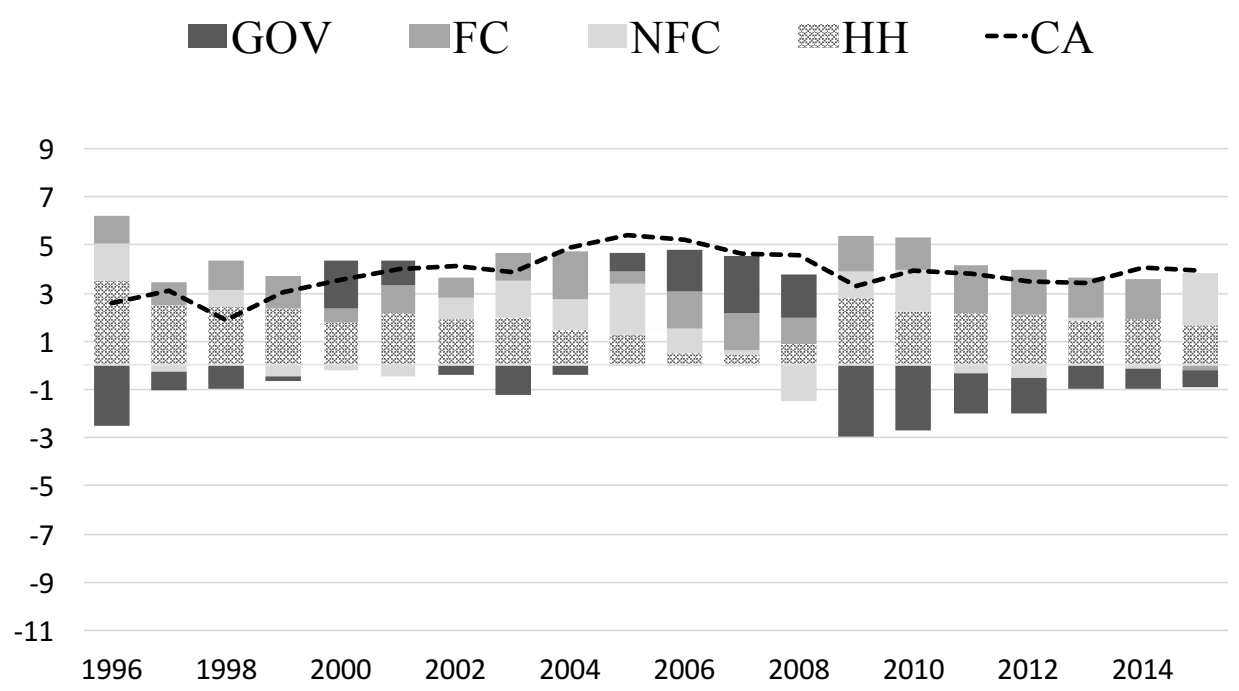

(b) Surplus Countries

Note: Average values of sectoral net financial balances and the current account balance, weighted by country GDP. GOV: Government, FC: Financial Corporations, NFC: Non-Financial Corporations, HH: Households, CA: Current Account. Current account surplus countries are: France, Belgium, Sweden, the Netherlands, Canada, Denmark, Norway, Germany, Finland, Austria, and Japan. Current account deficit countries are: Portugal, Cyprus, the United Kingdom, Lithuania, Spain, Greece, Czech Republic, Hungary, the United States, Slovak Republic, Italy, and Estonia. 
Figure 2: Domestic Sectoral Flows

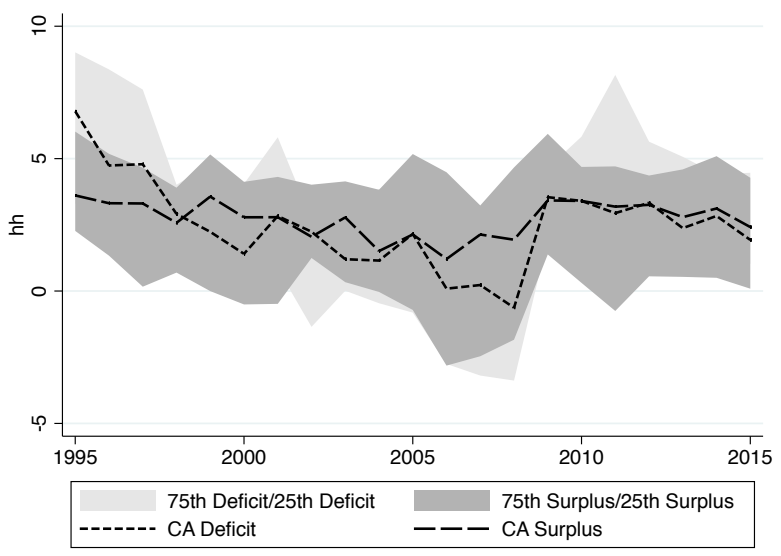

(a) $\mathrm{HH}$

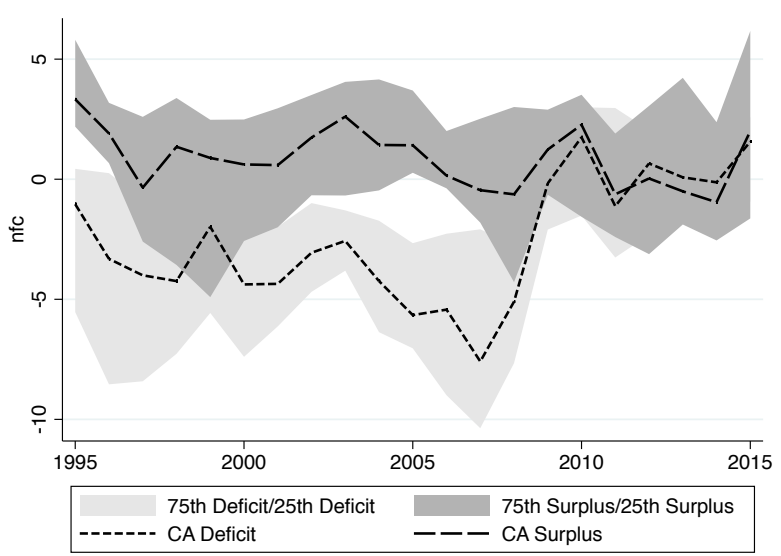

(c) NFC

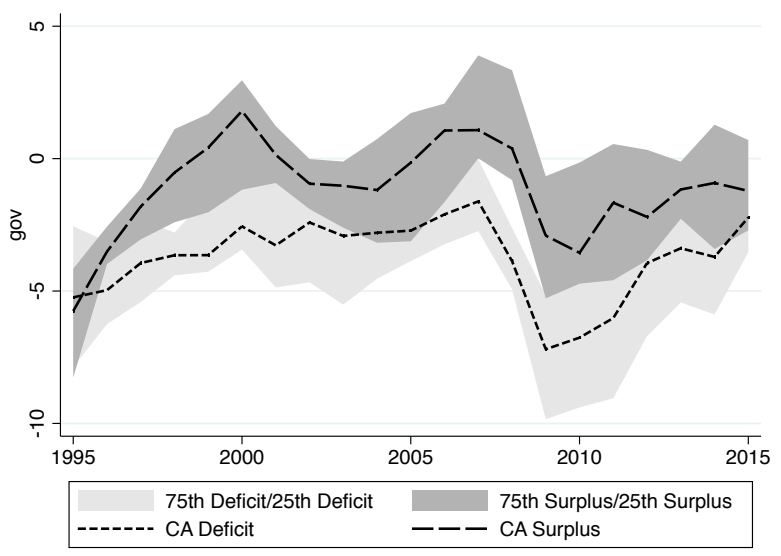

(b) GOV

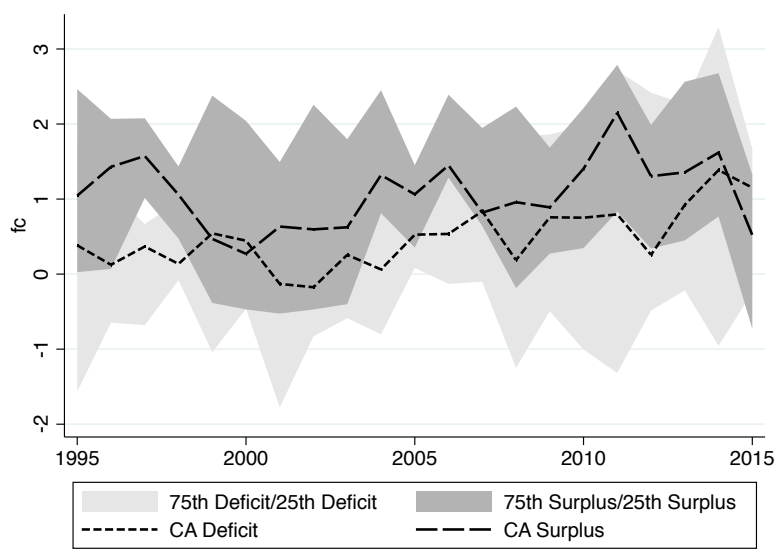

(d) FC

Note: In percent of GDP. Sectoral flows depending on if the economy was running a current account deficit or surplus on the eve of the crisis in 2007. Median values with error bands at the 25th and 75th percentile. GOV: Government, FC: Financial Corporations, NFC: Non-Financial Corporations, HH: Households. 
Figure 3: Cumulative Flows: Current Account and Across Domestic Sectors

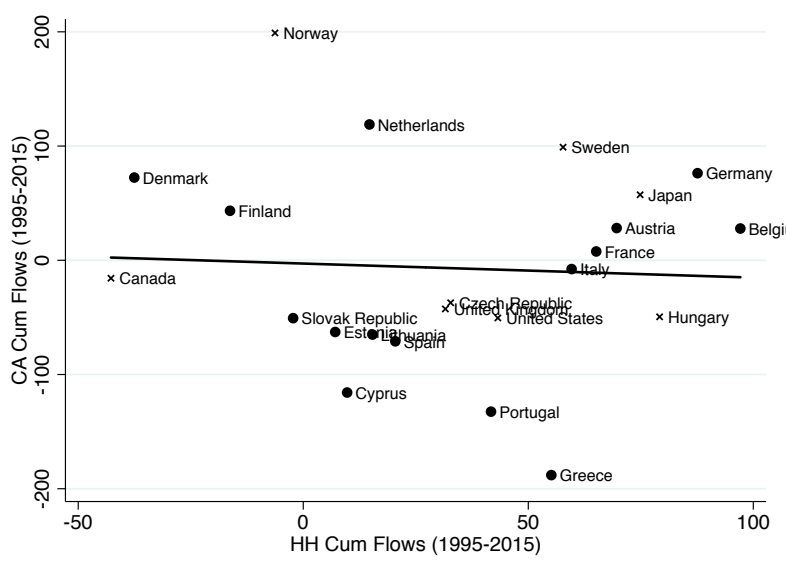

(a) $\mathrm{HH}$

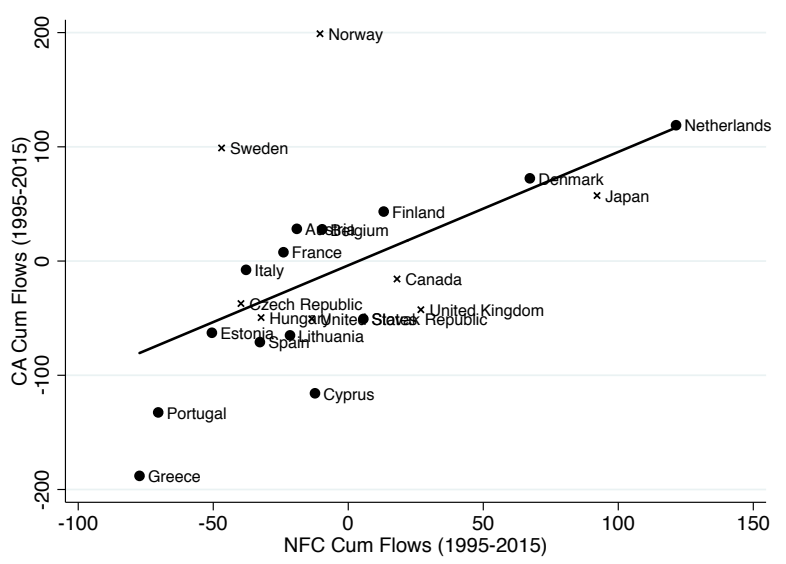

(c) NFC

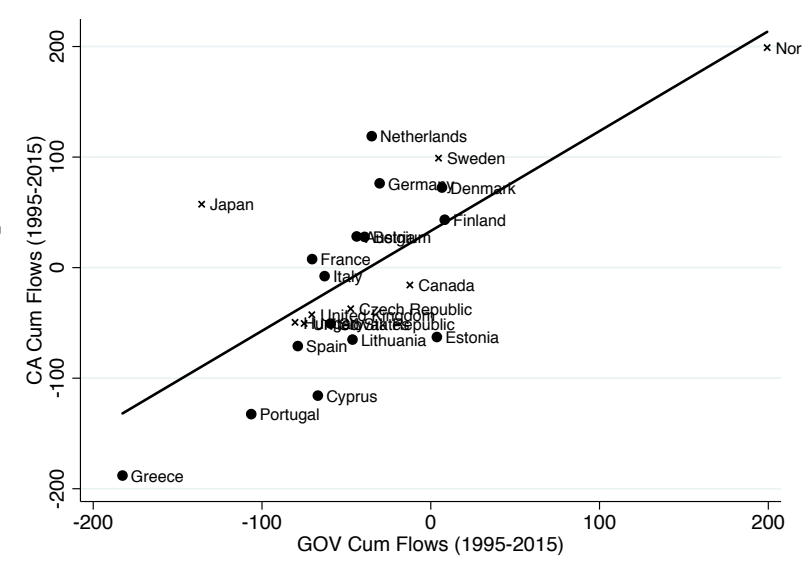

(b) GOV

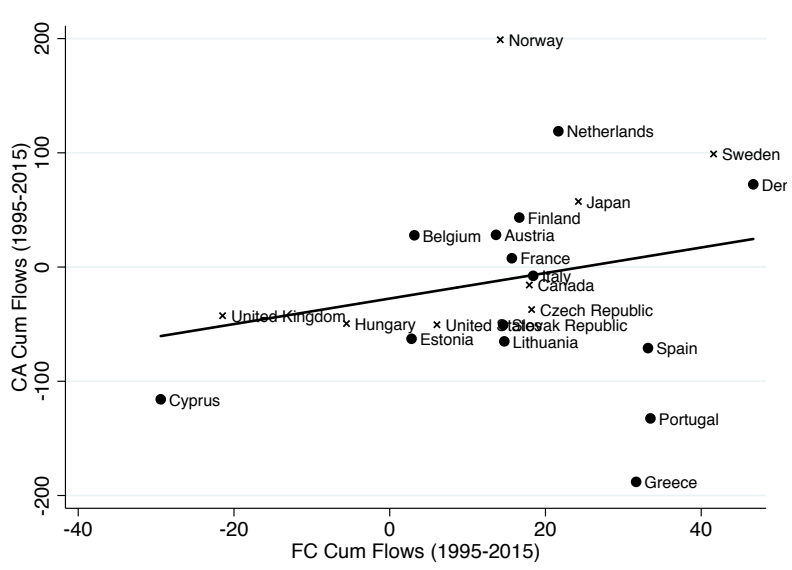

(d) FC

Note: HH: Households, NFC: Non-Financial Corporations, GOV: Government, FC: Financial Corporations. Cumulated net financial flows of each sector between 1995 and 2015 against the cumulated current account balance. In percent of 2015 GDP. Crosses represent economies with pegged exchange rate regimes and circles represent economies with non-pegged exchange rate regimes. 
Figure 4: Sectoral Contribution to Net International Investment Positions

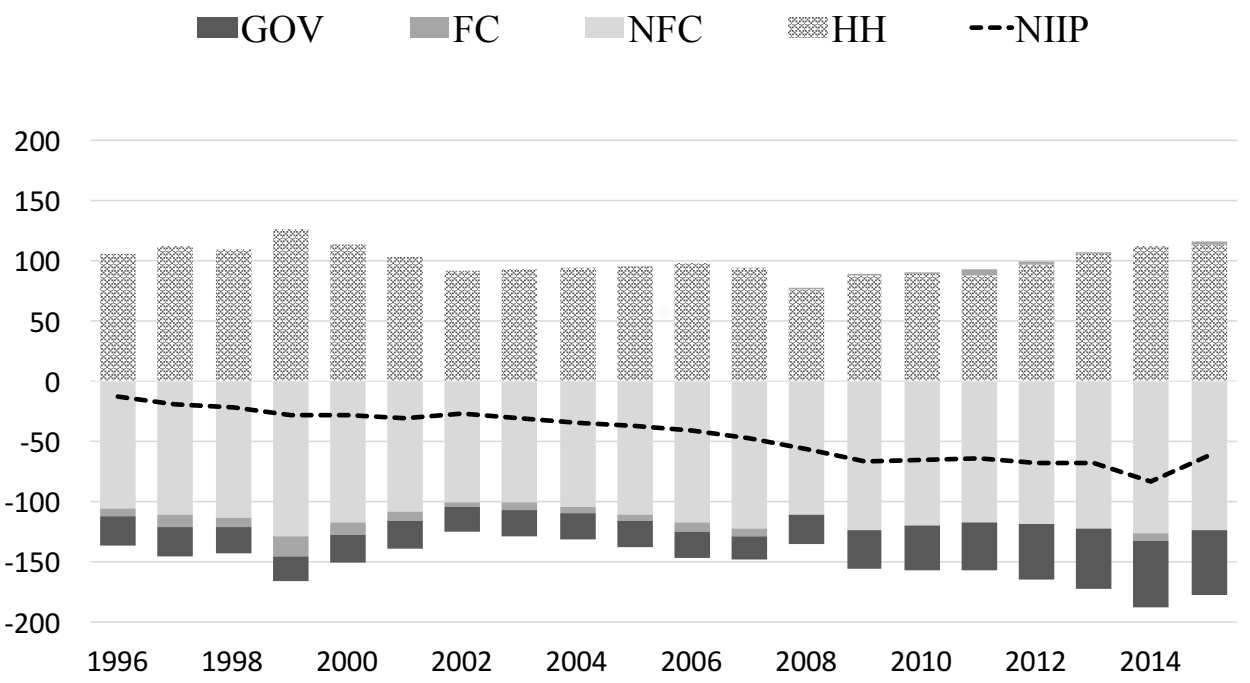

(a) Deficit Countries

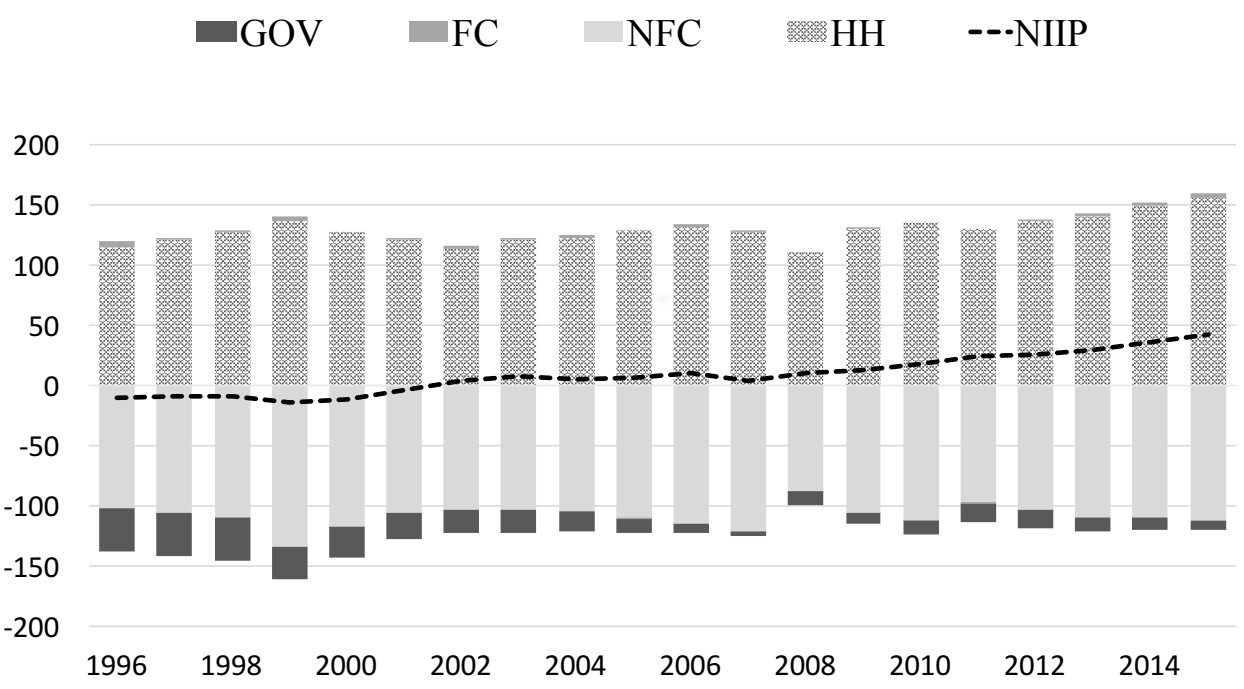

(b) Surplus Countries

Note: Average values of sectoral net financial positions and the net international investment position, weighted by country GDP. GOV: Government, FC: Financial Corporations, NFC: Non-Financial Corporations, HH: Households, NIIP: Net International Investment Position. Current account surplus countries are: France, Belgium, Sweden, the Netherlands, Canada, Denmark, Norway, Germany, Finland, Austria, and Japan. Current account deficit countries are: Portugal, Cyprus, the United Kingdom, Lithuania, Spain, Greece, Czech Republic, Hungary, the United States, Slovak Republic, Italy, and Estonia. 
Figure 5: Adjustment Process of the Current Account and Previous Imbalances

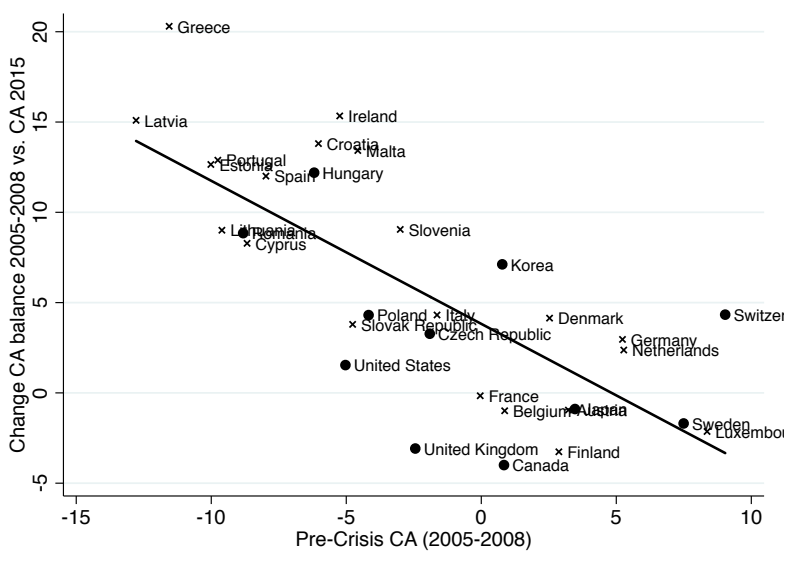

(a) $\mathrm{CA}$

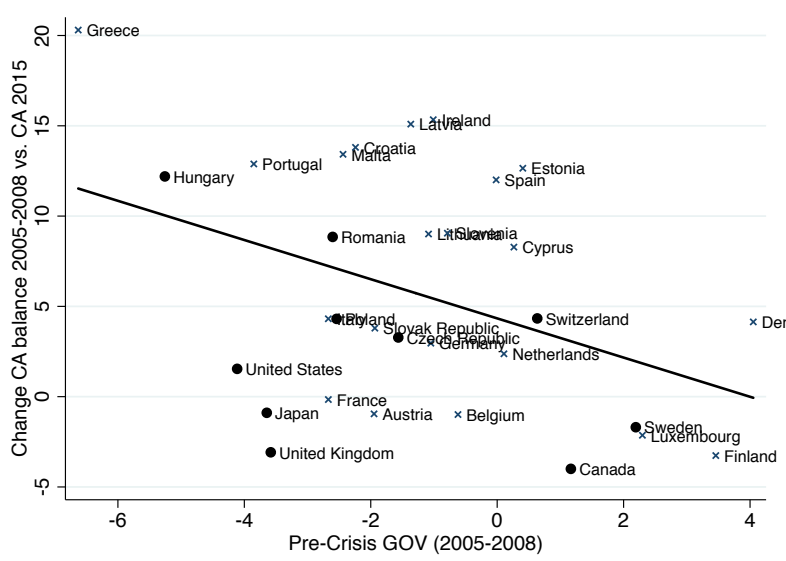

(c) GOV

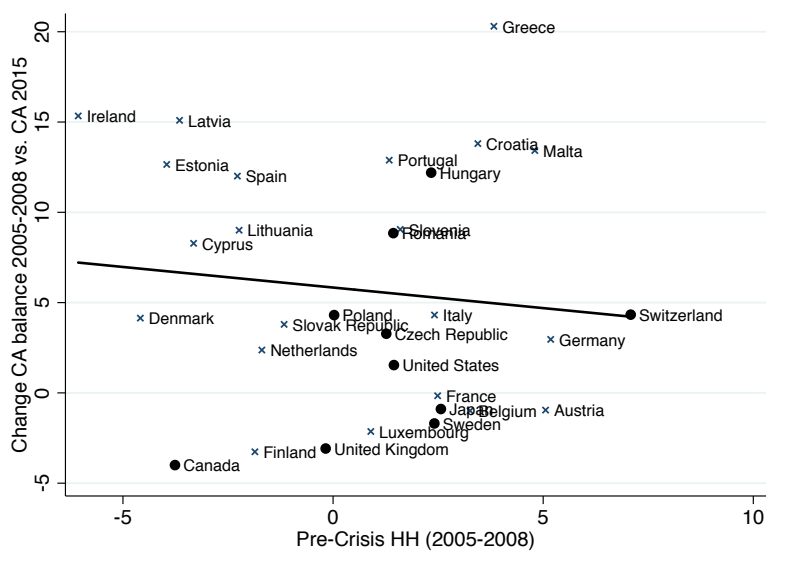

(b) $\mathrm{HH}$

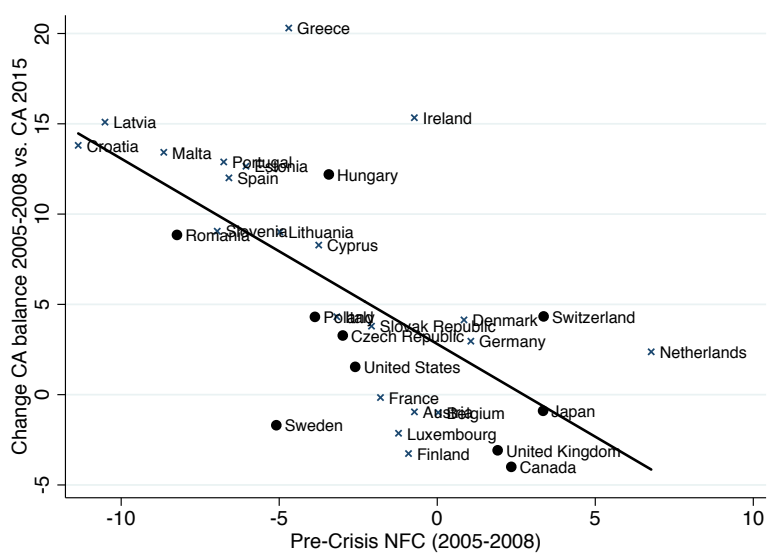

(d) NFC

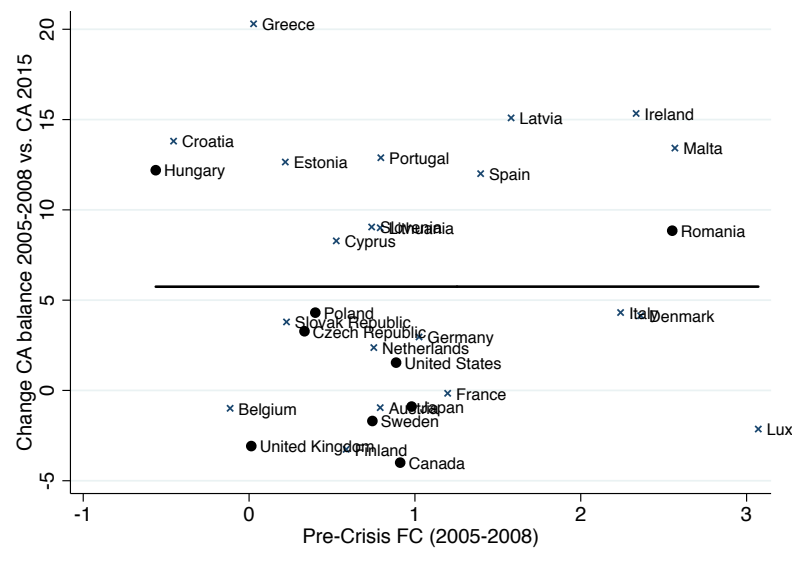

(e) FC

Note: CA: Current Account, HH: Households, NFC: Non-Financial Corporations, GOV: Government, FC: Financial Corporations. Relationship between the adjustment of the current account since 2008 (i.e. the change between the average current account balance between 2005-2008 average and its 2015 value) and the pre-crisis imbalance between 2005-2008 for the current account and each sectoral balance. In percent of 2015 GDP. Crosses represent economies with pegged exchange rate regimes and circles represent economies with non-pegged exchange rate regimes. 
Figure 6: Average Adjustment Conditional on Pre-Crisis Current Account Gap

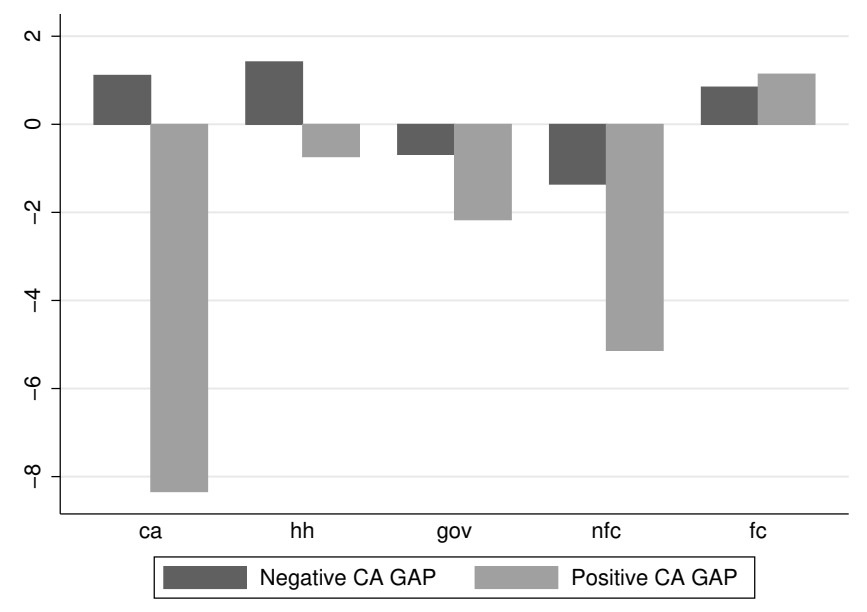

(a) Pre-Crisis Flows

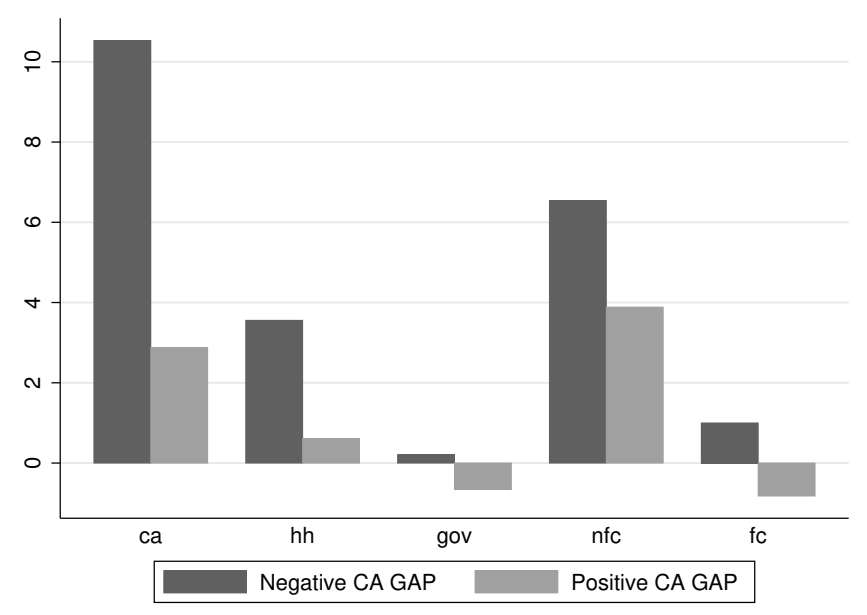

(b) Post-Crisis Flows

Note: Figure (a) shows the average pre-crisis imbalance between 20052008 for the current account and each sectoral balance in percent of 2015 GDP. The countries are split into negative and positive pre-crisis current account gap. Figure (b) shows the average adjustment of the current account since 2008 (i.e. the change between the average current account balance between 2005-2008 and its 2015 value) in percent of 2015 GDP. The negative gap countries are: Bulgaria, Latvia, Greece, Ireland, Serbia, the United States, Lithuania, Romania, Portugal, Estonia, Spain, Malta, Cyprus, and the United Kingdom. The positive gap countries are: Slovak Republic, Luxembourg, Croatia, Slovenia, Hungary, Italy, Belgium, France, Poland, Denmark, Czech Republic, Canada, Finland, Austria, Korea, Rep., the Netherlands, Switzerland, Germany, Japan, Norway, and Sweden. 
Figure 7: Large and Persistent Current Account Episodes: Cumulated Changes in Flows

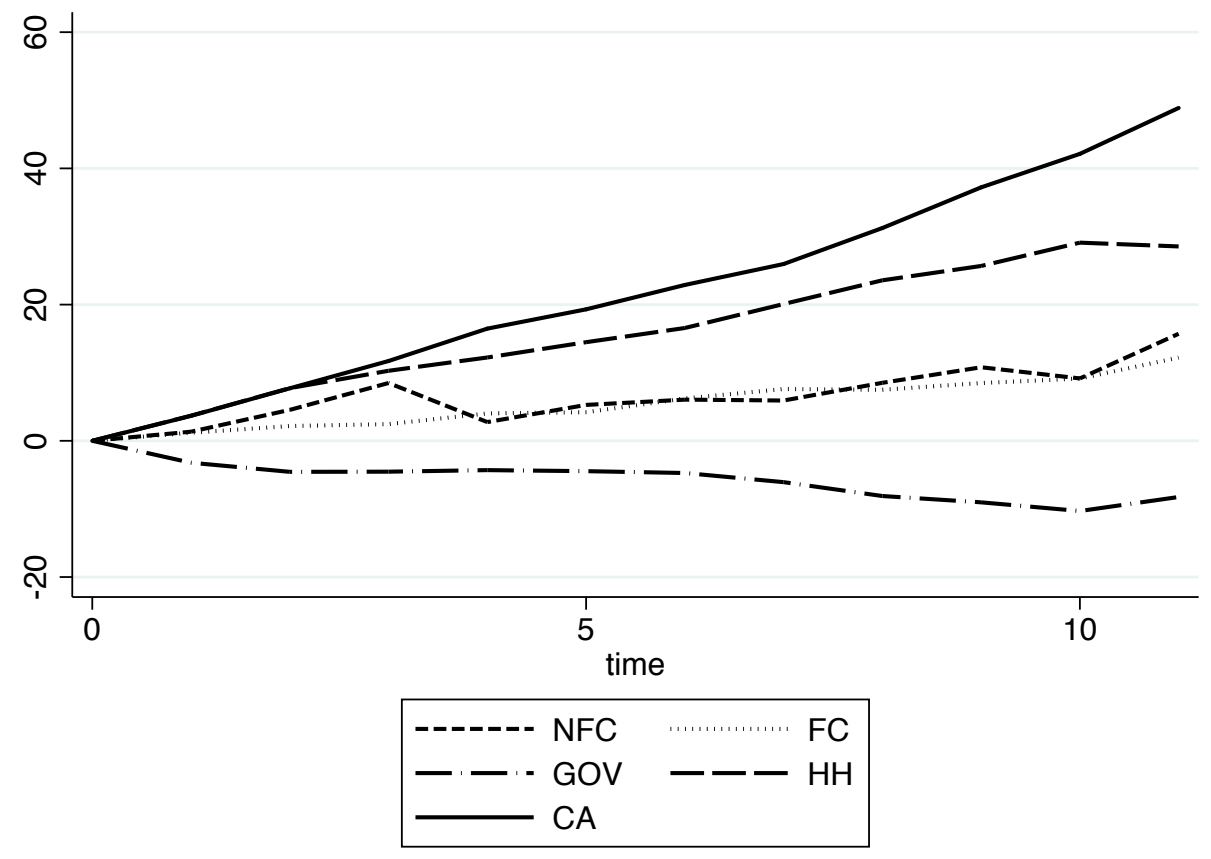

(a) Current Account Surplus

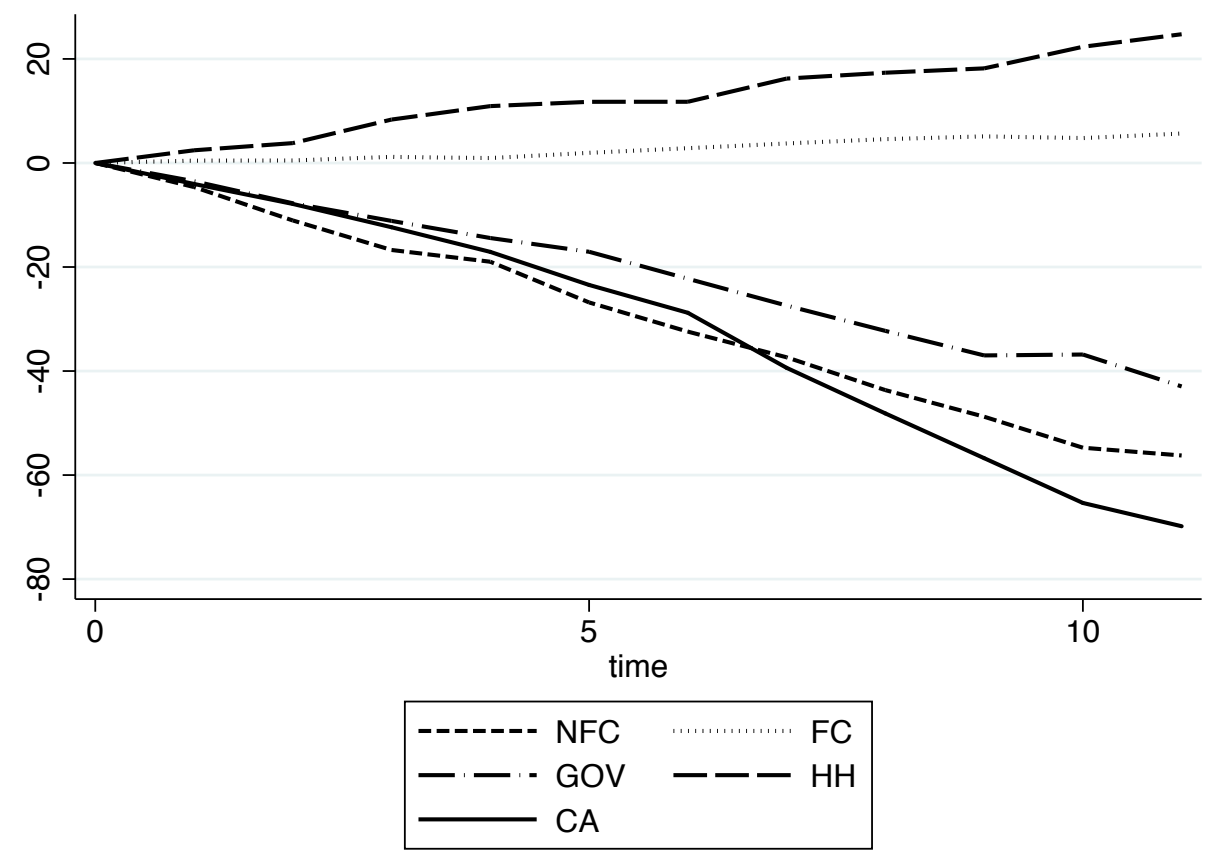

(b) Current Account Deficit

Note: This figure plots the cumulated changes of the sectoral and current account balance during episodes of large and persistent imbalances. In percent of GDP. CA: Current Account, HH: Households, NFC: Non-Financial Corporations, GOV: Government, FC: Financial Corporations. Large surplus and deficit episodes correspond to periods of imbalances larger or equal to 3 percent of GDP for at least 5 consecutive years. 
Figure 8: Large and Persistent Current Account Episodes: Changes in Wealth

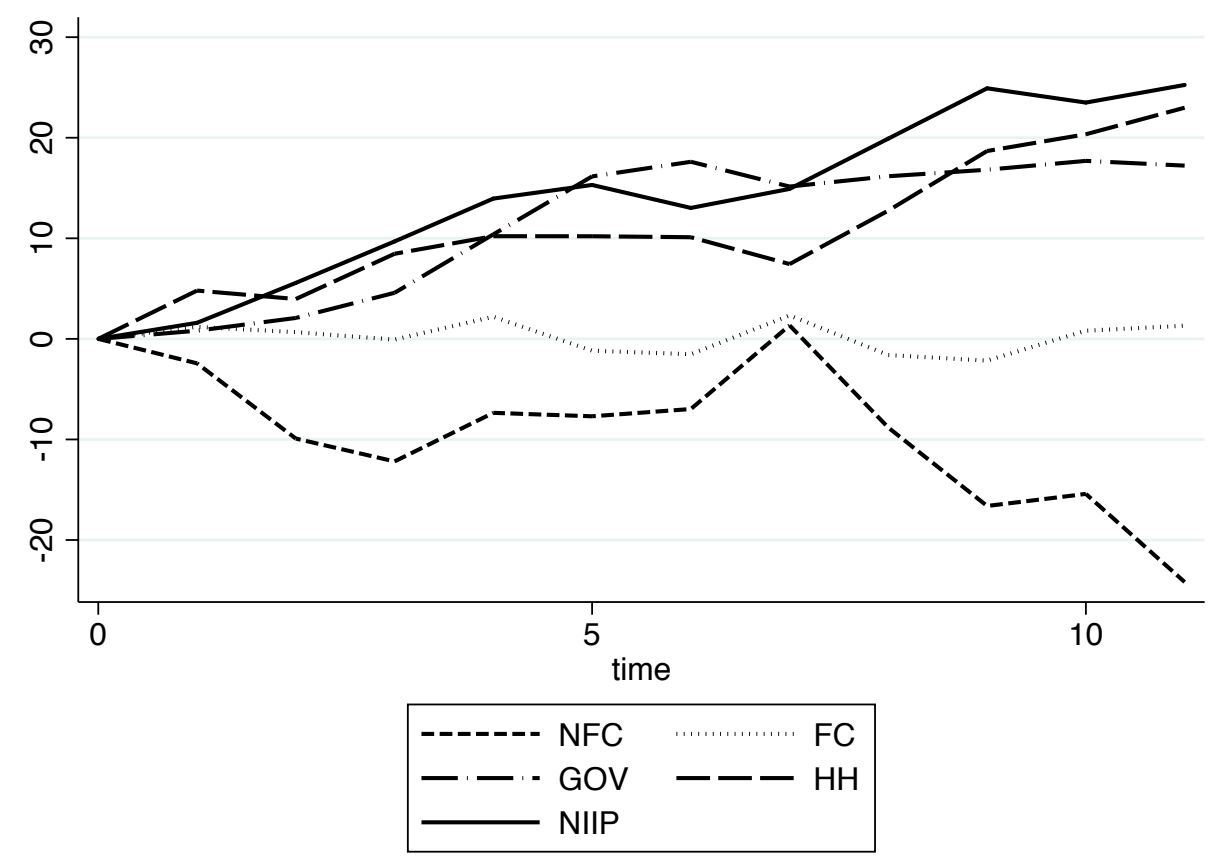

(a) Current Account Surplus

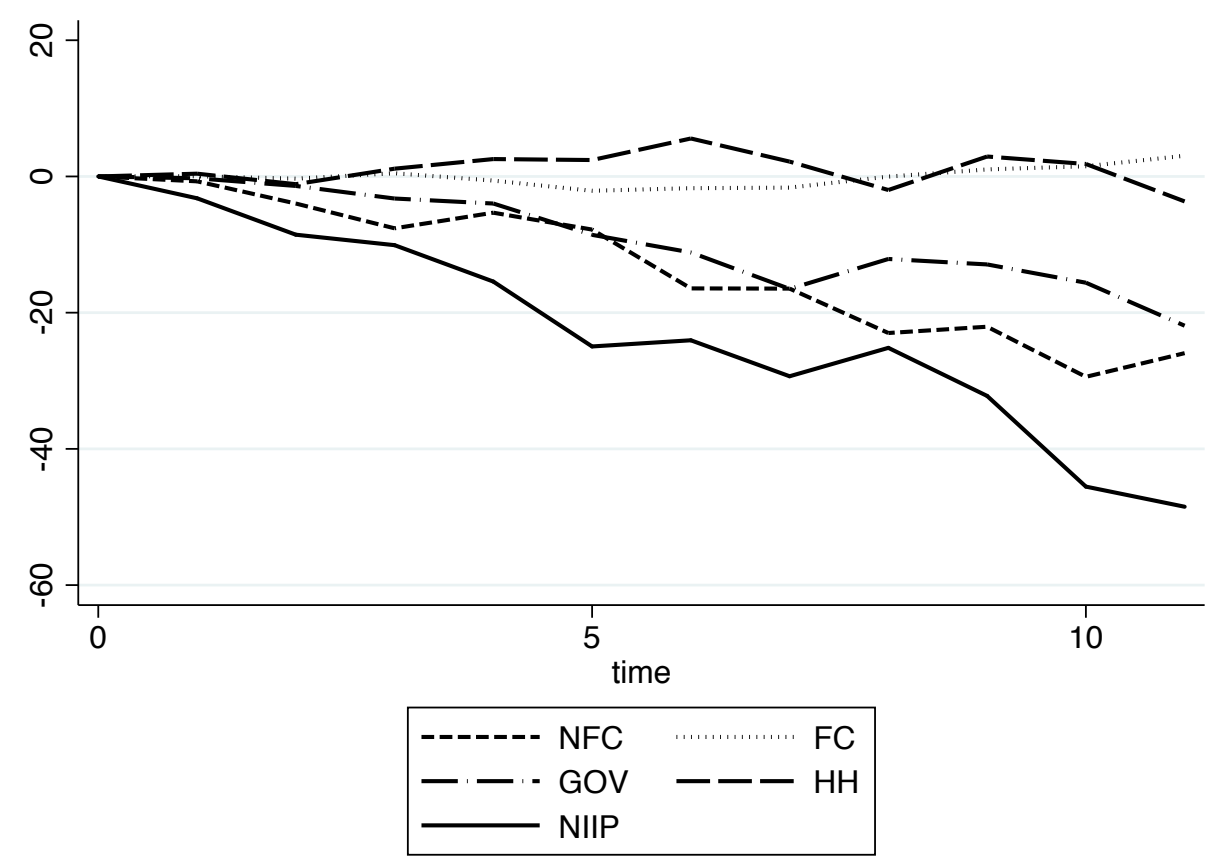

(b) Current Account Deficit

Note: This figure plots the cumulated changes of the sectoral and external position during episodes of large and persistent current account imbalances. In percent of GDP. NIIP: Net International Investment Position, HH: Households, NFC: Non-Financial Corporations, GOV: Government, FC: Financial Corporations. Large surplus and deficit episodes correspond to periods of imbalances larger or equal to 3 percent of GDP for at least 5 consecutive years. 
Table 1: Net Sectoral Financial Positions

\begin{tabular}{lccccc}
\hline \hline & & & & \\
& & & & \\
& & \multicolumn{5}{c}{$\mathbf{2 0 0 2}$} \\
& & & & & \\
\cline { 2 - 6 } All & -8.3 & 178.1 & -51.3 & -113.8 & -8.6 \\
Surplus & 11.6 & 149.2 & -50.6 & -89.1 & -0.2 \\
Deficit & -21.9 & 197.9 & -51.8 & -130.8 & -14.3 \\
& & & & & \\
& & & $\mathbf{2 0 0 7}$ & & \\
\cline { 2 - 6 } All & -5.5 & 196.2 & -48.6 & -137.5 & -5.0 \\
Surplus & 14.7 & 157.6 & -41.9 & -104.5 & 0.8 \\
Deficit & -19.7 & 223.2 & -53.3 & -160.4 & -9.0 \\
& & & & & \\
& & & $\mathbf{2 0 1 5}$ & & \\
\cline { 2 - 6 } All & -12.6 & 242.1 & -80.7 & -148.8 & -1.3 \\
Surplus & 55.7 & 154.5 & -35.9 & -95.8 & 8.2 \\
Deficit & -40.7 & 278.3 & -99.1 & -170.7 & -5.2 \\
\hline \hline
\end{tabular}

Note: Average sectoral net positions for the whole sample, the current account surplus countries sub-sample and the current account deficit countries sub-sample. Net positions are calculated as total financial assets minus financial liabilities in percent of GDP. HH: Households, NFC: Non-Financial Corporations, FC: Financial Corporations, GOV: Government, NIIP: Net International Investment Position. 
Table 2: The Covariates of the Current Account Balance

\begin{tabular}{lccccc}
\hline \hline & $(1)$ & $(2)$ & $(3)$ & $(4)$ & $(5)$ \\
& $\mathrm{CA}$ & $\mathrm{HH}$ & $\mathrm{GOV}$ & $\mathrm{NFC}$ & $\mathrm{FC}$ \\
\hline GDP Growth & $-0.177^{* *}$ & -0.033 & $0.169^{* *}$ & $-0.260^{* * *}$ & -0.056 \\
& $(0.080)$ & $(0.066)$ & $(0.069)$ & $(0.063)$ & $(0.042)$ \\
Population growth & $-2.364^{* * *}$ & 0.076 & $-1.351^{* * *}$ & -0.482 & $-0.918^{* * *}$ \\
& $(0.630)$ & $(0.477)$ & $(0.454)$ & $(0.570)$ & $(0.318)$ \\
GDP per capita & $0.254^{* * *}$ & $-0.057^{* * *}$ & $0.223^{* * *}$ & 0.044 & $0.028^{*}$ \\
& $(0.033)$ & $(0.020)$ & $(0.031)$ & $(0.026)$ & $(0.016)$ \\
Dependency ratio (old) & -0.102 & $0.182^{* * *}$ & $-0.122^{* *}$ & $-0.187^{* * *}$ & -0.026 \\
& $(0.068)$ & $(0.047)$ & $(0.061)$ & $(0.065)$ & $(0.047)$ \\
Aging Speed & 0.008 & -0.038 & $-0.225^{* * *}$ & $0.183^{* * *}$ & 0.049 \\
& $(0.064)$ & $(0.041)$ & $(0.056)$ & $(0.058)$ & $(0.035)$ \\
Lagged NIIP & 0.011 & $0.014^{* *}$ & -0.006 & 0.007 & -0.004 \\
& $(0.011)$ & $(0.006)$ & $(0.008)$ & $(0.009)$ & $(0.008)$ \\
Global Financial Crisis & $-0.056^{* * *}$ & $-0.026^{* *}$ & -0.001 & -0.019 & -0.005 \\
& $(0.012)$ & $(0.010)$ & $(0.009)$ & $(0.012)$ & $(0.007)$ \\
Financial Center & $0.015^{*}$ & $0.012^{* * *}$ & $-0.013^{* *}$ & $0.018^{* * *}$ & -0.002 \\
& $(0.008)$ & $(0.004)$ & $(0.005)$ & $(0.007)$ & $(0.005)$ \\
\hline Observations & 156 & 156 & 156 & 156 & 156 \\
Adjusted $R^{2}$ & 0.57 & 0.25 & 0.49 & 0.37 & 0.05 \\
\hline \hline
\end{tabular}

Panel OLS estimation over the 1995-2015 period with 3 year non-overlapping averages and robust standards errors. Time fixed effects are included. The dependent variables are the current account balance (CA) and the net financial balances of the main domestic sectors (HH: Households, GOV: Government, NFC: Non-Financial Corporations, FC: Financial Corporations), in percent of GDP. See text for more information of the control variables. ${ }^{*} p<0.10,{ }^{* *} p<0.05,{ }^{* * *} p<0.01$ 
Table 3: Adjustment Process of the Current Account and Previous Imbalances

\begin{tabular}{|c|c|c|c|c|c|c|c|}
\hline & $\begin{array}{c}(1) \\
\Delta C A_{0508-15}\end{array}$ & $\begin{array}{c}(2) \\
\Delta C A_{0508-15}\end{array}$ & $\begin{array}{c}(3) \\
\Delta C A_{0508-15}\end{array}$ & $\begin{array}{c}(4) \\
\Delta C A_{0508-15}\end{array}$ & $\begin{array}{c}(5) \\
\Delta C A_{0508-15}\end{array}$ & $\begin{array}{c}(6) \\
\Delta C A_{0508-15}\end{array}$ & $\begin{array}{c}(7) \\
\Delta C A_{0508-15}\end{array}$ \\
\hline$C A_{0508}$ & $\begin{array}{c}-0.862^{* * *} \\
(0.140)\end{array}$ & & & & & & \\
\hline$G A P_{0508}$ & & & $\begin{array}{c}-0.284^{* * *} \\
(0.067)\end{array}$ & $\begin{array}{c}-0.316^{* * *} \\
(0.075)\end{array}$ & $\begin{array}{c}-0.268^{* * *} \\
(0.064)\end{array}$ & $\begin{array}{c}-0.218^{* *} \\
(0.082)\end{array}$ & $\begin{array}{c}-0.251^{* * *} \\
(0.076)\end{array}$ \\
\hline$H H_{0508}$ & & $\begin{array}{l}-0.720^{*} \\
(0.356)\end{array}$ & & $\begin{array}{c}0.436 \\
(0.291)\end{array}$ & & & \\
\hline$G O V_{0508}$ & & $\begin{array}{c}-1.199^{* *} \\
(0.455)\end{array}$ & & & $\begin{array}{l}-0.356 \\
(0.400)\end{array}$ & & \\
\hline$N F C_{0508}$ & & $\begin{array}{c}-0.842^{* * *} \\
(0.259)\end{array}$ & & & & $\begin{array}{c}-0.581^{* *} \\
(0.265)\end{array}$ & \\
\hline$F C_{0508}$ & & $\begin{array}{c}1.014 \\
(0.878)\end{array}$ & & & & & $\begin{array}{c}0.514 \\
(1.137)\end{array}$ \\
\hline$N I I P_{0407}$ & $\begin{array}{c}0.009 \\
(0.037)\end{array}$ & $\begin{array}{l}-0.046 \\
(0.038)\end{array}$ & $\begin{array}{l}-0.036 \\
(0.037)\end{array}$ & $\begin{array}{l}-0.043 \\
(0.032)\end{array}$ & $\begin{array}{l}-0.030 \\
(0.038)\end{array}$ & $\begin{array}{l}-0.011 \\
(0.037)\end{array}$ & $\begin{array}{c}-0.088^{* *} \\
(0.039)\end{array}$ \\
\hline Observations & 31 & 30 & 31 & 31 & 31 & 31 & 30 \\
\hline Adjusted $R^{2}$ & 0.55 & 0.60 & 0.47 & 0.49 & 0.46 & 0.54 & 0.53 \\
\hline
\end{tabular}

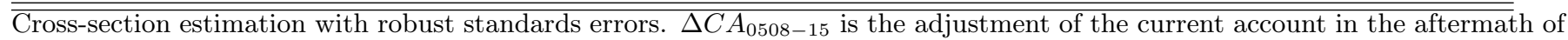
the crisis (i.e. the change between the average current account balance between 2005-2008 and its 2015 value). GAP is the precrisis current account gap. HH: Households, GOV: Government, NFC: Non-Financial Corporations, FC: Financial Corporations. Sector balances are average flows between 2005-2008. We drop the following most extreme cases: Iceland, Norway and Bulgaria. ${ }^{*} p<0.10,{ }^{* *} p<0.05,{ }^{* * *} p<0.01$ 
Table 4: Sectoral Adjustments and Pre-Crisis Current Account Gap

\begin{tabular}{lccccc}
\hline \hline \multirow{5}{*}{} & $(1)$ & $(2)$ & $(3)$ & $(4)$ & $(5)$ \\
& $\Delta C A_{0508-15}$ & $\Delta H H_{0508-15}$ & $\Delta G O V_{0508-15}$ & $\Delta N F C_{0508-15}$ & $\Delta F C_{0508-15}$ \\
\hline AAP $_{0508}$ & $-0.284^{* * *}$ & -0.102 & -0.028 & $-0.107^{* *}$ & -0.019 \\
& $(0.067)$ & $(0.062)$ & $(0.037)$ & $(0.049)$ & $(0.096)$ \\
NIIP $P_{0407}$ & -0.036 & 0.004 & -0.012 & $-0.058^{* *}$ & -0.015 \\
& $(0.037)$ & $(0.021)$ & $(0.016)$ & $(0.026)$ & $(0.065)$ \\
\hline Observations & 31 & 31 & 31 & 31 & 30 \\
Adjusted $R^{2}$ & 0.47 & 0.07 & 0.00 & 0.31 & 0.00 \\
\hline \hline
\end{tabular}

Cross-sectional regression with robust standards errors. The dependent variable are the post-crisis adjustment of the Current Account (CA), and the net financial balances of the domestic sectors (i.e. the change between the average balance between 2005-2008 and its 2015 value). Households (HH), Government (GOV), Non-Financial Corporations (NFC), Financial Corporations (FC). GAP is the pre-crisis current account gap. We drop the following most extreme cases: Iceland, Norway and Bulgaria. ${ }^{*} p<0.10,{ }^{* *} p<0.05,{ }^{* * *} p<0.01$ 
Table 5: Average Net Sectoral Balance During Current Account Imbalances

\begin{tabular}{lrrrrr}
\hline \hline & CA & HH & GOV & NFC & \multicolumn{1}{c}{ FC } \\
\hline Surplus & 7.0 & 3.2 & 0.6 & 0.5 & 1.3 \\
Deficit & -7.0 & 2.0 & -3.8 & -4.9 & -4.8 \\
No Episode & -0.2 & 3.0 & -3.2 & -0.2 & 0.8 \\
\hline
\end{tabular}

Note: Average net sectoral balance during current account episodes. In percent of GDP. Surplus corresponds to periods where the current account is in surplus of 3 percent or more of GDP. Deficit periods correspond to periods of deficits larger or equal to -3 percent of GDP. No Episode signifies the current account does not fall into the two categories above. 
Table 6: Persistent Current Account Deficits Episodes

\begin{tabular}{lcccccccccc}
\hline \hline & & & & \multicolumn{3}{c}{ Private } & \multicolumn{3}{c}{ Public } & Foreign \\
\cline { 8 - 9 } & Start & End & N & HH & NFC & FC & Total & GOV & CA & Type \\
\hline United States & 1998 & 2015 & 18 & 52.9 & -17.2 & 7.6 & 43.3 & -95.4 & -63.8 & $\mathrm{G}$ \\
United Kingdom & 2006 & 2015 & 10 & 14.9 & 22.5 & -5.1 & 32.4 & -59.0 & -33.2 & $\mathrm{G}$ \\
Canada & 2009 & 2015 & 7 & -19.4 & 2.2 & 8.9 & -8.3 & -17.7 & -22.4 & $\mathrm{G}$ \\
Greece & 1995 & 2012 & 18 & 36.6 & -41.0 & 4.2 & -0.2 & -93.1 & -104.8 & $\mathrm{G}$ \\
Ireland & 2005 & 2009 & 5 & -21.3 & -4.9 & 19.1 & -7.1 & -16.6 & -25.2 & $\mathrm{G}$ \\
Portugal & 1996 & 2011 & 16 & 24.1 & -60.2 & 14.6 & -21.5 & -64.1 & -104.2 & $\mathrm{G}$ \\
Spain & 1999 & 2011 & 13 & -0.1 & -31.5 & 12.6 & -19.1 & -30.1 & -55.3 & $\mathrm{G}$ \\
Cyprus & 2000 & 2015 & 16 & 3.1 & -9.6 & -21.0 & -27.5 & -42.7 & -81.2 & $\mathrm{G}$ \\
Czech Republic & 1995 & 2011 & 17 & 73.3 & -105.3 & 41.4 & 9.4 & -118.7 & -101.1 & $\mathrm{G}$ \\
Slovak Republic & 1996 & 2011 & 16 & -7.4 & -47.5 & 31.4 & -23.5 & -181.9 & -212.0 & $\mathrm{G}$ \\
Hungary & 1995 & 2008 & 14 & 98.8 & -117.3 & -7.5 & -26.0 & -147.0 & -161.2 & $\mathrm{G}$ \\
Poland & 2004 & 2012 & 9 & 13.2 & -20.7 & 8.4 & 0.8 & -34.3 & -37.0 & $\mathrm{G}$ \\
Romania & 1998 & 2012 & 15 & 40.0 & -61.8 & 6.2 & -15.6 & -39.2 & -65.1 & $\mathrm{G}$ \\
Croatia & 2002 & 2009 & 8 & 19.6 & -59.9 & -2.2 & -42.6 & -23.4 & -37.3 & $\mathrm{P}$ \\
Lithuania & 1995 & 2008 & 14 & -1.2 & -35.2 & 5.4 & -31.0 & -13.5 & -60.0 & $\mathrm{P}$ \\
Latvia & 2004 & 2008 & 5 & -26.0 & -66.3 & 9.5 & -82.8 & -9.0 & -84.0 & $\mathrm{P}$ \\
Estonia & 1995 & 2008 & 14 & -27.2 & -63.0 & 4.4 & -85.8 & 4.5 & -86.1 & $\mathrm{P}$ \\
Bulgaria & 2001 & 2009 & 9 & 45.3 & -119.9 & -13.8 & -88.4 & -0.2 & -72.4 & $\mathrm{P}$ \\
\hline Mean & & & & 21.9 & -45.3 & 4.9 & -18.5 & -53.0 & -76.3 & \\
\hline \hline
\end{tabular}

Note: The sample covers the 1995-2015 period. Deficit periods correspond to periods of deficits larger or equal to -3 percent of GDP. Type G is when the Net Financial Balance of the Government sector is larger than the balance of the private sector (households, non-financial and financial corporations), Type $\mathrm{P}$ is when the private sector balance is larger than the public sector. There are 5 P-type episodes and 14 G-type episodes. We drop Malta (2004-2011) due to the difference between the sum of domestic balances and external balances. 
Table 7: Persistent Current Account Surplus Episodes

\begin{tabular}{lcccccccccc}
\hline & & & & \multicolumn{3}{c}{ Private } & \multicolumn{3}{c}{ Public } & Foreign \\
\cline { 8 - 10 } & Start & End & $\mathrm{N}$ & HH & NFC & FC & Total & GOV & CA & Type \\
\hline Austria & 2005 & 2010 & 6 & 29.0 & 1.3 & 4.4 & 34.7 & -17.7 & 18.2 & $\mathrm{P}$ \\
Belgium & 1995 & 2005 & 11 & 99.8 & -8.8 & -3.5 & 87.4 & -20.3 & 55.1 & $\mathrm{P}$ \\
Denmark & 2001 & 2015 & 15 & -24.5 & 48.5 & 39.6 & 63.6 & 7.0 & 62.5 & $\mathrm{P}$ \\
France & 1997 & 2001 & 5 & 21.0 & -0.9 & 2.8 & 22.9 & -11.5 & 17.5 & $\mathrm{P}$ \\
Germany & 2004 & 2015 & 12 & 66.6 & 18.2 & 6.1 & 90.9 & -15.7 & 77.5 & $\mathrm{P}$ \\
Japan & 1999 & 2011 & 13 & 41.6 & 65.5 & 23.6 & 130.6 & -89.0 & 43.3 & $\mathrm{P}$ \\
Korea & 2009 & 2015 & 7 & 35.7 & -19.9 & 8.3 & 24.1 & 5.7 & 29.3 & $\mathrm{P}$ \\
Netherlands & 1995 & 2015 & 21 & 15.0 & 109.6 & 19.9 & 144.6 & -35.0 & 105.9 & $\mathrm{P}$ \\
Sweden & 1995 & 2015 & 21 & 58.5 & -43.3 & 42.7 & 57.8 & 0.2 & 100.0 & $\mathrm{P}$ \\
Finland & 1995 & 2008 & 14 & -7.7 & 31.5 & 15.1 & 38.9 & 43.3 & 88.4 & $\mathrm{G}$ \\
Norway & 1996 & 2015 & 20 & -8.1 & -13.5 & 18.4 & -3.3 & 258.0 & 257.6 & $\mathrm{G}$ \\
\hline Mean & & & & 31.0 & 4.9 & 20.7 & 56.6 & 12.1 & 83.2 & \\
\hline \hline
\end{tabular}

Note: The sample covers the 1995-2015 period. Surplus periods correspond to periods of surplus larger or equal to -3 percent of GDP. Type G is when the Net Financial Balance of the Government sector is larger than the balance of the private sector (households, non-financial and financial corporations), Type $\mathrm{P}$ is when the private sector balance is larger than the public sector. We drop Luxembourg (2002-2015) due to the difference between the sum of domestic balances and external balances. 


\section{Appendix A Data Definitions and Sources}

Table D1: Data Definitions and Sources

\begin{tabular}{lll}
\hline \hline Variable & Source & Description \\
\hline Net financial balance & Eurostat \& OECD financial accounts (non consolidated) & ratio to GDP \\
Net financial position & Eurostat \& OECD financial balance sheets (non consolidated) & ratio to GDP \\
Sectoral Saving & Eurostat \& OECD non-financial accounts & ratio to GDP \\
Sectoral Investment & Eurostat \& OECD non-financial accounts & ratio to GDP \\
Current Account & IMF IFS & as a ratio to GDP \\
GDP growth & IMF IFS & in percent \\
Population growth & United Nations & in percent \\
Dependency ratio (old) & United Nations & ratio of people older \\
& & than 64 to ages 15-64 \\
Dependency ratio (young) & United Nations & ratio of people younger \\
& & than 14 to ages 15-64 \\
Aging & United Nations & diffence between expected \\
& & old age dependency \\
ratio in (t+20) and (t) \\
Terms of Trade & redio between the index of \\
NIIP & External Wealth of Nations & export and import prices \\
Private credit & World Bank & as a ratio to GDP \\
GDP per capita & United Nations \& IMF IFS & as a ratio to GDP \\
EBA-lite & IMF & in levels \\
see EBA lite (2016)
\end{tabular}

\section{Appendix B Country Coverage}

Full sample: the United States, the United Kingdom, Austria, Belgium, Denmark, France, Germany, Italy, Luxembourg, the Netherlands, Norway, Sweden, Switzerland, Canada, Japan, Finland, Greece, Iceland, Ireland, Malta, Portugal, Spain, Cyprus, Korea, Bulgaria, Czech Republic, Slovak Republic, Estonia, Latvia, Hungary, Lithuania, Croatia, Slovenia, Poland, Romania.

Reduced sample: Surplus countries: France, Belgium, Sweden, the Netherlands, Canada, Denmark, Norway, Germany, Finland, Austria, Japan. Deficit countries: Portugal, Cyprus, the United Kingdom, Lithuania, Spain, Greece, Czech Republic, Hungary, the United States, Slovak Republic, Italy, Estonia.

Current account gap sub-samples: Positive gap: Slovak Republic, Luxembourg, Croatia, Slovenia, Hungary, Italy, Belgium, France, Poland, Denmark, Czech Republic, Canada, Finland, Austria, Rep. of Korea, the Netherlands, Switzerland, Germany, Japan, Norway, Sweden. Negative gap: Bulgaria, Latvia, Greece, Ireland, Serbia, the United States, Lithuania, Romania, Portugal, Estonia, Spain, Malta, Cyprus, the United Kingdom. 


\section{Appendix C The Consistency between the Rest of the World Ac- count and the Balance of Payments Statistics}

The new methodology of the balance of payments statistics (BOP) and the rest of the world account (ROW) in the sectoral national accounts (BPM6 Appendix 7 and ESA 2010 Chapter 18) requires full consistency between the two statistics. However, some statistical discrepancies remain. For instance, discrepancies between the net lending of the quarterly Financial Accounts of the BOP and ROW account in the national accounts represented 2.2 percent of the European Union GDP in 2014, see Obrzut (2016). ${ }^{42}$

Recent Eurostat surveys in 2014 and 2015 (called the "BOP/ROW survey") showed different net recording practices (specifically for financial derivatives), differences in vintages and revisions and different compilation practices (for example some national statistics are compiled by national statistical offices while others are compiled by national central banks) were cited as the main explanations for the discrepancies.

The balance of payments is defined in BPM6 as summarizing transactions between residents and nonresidents during a period. It consists of the goods and services account, the primary income account, the secondary income account, the capital account, and the financial account. ${ }^{43}$ The stock counterpart is the International Investment Position (IIP) defined as a statistical statement that shows at a point in time the value of: financial assets of residents of an economy that are claims on nonresidents or are gold bullion held as reserve assets; and the liabilities of residents of an economy to nonresidents. ESA 2010 defines the rest of the world account as a grouping of units without any characteristic functions and resources; it consists of non-resident units insofar as they are engaged in transactions with resident institutional units, or have other economic links with resident units. Its accounts provide an overall view of the economic relationships linking the national economy with the rest of the world. These relationships can be transactions between resident and non-resident institutional units (like in the case of the current account in the balance of payments) and the related stocks of assets and liabilities (similarly in the international investment position).

However, although the two statistics have been made consistent in terms of methodological standards, there are elements that differentiate them. First, the perspective of the rest of the world is that of a non-resident sector that has a relationship with a counterparty sector in the domestic economy. The BOP/IIP is from the perspective of the resident sector. It follows that a current account (net international investment position) surplus of the resident economy is equivalent to a rest of the world financial balance (rest of the world financial position) deficit and vice versa. ${ }^{44}$ Additionally, the net lending/net borrowing in the BOP financial account compares to net acquisition

\footnotetext{
${ }^{42}$ Five member states that contribute most prominently to the total discrepancies are Germany, France, Denmark, Italy, and Greece. The discrepancies in terms of stock positions represented 4.4 percent of GDP.

${ }^{43}$ The balance of payments must add to zero, with the Current Account (CA), the Financial Account (FA), the Capital Account (KA) and net Errors and Omissions (EO) in the following manner:

$$
C A^{B O P}-\left(F A^{B O P}+K A^{B O P}\right)+E O^{B O P}=0
$$

${ }^{44}$ Assuming the capital account (KA) and the net errors and omissions (EO) are equal to zero.
} 
of assets/net incurrence of liabilities in the ROW account.

$$
N F B^{R O W}=-F A^{B O P}=-\left(C A^{B O P}+K A^{B O P}+E O^{B O P}\right)
$$

In terms of balance sheet positions, we have the following correspondence:

$$
N F P^{R O W}=-N I I P^{I I P}
$$

Second, in the rest of the world financial account, the primary classification is by the instrument of investment, whereas in the BOP/IIP financial account classification is given by functional category. A correspondence table maps the links between the functional categories to instrument categories in BPM6 Appendix 7, however, issues remain (Obrzut, 2016). For instance, some ESA 2010 financial instruments correspond to multiple BPM6 categories and other sector-specific instruments seem omitted. ${ }^{45}$

Even if the size of the discrepancy between the two statistics is relatively small, Figure D13 shows it can vary between countries, like the United Kingdom (with notoriously small discrepancies) and the United States (with larger discrepancies) for instance.

\section{Appendix D Additional Figures and Tables}

\footnotetext{
${ }^{45}$ F.5 "Equity" in ESA 2010 for example, could correspond to Direct Investment, Portfolio Investment and Other Investment in BPM6 depending on the nature of the equity.
} 
Figure D1: Unweighted Sectoral Contribution to Current Account Balances

GOV $\quad$ FC NFC

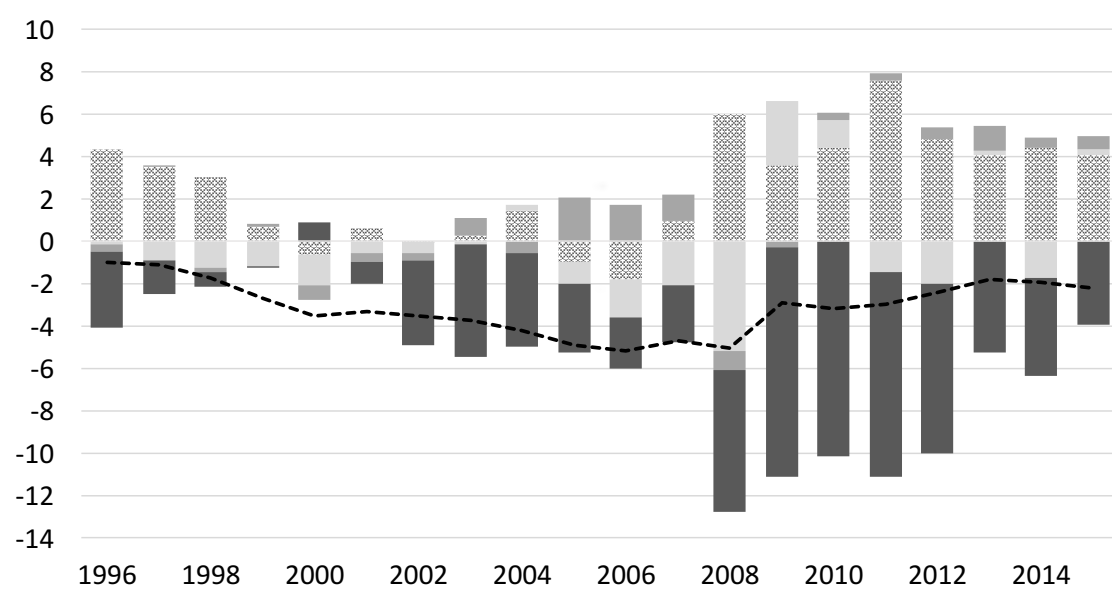

(a) Deficit Countries

$\begin{array}{lll}-\mathrm{GOV} & \mathrm{FC} & \mathrm{NFC}\end{array}$

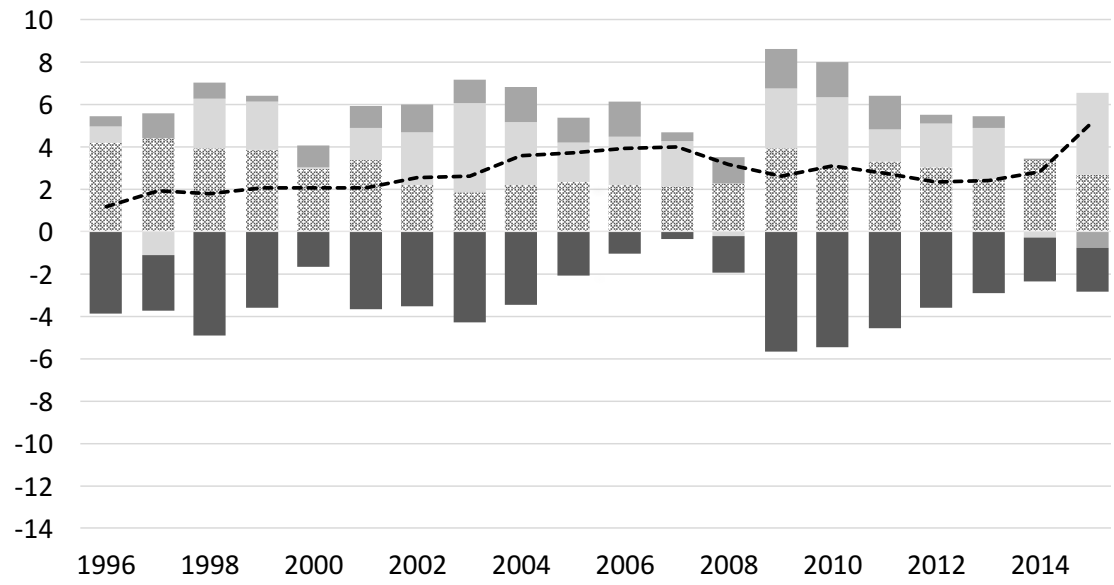

(b) Surplus Countries

Note: In percent of group GDP. GOV: Government, FC: Financial Corporations, NFC: Non-Financial Corporations, HH: Households, CA: Current Account. Current account surplus countries are: France, Belgium, Sweden, the Netherlands, Canada, Denmark, Norway, Germany, Finland, Austria, and Japan. Current account deficit countries are: Portugal, Cyprus, the United Kingdom, Lithuania, Spain, Greece, Czech Republic, Hungary, the United States, Slovak Republic, Italy, and Estonia. 
Figure D2: Corporate Sector Dynamics

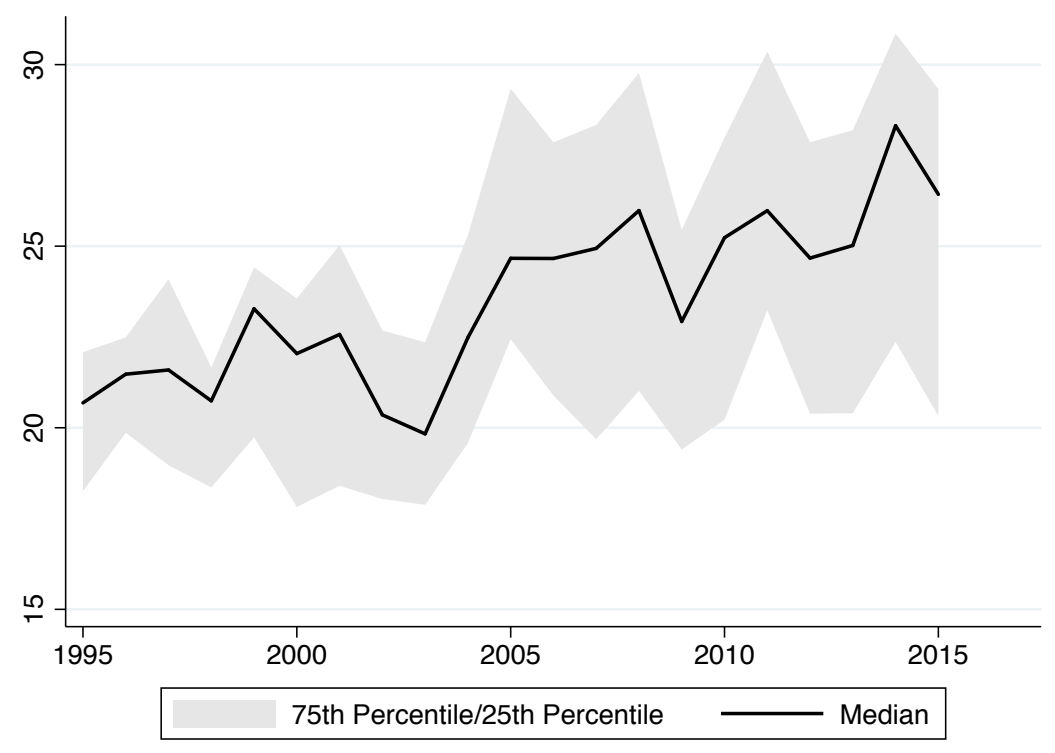

(a) Earnings of the NFC sector

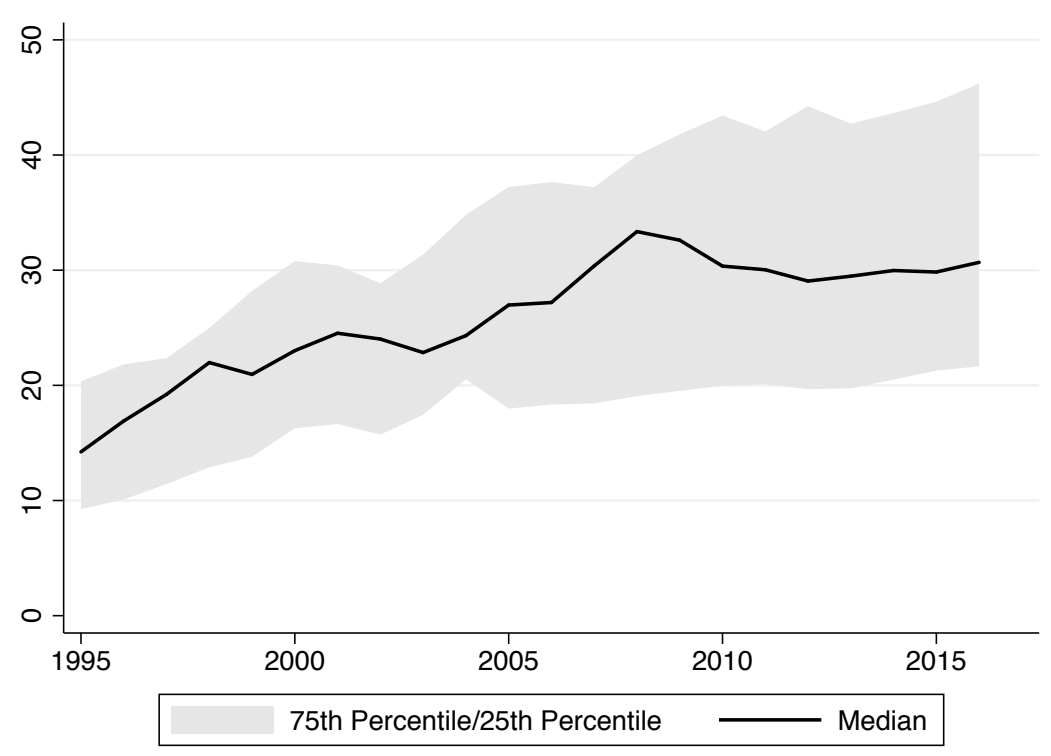

(b) Foreign Ownership of the NFC and FC sectors

Note: Figure (a) shows the Gross Operating Surplus of the NFC sector in percent of GDP. Figure (b) depicts the share of the equity holdings of foreign portfolio and foreign direct investors relative to domestic outstanding equities of the NFC and FC sector. Error bands represent the 25th and 75th percentiles. 
Figure D3: Unweighted Sectoral Contribution to Net International Investment Positions

GOV $\quad$ FC NFC

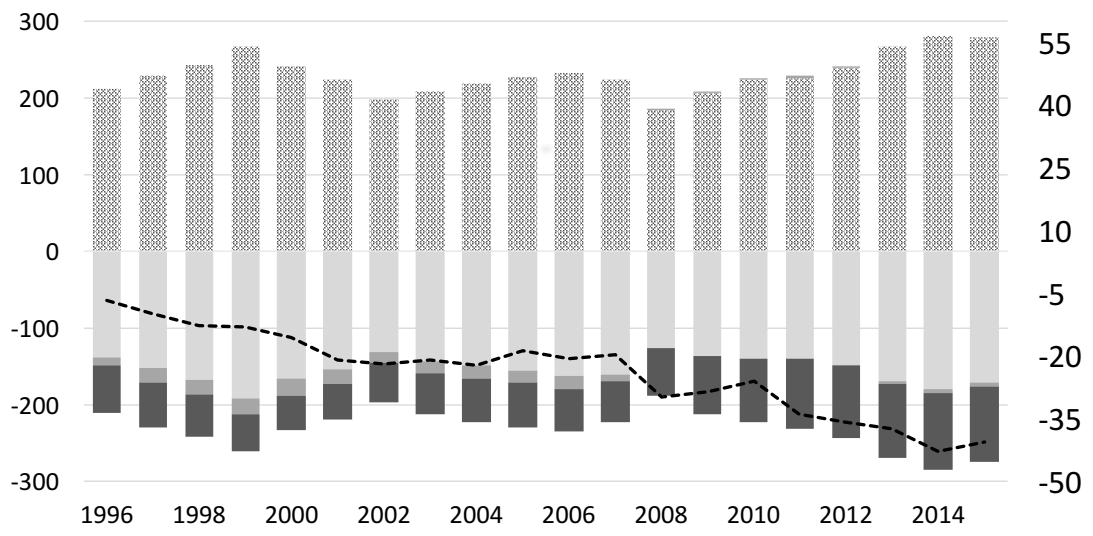

(a) Deficit Countries

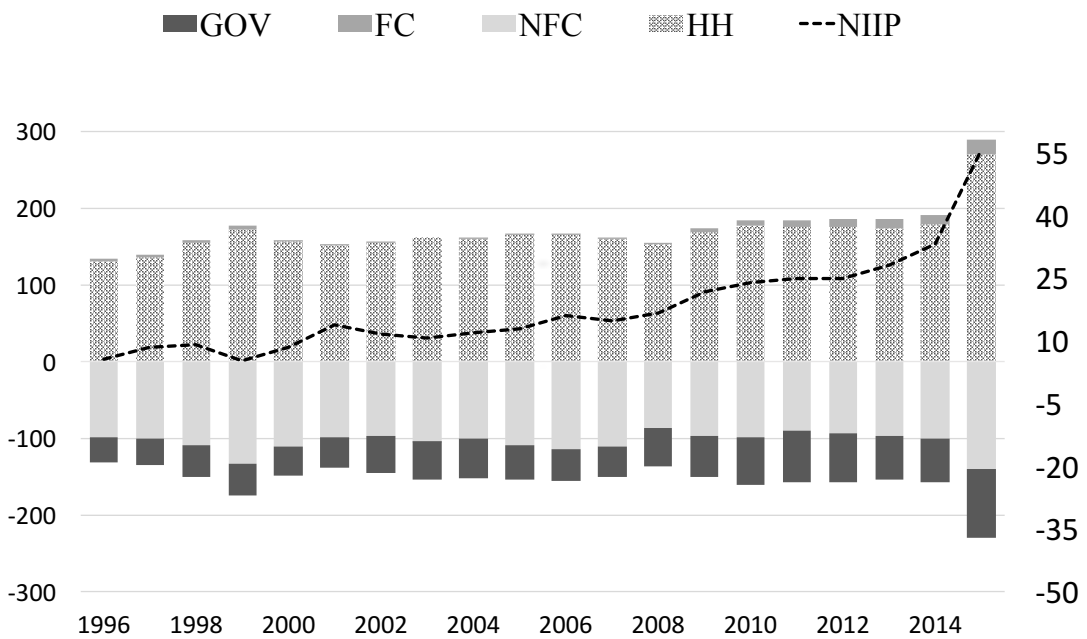

(b) Surplus Countries

Note: In percent of group GDP. GOV: Government, FC: Financial Corporations, NFC: Non-Financial Corporations, HH: Households, NIIP: Net International Investment Position. Current account surplus countries are: France, Belgium, Sweden, the Netherlands, Canada, Denmark, Norway, Germany, Finland, Austria, and Japan. Current account deficit countries are: Portugal, Cyprus, the United Kingdom, Lithuania, Spain, Greece, Czech Republic, Hungary, the United States, Slovak Republic, Italy, and Estonia. 
Figure D4: Flow and Stock-Flow Adjustments of Sectoral Balance Sheets

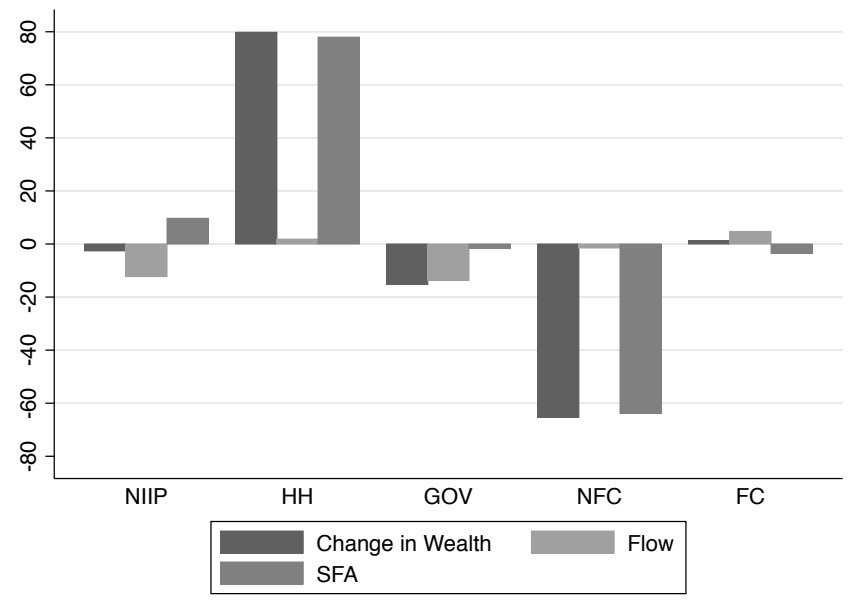

(a) Deficit Countries: 2003-2007

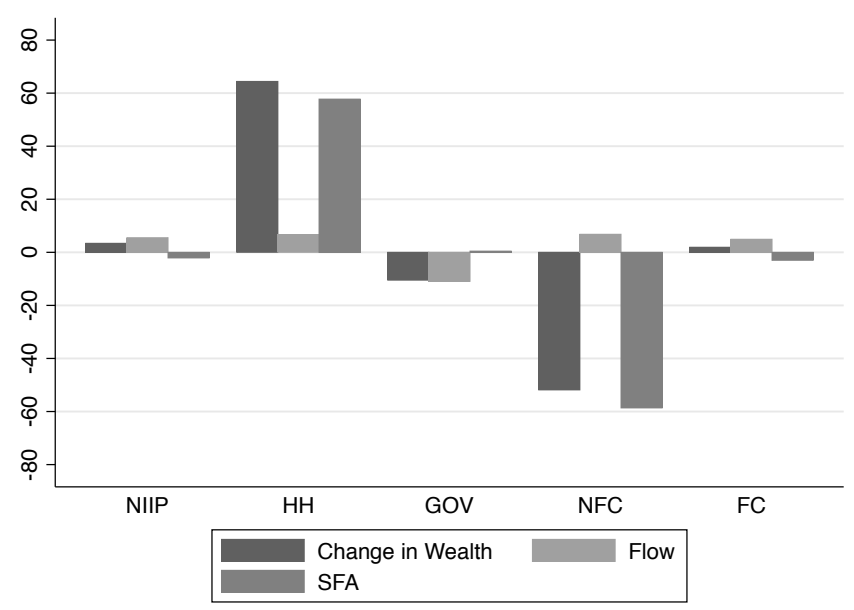

(c) Surplus Countries: 2003-2007

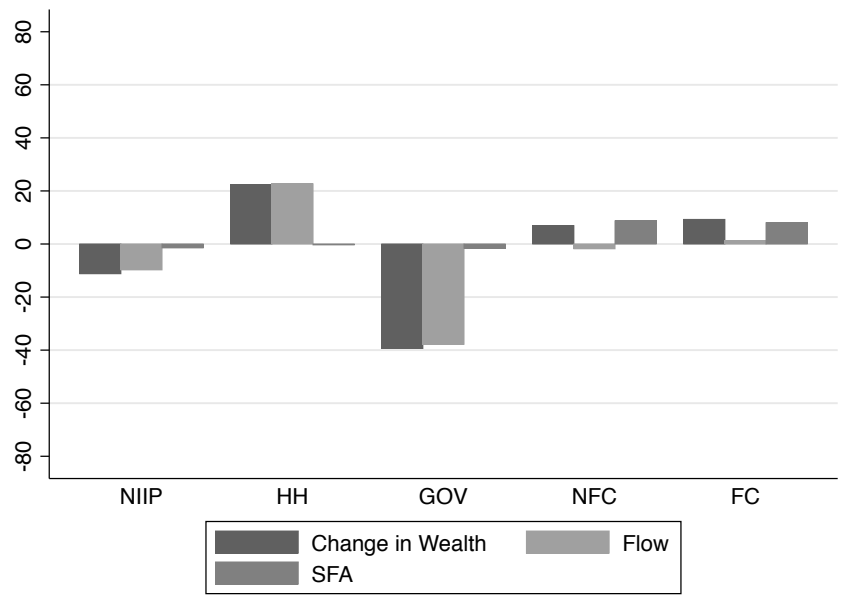

(b) Deficit Countries: 2008-2013

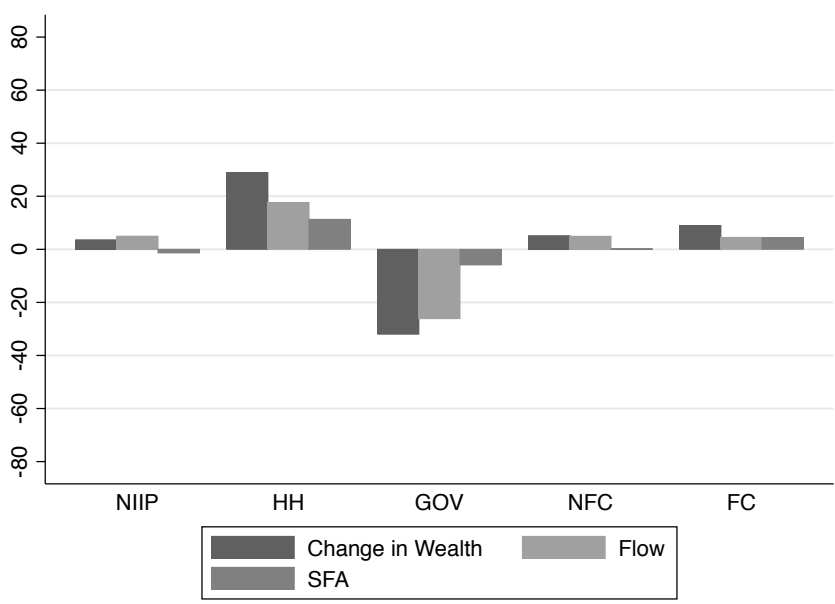

(d) Surplus Countries: 2008-2013

Note: HH: Households, NFC: Non-Financial Corporations, FC: Financial Corporations, GOV: Government. Change in wealth is the change in net financial position of the sector. Flow is the cumulated net financial balance and Stock-Flow Adjustment (SFA) is the difference between the two. Stock-Flow Adjustment (SFA) not due to transactions and is used as a proxy for valuation changes. Current account surplus countries are: France, Belgium, Sweden, the Netherlands, Canada, Denmark, Norway, Germany, Finland, Austria, and Japan. Current account deficit countries are: Portugal, Cyprus, the United Kingdom, Lithuania, Spain, Greece, Czech Republic, Hungary, the United States, Slovak Republic, Italy, and Estonia. In percent of GDP. 
Figure D5: Change in Financial Wealth: NIIP and Across Domestic Sectors

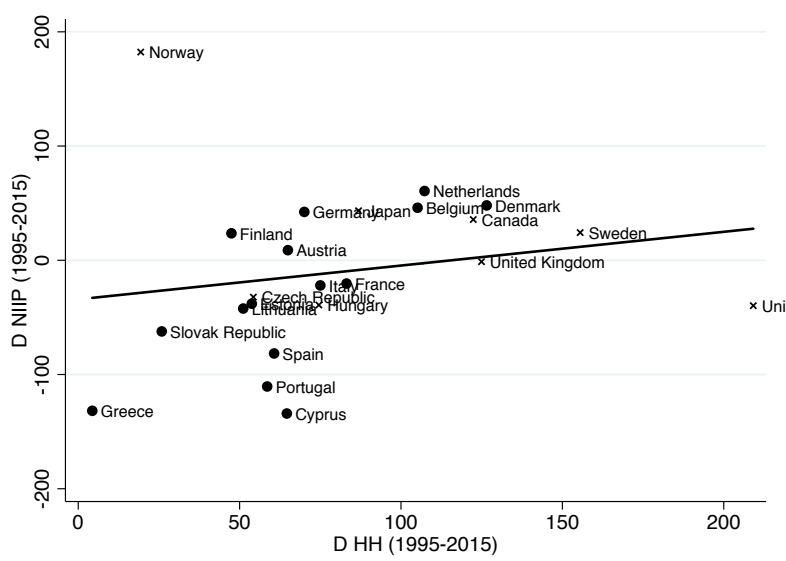

(a) $\mathrm{HH}$

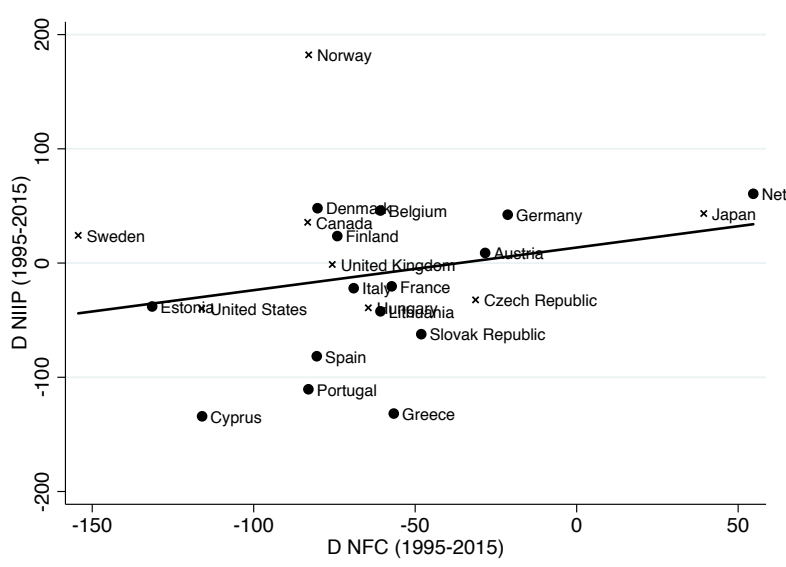

(c) NFC

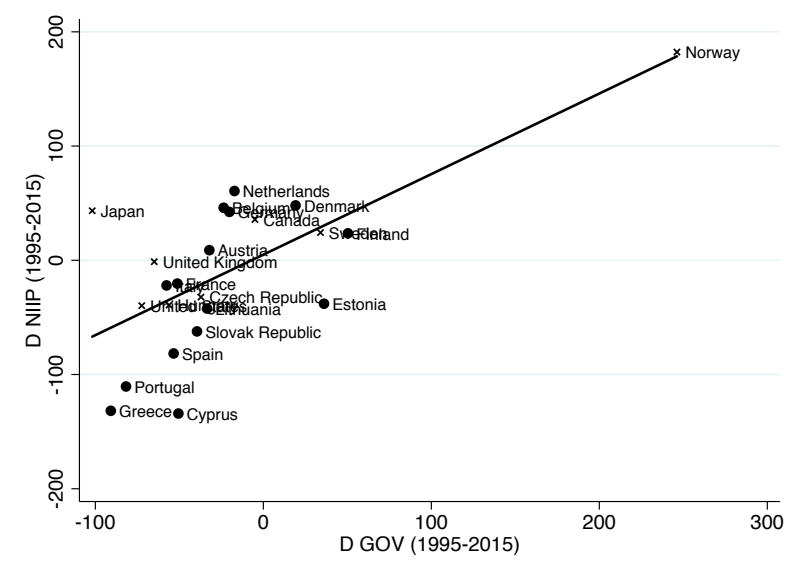

(b) GOV

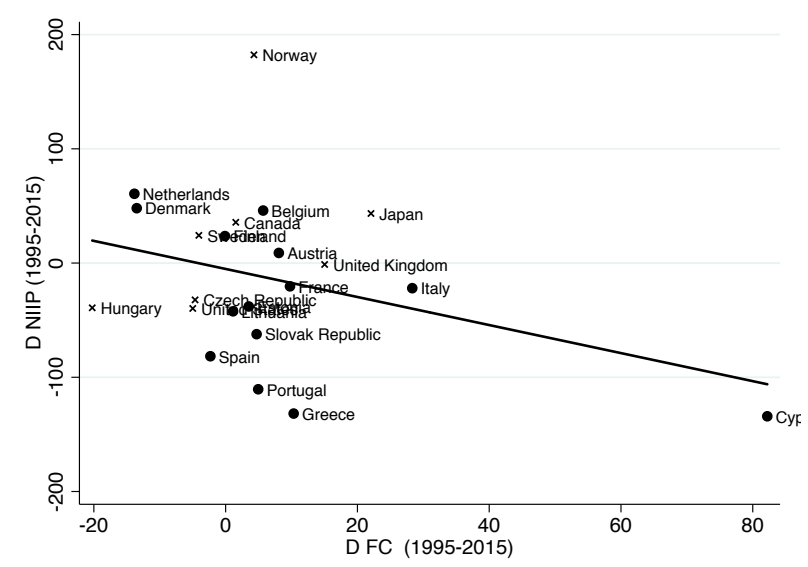

(d) FC

Note: HH: Households, NFC: Non-Financial Corporations, GOV: Government, FC: Financial Corporations. Change in financial net wealth of each sector between 1995 and 2015 against the change in net international investment position. In percent of GDP. Crosses represent economies with pegged exchange rate regimes and circles represent economies with non-pegged exchange rate regimes. 
Figure D6: Post-Crisis Adjustment Process Within Sectors

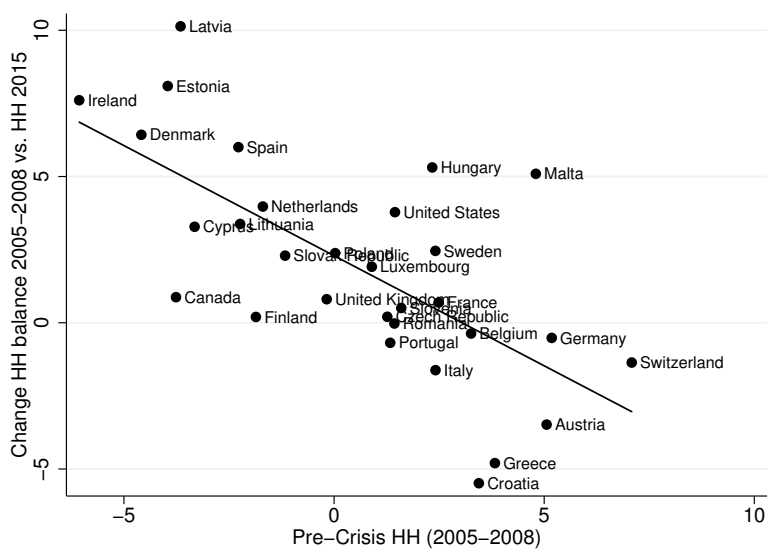

(a) $\mathrm{HH}$

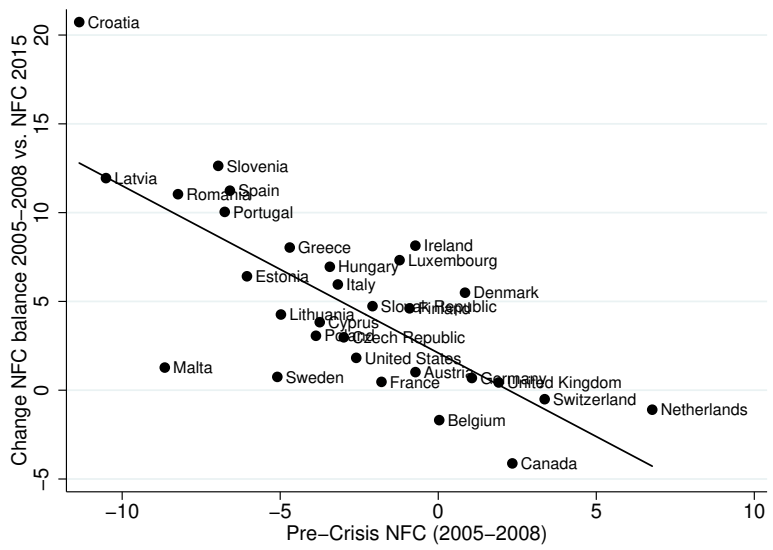

(c) NFC

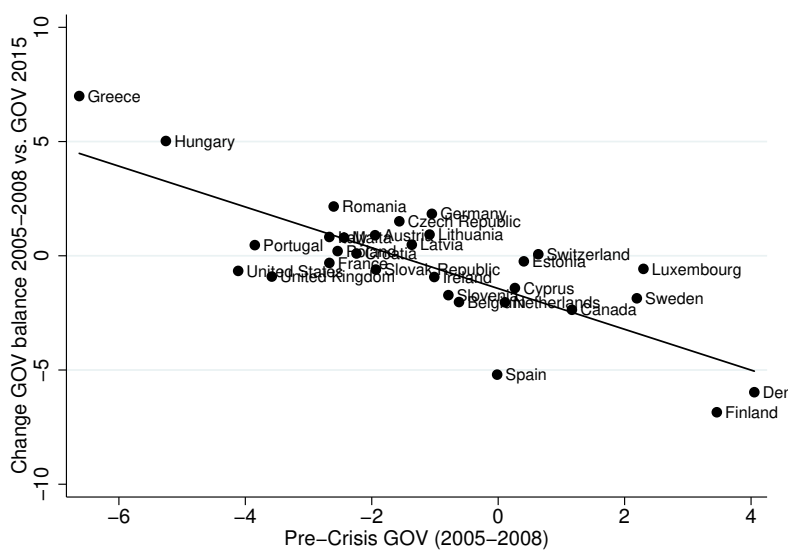

(b) GOV

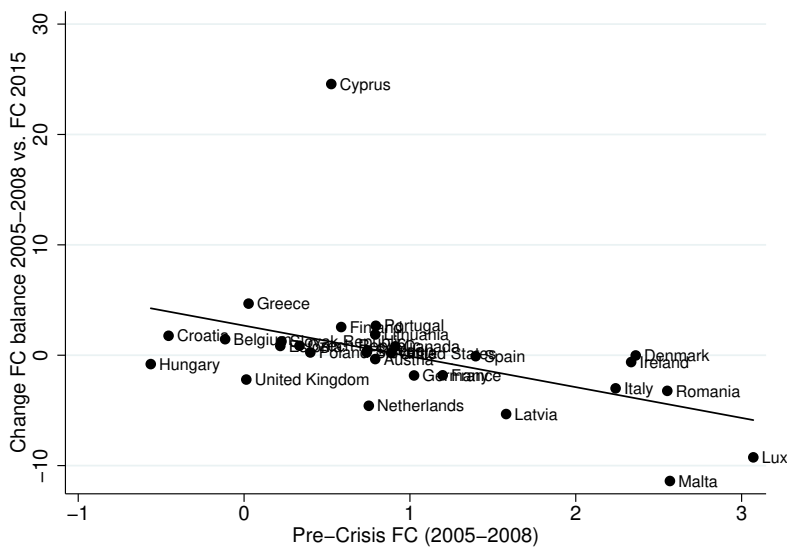

(d) $\mathrm{FC}$

Note: Scatter of the sector's average pre-crisis balance (between 2005 and 2008) and its the post-crisis adjustment (i.e. the change between the average balance between 2005-2008 and its 2015 value). Households (HH), Government (GOV), Non-Financial Corporations (NFC), Financial Corporations (FC). In percent of GDP. 
Figure D7: Post-Crisis Adjustment of the Current Account and Contemporaneous Sector Balance

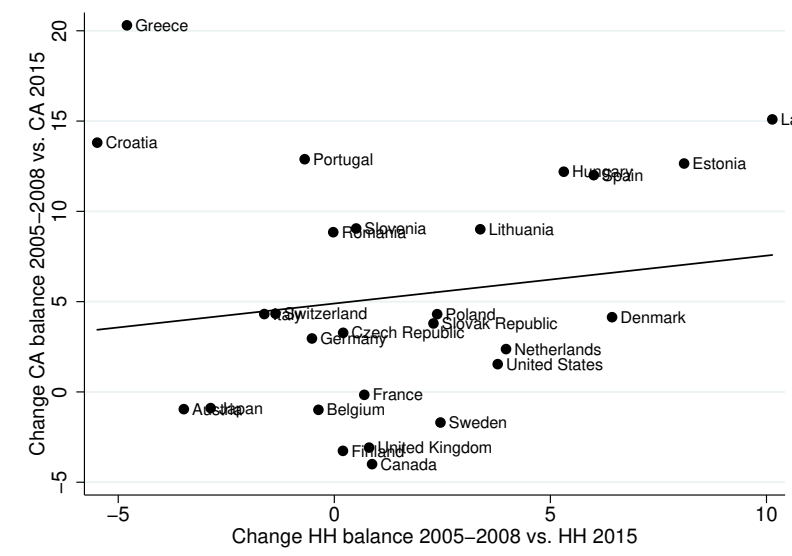

(a) $\mathrm{HH}$

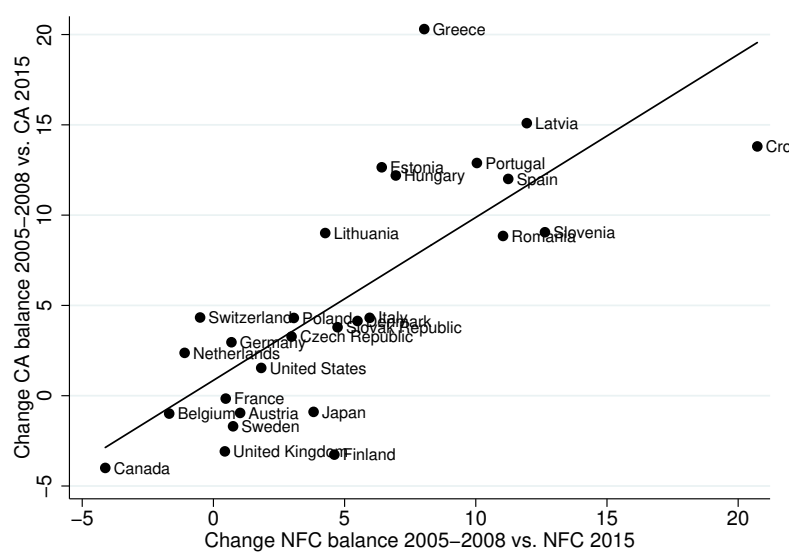

(c) NFC

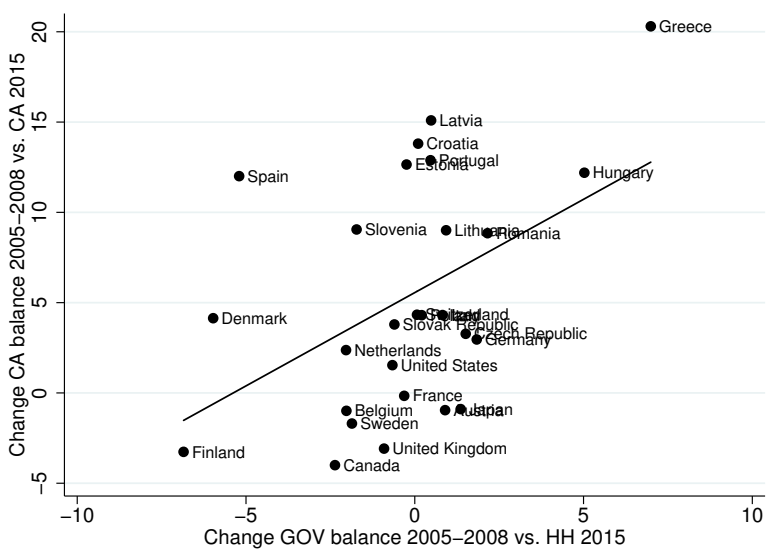

(b) GOV

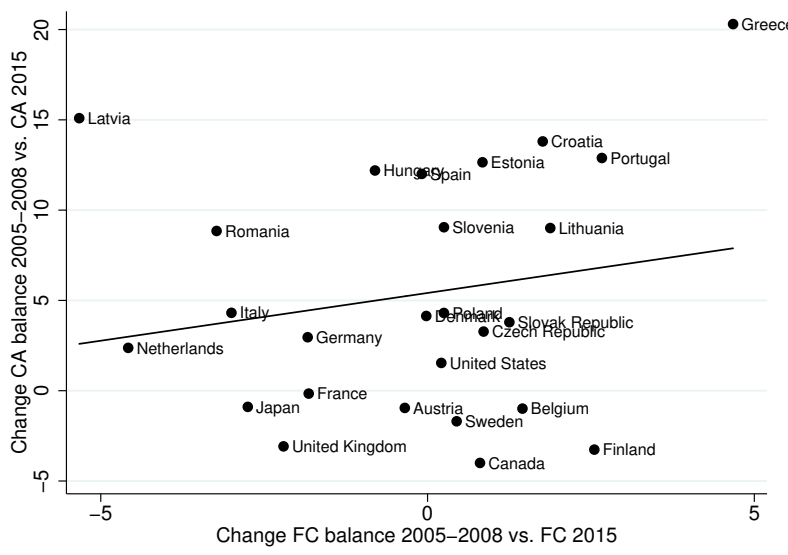

(d) $\mathrm{FC}$

Note: Plot of the post-crisis adjustment (i.e. the change between the average balance between 2005-2008 and its 2015 value) of the current account against the contemporaneous sectoral adjustment. Households (HH), Government (GOV), Non-Financial Corporations (NFC), Financial Corporations (FC). In percent of GDP. 
Figure D8: Average Adjustment in Financial Assets and Liabilities Conditional on Pre-Crisis Current Account Gap

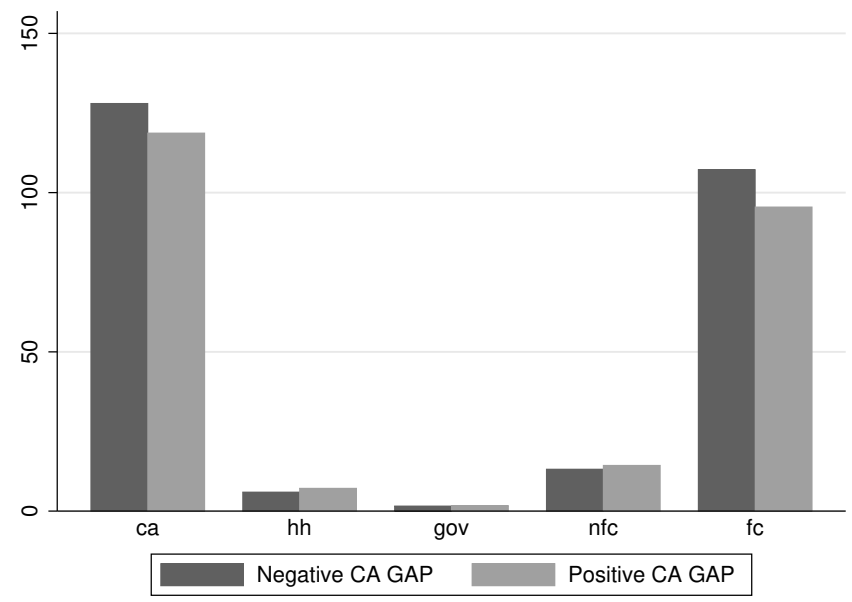

(a) Pre-Crisis Flows: Assets

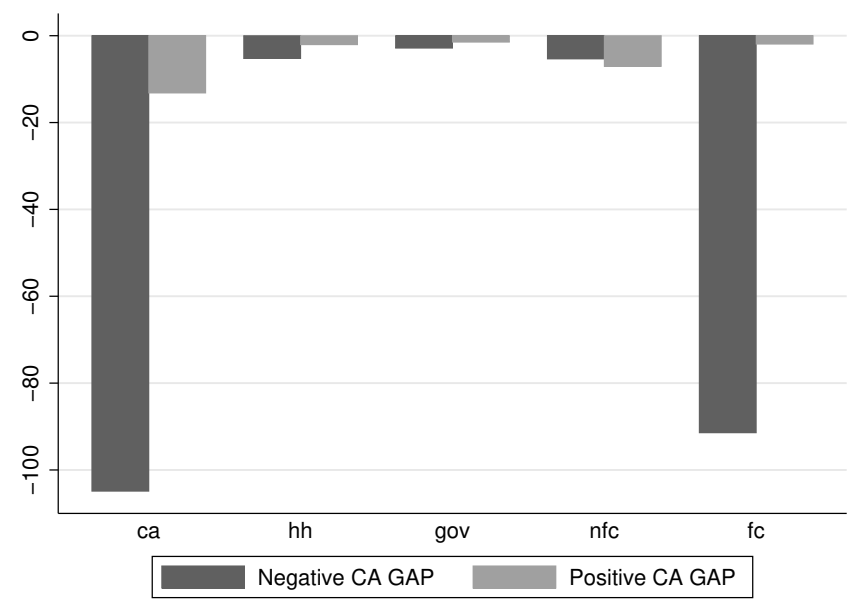

(c) Post-Crisis Flows: Assets

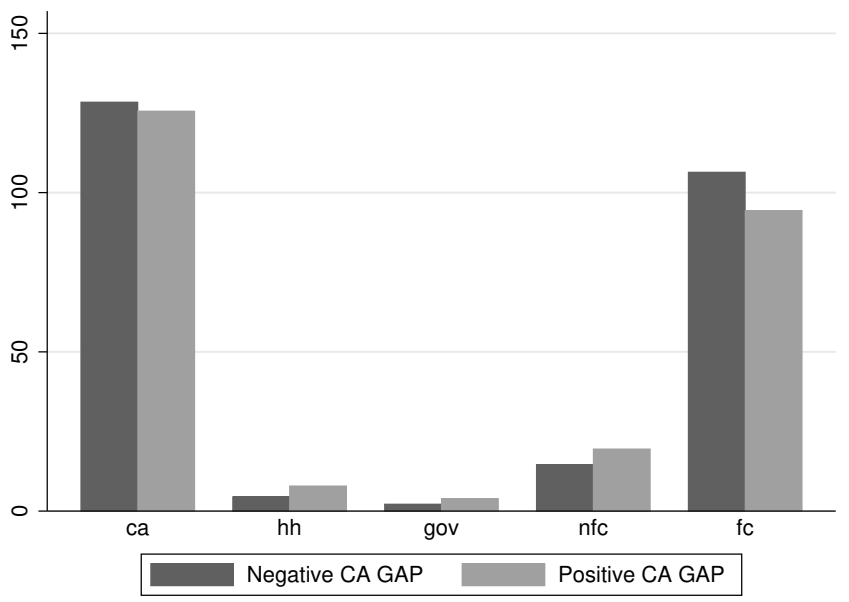

(b) Pre-Crisis Flows: Liabilities

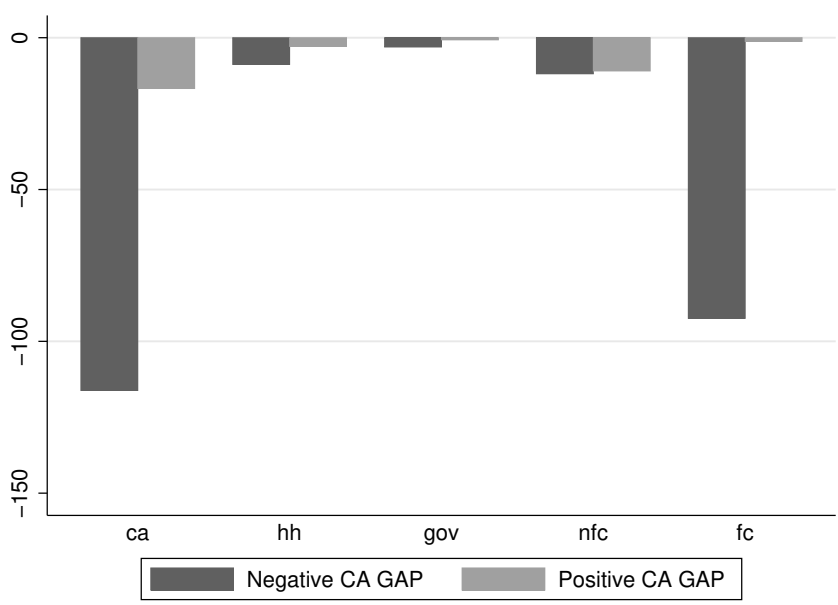

(d) Post-Crisis Flows: Liabilities

Note: Figure (a) shows the average pre-crisis imbalance between 2005-2008 for the transactions of financial assets and liabilities and each sectoral transactions in percent of 2015 GDP. The countries are split into negative and positive pre-crisis current account gap. Figure (b) shows the average adjustment of the transactions since 2008 (i.e. the change between the average transactions between 2005-2008 and its 2015 value) in percent of 2015 GDP. 
Figure D9: Sectoral Flows During Persistent Current Account Deficits

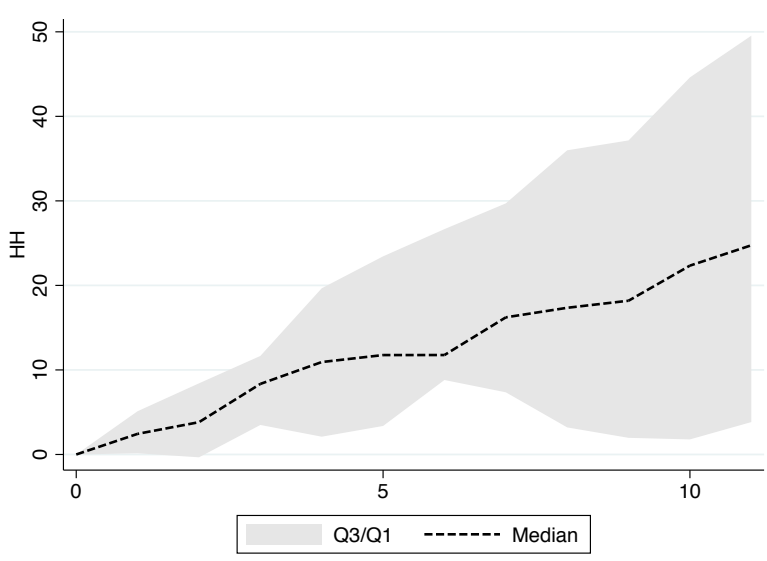

(a) $\mathrm{HH}$

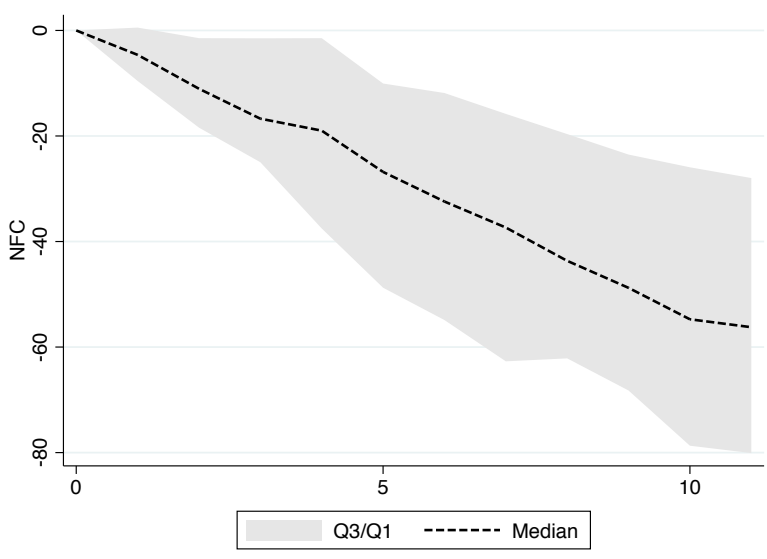

(c) NFC

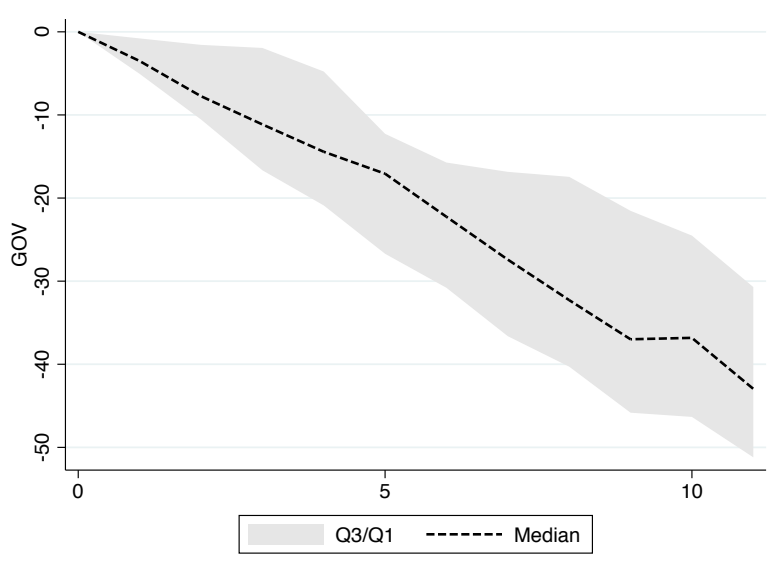

(b) GOV

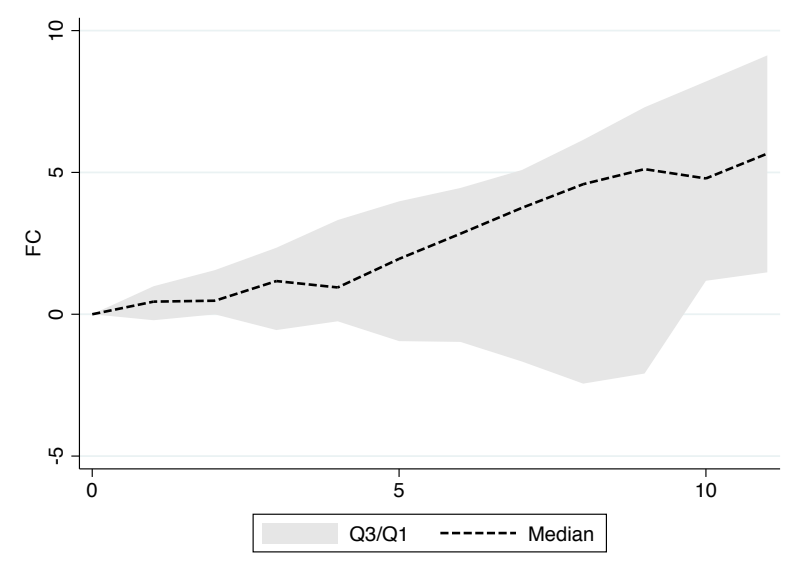

(d) FC

Note: Cross-country median with error bands of each sector's net financial balance during the external episode. 0 marks the beginning of the episode. In computing the median values, we drop the most extreme cases: Iceland, Luxembourg, Malta, and Cyprus. See following Tables for a complete list of the external episodes. All Variables in percent of GDP. 
Figure D10: Sectoral Flows During Persistent Current Account Surpluses

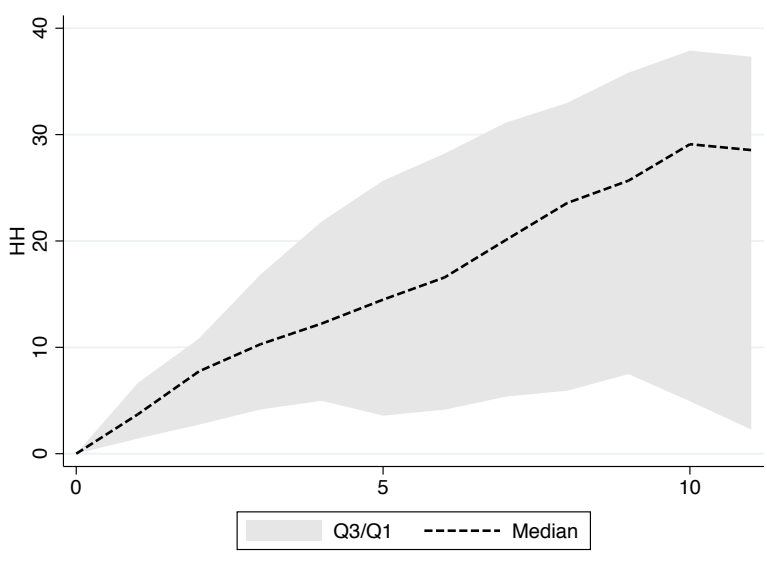

(a) $\mathrm{HH}$

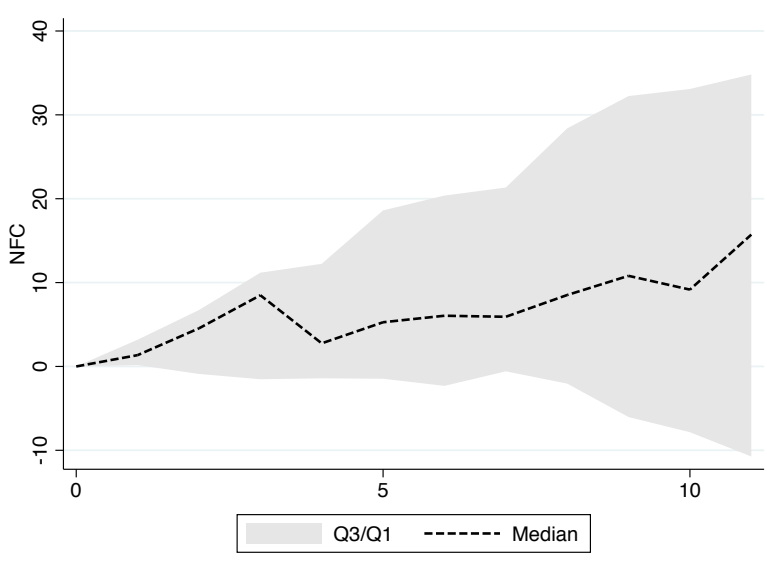

(c) NFC

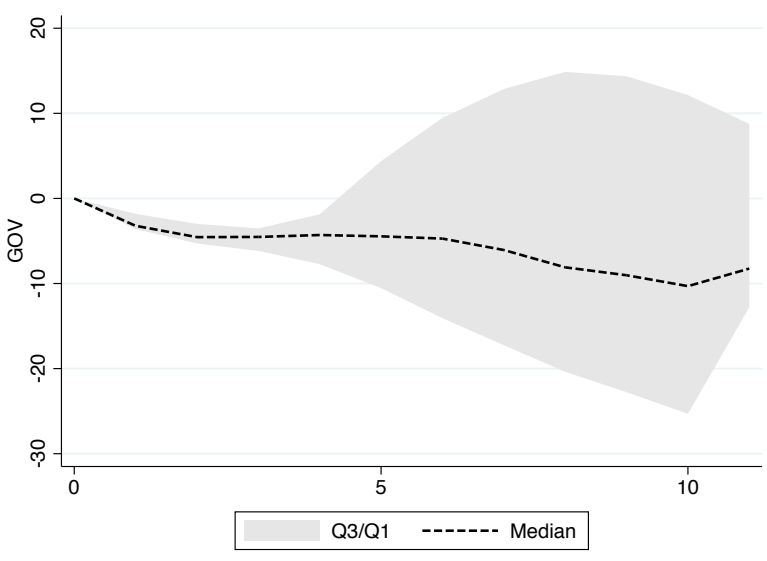

(b) GOV

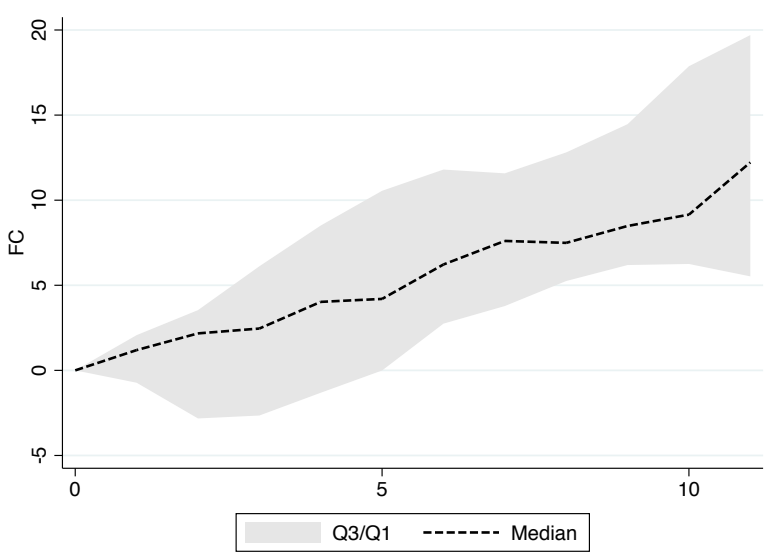

(d) $\mathrm{FC}$

Note: Cross-country median with error bands of each sector's net financial balance during the external episode. 0 marks the beginning of the episode. In computing the median values, we drop the most extreme cases: Luxembourg. See following Tables for a complete list of the external episodes. All Variables in percent of GDP. 
Figure D11: Sectoral Stocks During Persistent Current Account Surpluses

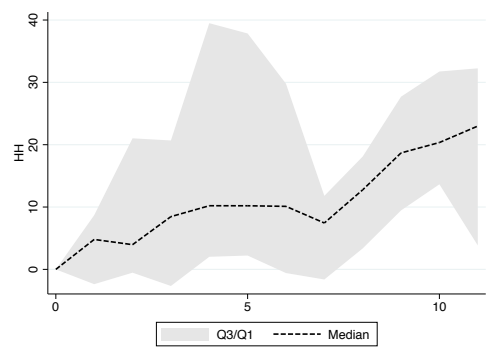

(a) $\mathrm{HH}$

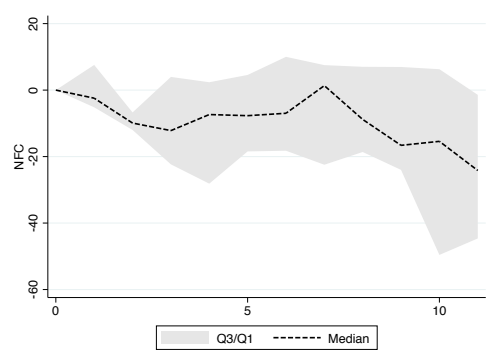

(c) NFC

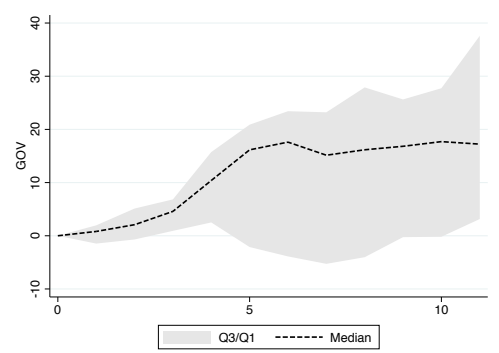

(b) GOV

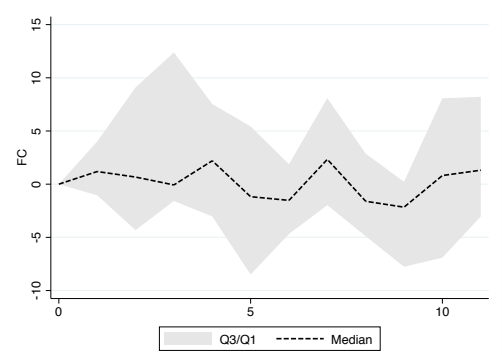

(d) FC

Figure D12: Sectoral Stocks During Persistent Current Account Deficits

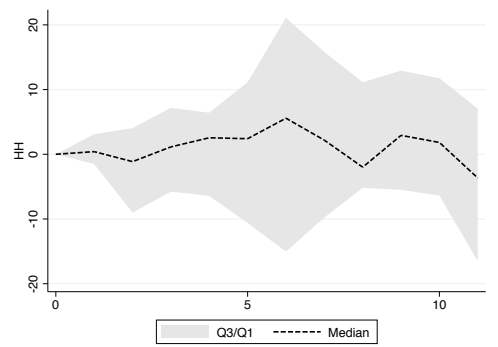

(a) $\mathrm{HH}$

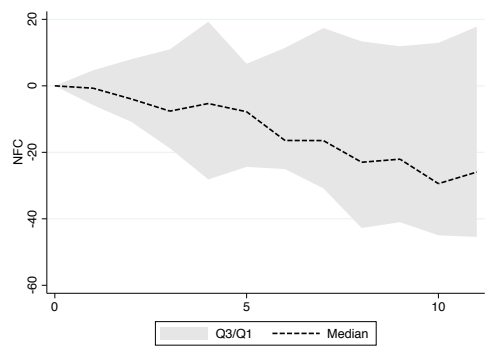

(c) NFC

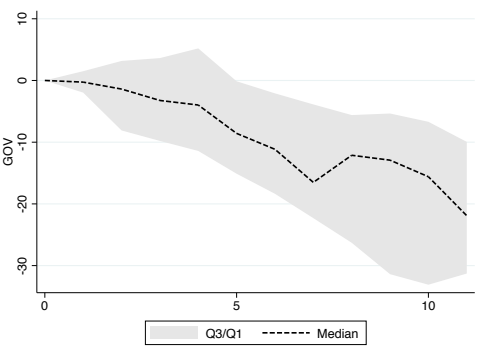

(b) GOV

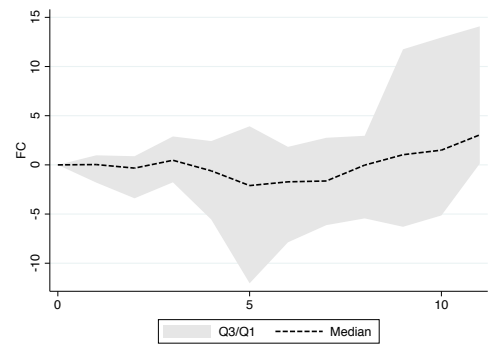

(d) FC

Note: Cross-country median with error bands of each sector's net financial position during the external episode. 0 marks the beginning of the episode. In computing the median values, we drop the most extreme cases: Luxembourg and Malta. See following Tables for a complete list of the external episodes. All Variables in percent of GDP. 
Figure D13: Discrepancies Between Sector Accounts and BOP/IIP

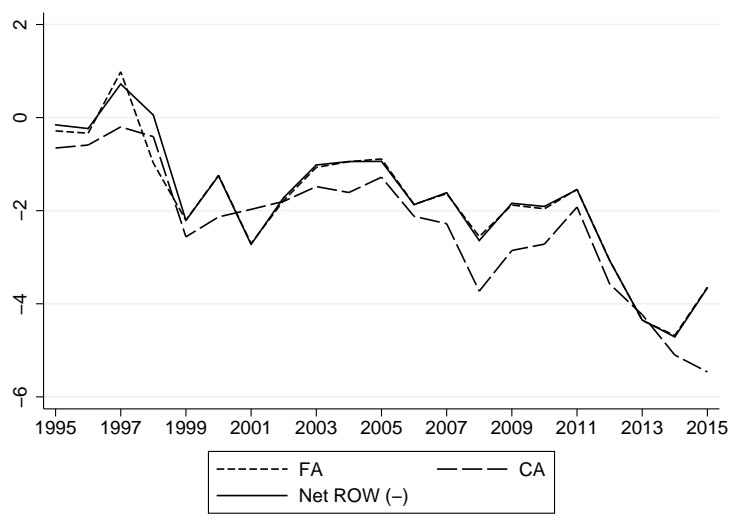

(a) Flow Balances-United Kingdom

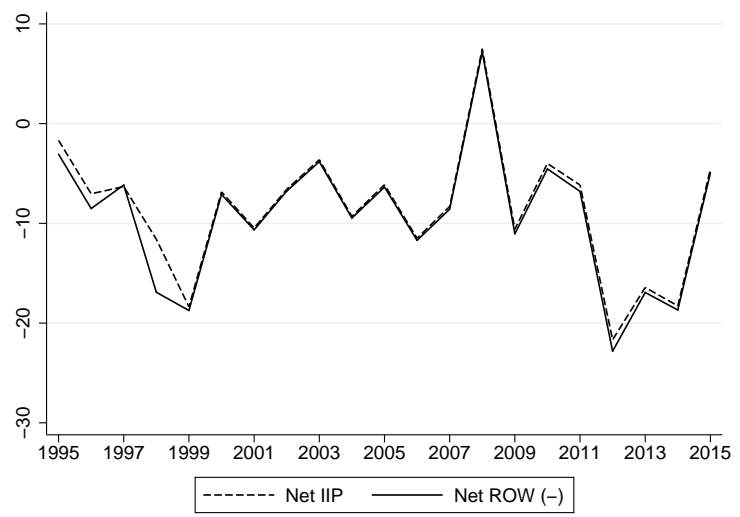

(c) Stock Positions-United Kingdom

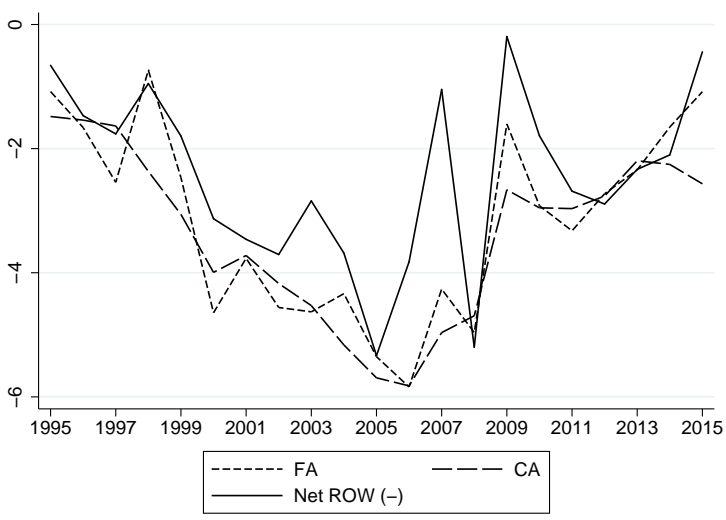

(b) Flows Balances-United States

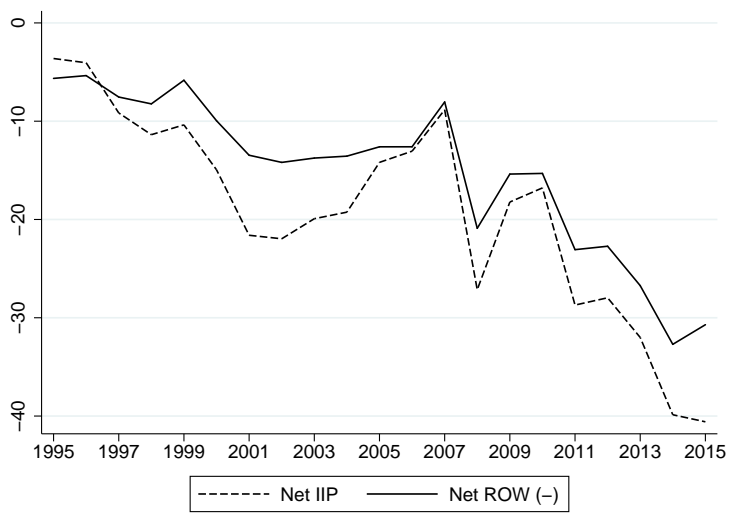

(d) Stock Positions-United States

Note: The Financial Account (FA), Current Account (CA) and the Net International Investment Position (Net IIP) are from the Balance of Payments and Investment Position Statistics (BOP/IIP). Net ROW (-) is the Rest of the World net financial balance from the sector accounts in graph (a) and (b) and the net financial position in graph (c) and (d). In both cases, the variables' signs are changed. All Variables in percent of GDP. 


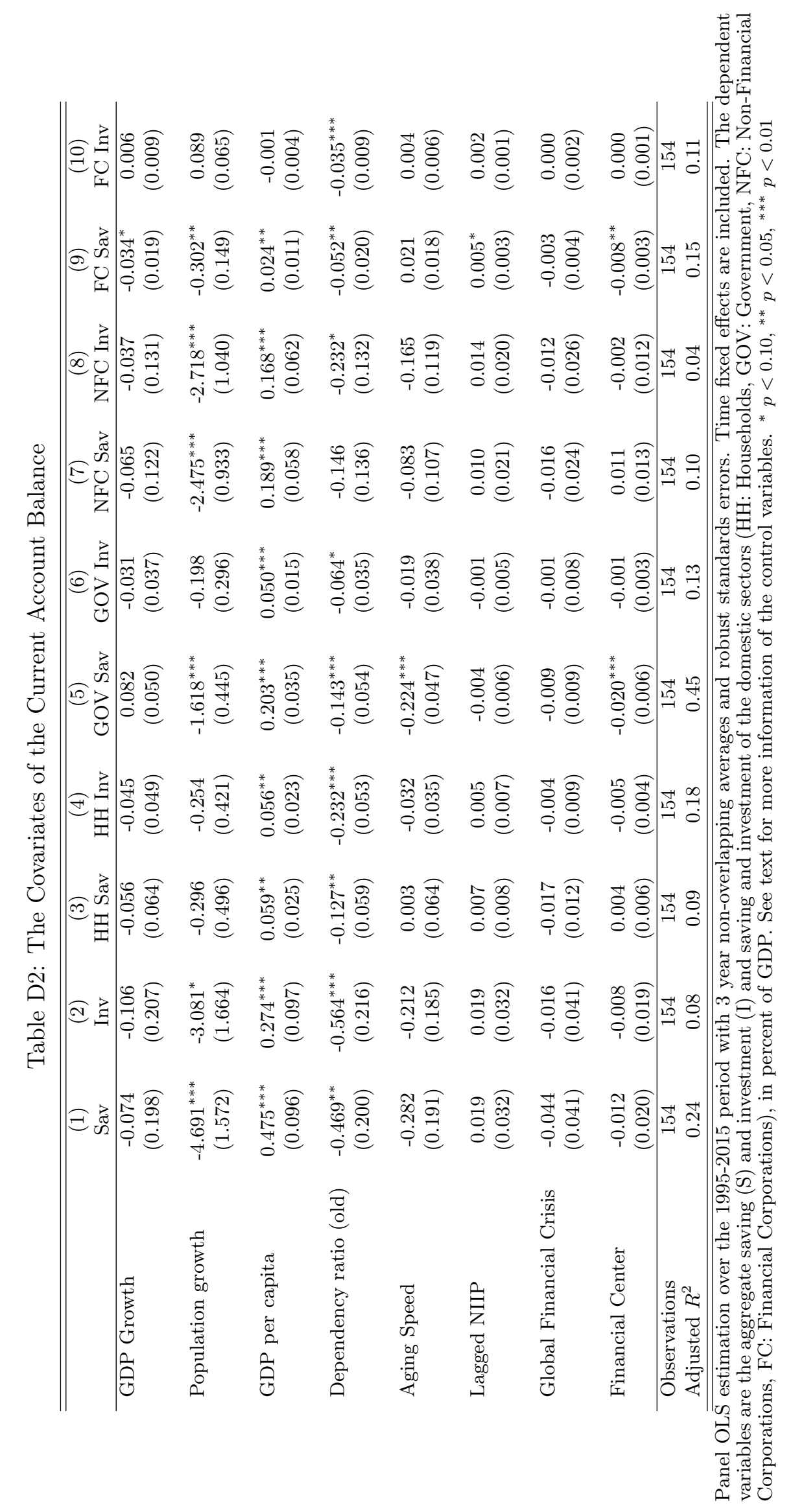


Table D3: The Covariates of the Current Account Balance: Lagged GOV Balance

\begin{tabular}{lccccc}
\hline \hline & $(1)$ & $(2)$ & $(3)$ & $(4)$ & $(5)$ \\
& $\mathrm{CA}$ & $\mathrm{HH}$ & $\mathrm{GOV}$ & $\mathrm{NFC}$ & $\mathrm{FC}$ \\
\hline GDP Growth & $-0.172^{*}$ & -0.006 & $0.099^{*}$ & $-0.198^{* * *}$ & -0.067 \\
& $(0.089)$ & $(0.077)$ & $(0.053)$ & $(0.064)$ & $(0.063)$ \\
Population growth & $-2.432^{* * *}$ & 0.125 & $-0.865^{* *}$ & $-1.258^{* *}$ & $-0.933^{* *}$ \\
& $(0.750)$ & $(0.515)$ & $(0.421)$ & $(0.599)$ & $(0.420)$ \\
GDP per capita & $0.164^{* * *}$ & 0.004 & $0.059^{* * *}$ & $0.055^{*}$ & 0.031 \\
& $(0.038)$ & $(0.032)$ & $(0.022)$ & $(0.032)$ & $(0.020)$ \\
Dependency ratio (old) & -0.076 & $0.161^{* * *}$ & -0.028 & $-0.246^{* * *}$ & -0.028 \\
& $(0.067)$ & $(0.050)$ & $(0.043)$ & $(0.064)$ & $(0.046)$ \\
Aging Speed & $0.133^{*}$ & $-0.101^{*}$ & -0.061 & $0.213^{* * *}$ & 0.038 \\
& $(0.068)$ & $(0.052)$ & $(0.052)$ & $(0.056)$ & $(0.041)$ \\
Lagged NIIP & 0.015 & 0.008 & -0.003 & 0.014 & -0.003 \\
& $(0.011)$ & $(0.006)$ & $(0.006)$ & $(0.010)$ & $(0.008)$ \\
Global Financial Crisis & $-0.042^{* * *}$ & 0.002 & $-0.039^{* * *}$ & 0.004 & -0.004 \\
& $(0.014)$ & $(0.011)$ & $(0.011)$ & $(0.013)$ & $(0.009)$ \\
Financial Center & $0.020^{* * *}$ & $0.010^{*}$ & -0.003 & $0.015^{* *}$ & -0.002 \\
L3.GOV & $(0.008)$ & $(0.005)$ & $(0.004)$ & $(0.007)$ & $(0.005)$ \\
& & & & & \\
Adjusted $R^{2}$ & $0.421^{* * *}$ & $-0.246^{* *}$ & $0.778^{* * *}$ & -0.099 & -0.012 \\
\hline \hline Pabervations & $(0.114)$ & $(0.097)$ & $(0.065)$ & $(0.088)$ & $(0.059)$ \\
\hline & 133 & 133 & 133 & 133 & 133 \\
& 0.61 & 0.21 & 0.77 & 0.38 & 0.02 \\
\hline
\end{tabular}

Panel OLS estimation over the 1995-2015 period with 3 year non-overlapping averages and robust standards errors. Time fixed effects are included. The dependent variables are the current account balance $(\mathrm{CA})$ and the net financial balances of the main domestic sectors $(\mathrm{HH}$ : Households, GOV: Government, NFC: Non-Financial Corporations, FC: Financial Corporations), in percent of GDP. See text for more information of the control variables. ${ }^{*} p<0.10$, ** $p<0.05,{ }^{* * *} p<0.01$ 
Table D4: Alternative Specification: EBA-Lite, IMF (2016)

\begin{tabular}{|c|c|c|c|c|c|}
\hline & $\begin{array}{l}\text { (1) } \\
\text { CA }\end{array}$ & $\begin{array}{l}(2) \\
\mathrm{HH}\end{array}$ & $\begin{array}{c}(3) \\
\text { GOV }\end{array}$ & $\begin{array}{c}(4) \\
\text { NFC }\end{array}$ & $\begin{array}{l}(5) \\
\text { FC }\end{array}$ \\
\hline Private credit/GDP, demeaned & $\begin{array}{l}-0.013 \\
(0.015)\end{array}$ & $\begin{array}{l}-0.021 \\
(0.013)\end{array}$ & $\begin{array}{c}-0.019^{*} \\
(0.011)\end{array}$ & $\begin{array}{c}0.026 \\
(0.018)\end{array}$ & $\begin{array}{c}0.021 \\
(0.014)\end{array}$ \\
\hline Change in reserves/GDP & $\begin{array}{l}-0.038 \\
(0.157)\end{array}$ & $\begin{array}{c}0.182 \\
(0.168)\end{array}$ & $\begin{array}{l}-0.245 \\
(0.156)\end{array}$ & $\begin{array}{l}-0.260 \\
(0.174)\end{array}$ & $\begin{array}{c}0.147 \\
(0.163)\end{array}$ \\
\hline Change in reserves $/ \mathrm{GDP} \times \mathrm{K}$ controls & $\begin{array}{c}0.004 \\
(0.004)\end{array}$ & $\begin{array}{c}0.001 \\
(0.006)\end{array}$ & $\begin{array}{l}0.005^{*} \\
(0.003)\end{array}$ & $\begin{array}{c}0.006 \\
(0.005)\end{array}$ & $\begin{array}{c}-0.004 \\
(0.004)\end{array}$ \\
\hline K controls & $\begin{array}{c}0.305^{* * *} \\
(0.098)\end{array}$ & $\begin{array}{c}0.110 \\
(0.085)\end{array}$ & $\begin{array}{l}0.099^{*} \\
(0.055)\end{array}$ & $\begin{array}{c}0.140 \\
(0.104)\end{array}$ & $\begin{array}{r}-0.039 \\
(0.065)\end{array}$ \\
\hline GDP growth-forecast in 5 years & $\begin{array}{l}-0.674 \\
(0.528)\end{array}$ & $\begin{array}{c}-0.923^{*} \\
(0.480)\end{array}$ & $\begin{array}{c}0.883^{* *} \\
(0.396)\end{array}$ & $\begin{array}{c}-0.928^{*} \\
(0.515)\end{array}$ & $\begin{array}{c}0.035 \\
(0.446)\end{array}$ \\
\hline Lagged NIIP & $\begin{array}{l}-0.000 \\
(0.013)\end{array}$ & $\begin{array}{l}-0.006 \\
(0.008)\end{array}$ & $\begin{array}{l}-0.003 \\
(0.008)\end{array}$ & $\begin{array}{c}0.009 \\
(0.013)\end{array}$ & $\begin{array}{c}0.003 \\
(0.008)\end{array}$ \\
\hline L.Output per worker-relative to top 3 economies $\times \mathrm{K}$ controls & $\begin{array}{c}0.006^{* * *} \\
(0.002)\end{array}$ & $\begin{array}{c}0.002 \\
(0.002)\end{array}$ & $\begin{array}{c}0.003^{* * *} \\
(0.001)\end{array}$ & $\begin{array}{c}0.003 \\
(0.002)\end{array}$ & $\begin{array}{r}-0.001 \\
(0.001)\end{array}$ \\
\hline L.Output per worker-relative to top 3 economies & $\begin{array}{c}0.125^{* * *} \\
(0.031)\end{array}$ & $\begin{array}{c}0.038 \\
(0.024)\end{array}$ & $\begin{array}{c}0.024 \\
(0.021)\end{array}$ & $\begin{array}{l}0.050^{*} \\
(0.027)\end{array}$ & $\begin{array}{r}-0.000 \\
(0.020)\end{array}$ \\
\hline Oil and Natural Gas Trade Balance*resource temporariness & $\begin{array}{c}0.252^{* * *} \\
(0.083)\end{array}$ & $\begin{array}{c}-0.183^{* * *} \\
(0.070)\end{array}$ & $\begin{array}{c}0.614^{* * *} \\
(0.072)\end{array}$ & $\begin{array}{c}-0.184^{* *} \\
(0.078)\end{array}$ & $\begin{array}{c}0.008 \\
(0.052)\end{array}$ \\
\hline Population growth & $\begin{array}{c}-1.524^{*} \\
(0.854)\end{array}$ & $\begin{array}{c}0.204 \\
(0.677)\end{array}$ & $\begin{array}{c}0.248 \\
(0.677)\end{array}$ & $\begin{array}{c}-2.608^{* * *} \\
(0.834)\end{array}$ & $\begin{array}{c}-0.074 \\
(0.475)\end{array}$ \\
\hline Dependency ratio (old) & $\begin{array}{l}-0.055 \\
(0.197)\end{array}$ & $\begin{array}{c}0.256 \\
(0.188)\end{array}$ & $\begin{array}{c}-0.308^{* *} \\
(0.135)\end{array}$ & $\begin{array}{c}-0.451^{* *} \\
(0.189)\end{array}$ & $\begin{array}{c}0.229 \\
(0.209)\end{array}$ \\
\hline Aging Speed & $\begin{array}{l}-0.200 \\
(0.422)\end{array}$ & $\begin{array}{c}0.005 \\
(0.373)\end{array}$ & $\begin{array}{c}-0.906^{* * *} \\
(0.288)\end{array}$ & $\begin{array}{l}-0.000 \\
(0.339)\end{array}$ & $\begin{array}{c}0.388 \\
(0.333)\end{array}$ \\
\hline Aging Speed $\times$ Dependency ratio $($ old $)$ & $\begin{array}{c}0.008 \\
(0.012)\end{array}$ & $\begin{array}{l}-0.006 \\
(0.010)\end{array}$ & $\begin{array}{c}0.025^{* * *} \\
(0.008)\end{array}$ & $\begin{array}{c}0.007 \\
(0.010)\end{array}$ & $\begin{array}{c}-0.011 \\
(0.009)\end{array}$ \\
\hline ICRG index & $\begin{array}{c}0.157^{* * *} \\
(0.057)\end{array}$ & $\begin{array}{c}-0.118^{* * *} \\
(0.040)\end{array}$ & $\begin{array}{c}0.219^{* * *} \\
(0.040)\end{array}$ & $\begin{array}{c}0.022 \\
(0.046)\end{array}$ & $\begin{array}{r}-0.010 \\
(0.030)\end{array}$ \\
\hline Financial Center & $\begin{array}{c}0.299 \\
(0.987)\end{array}$ & $\begin{array}{l}-0.301 \\
(0.655)\end{array}$ & $\begin{array}{l}-0.696 \\
(0.765)\end{array}$ & $\begin{array}{l}1.787^{*} \\
(0.904)\end{array}$ & $\begin{array}{r}-0.790 \\
(0.701)\end{array}$ \\
\hline Remittance/GDP & $\begin{array}{l}-0.414 \\
(0.499)\end{array}$ & $\begin{array}{c}0.245 \\
(0.464)\end{array}$ & $\begin{array}{l}-0.115 \\
(0.349)\end{array}$ & $\begin{array}{c}0.061 \\
(0.548)\end{array}$ & $\begin{array}{r}-0.748 \\
(0.637)\end{array}$ \\
\hline Terms of trade of goods $\times$ Trade openness & $\begin{array}{c}0.000 \\
(0.000)\end{array}$ & $\begin{array}{c}0.000^{* *} \\
(0.000)\end{array}$ & $\begin{array}{l}-0.000 \\
(0.000)\end{array}$ & $\begin{array}{c}0.000 \\
(0.000)\end{array}$ & $\begin{array}{r}-0.000 \\
(0.000)\end{array}$ \\
\hline Trade openness & $\begin{array}{l}-0.242 \\
(0.322)\end{array}$ & $\begin{array}{c}-0.498^{* *} \\
(0.242)\end{array}$ & $\begin{array}{l}0.382^{*} \\
(0.222)\end{array}$ & $\begin{array}{l}-0.358 \\
(0.308)\end{array}$ & $\begin{array}{c}0.031 \\
(0.221)\end{array}$ \\
\hline Terms of trade of goods & $\begin{array}{l}-0.001 \\
(0.001)\end{array}$ & $\begin{array}{l}-0.001 \\
(0.001)\end{array}$ & $\begin{array}{c}0.001^{* *} \\
(0.001)\end{array}$ & $\begin{array}{c}-0.002^{* * *} \\
(0.001)\end{array}$ & $\begin{array}{r}0.000 \\
(0.000)\end{array}$ \\
\hline Output gap & $\begin{array}{c}-0.519^{* * *} \\
(0.137)\end{array}$ & $\begin{array}{l}-0.213 \\
(0.136)\end{array}$ & $\begin{array}{c}0.030 \\
(0.165)\end{array}$ & $\begin{array}{l}-0.091 \\
(0.119)\end{array}$ & $\begin{array}{c}-0.236^{* *} \\
(0.116) \\
\end{array}$ \\
\hline $\begin{array}{l}\text { Observations } \\
\text { Adjusted } R^{2}\end{array}$ & $\begin{array}{l}128 \\
0.74\end{array}$ & $\begin{array}{l}128 \\
0.29\end{array}$ & $\begin{array}{l}128 \\
0.74\end{array}$ & $\begin{array}{l}128 \\
0.51\end{array}$ & $\begin{array}{l}128 \\
0.09\end{array}$ \\
\hline
\end{tabular}

$\overline{\text { Panel OLS estimation over the 1995-2015 period with } 3 \text { year non-overlapping averages and robust standards errors. }}$ No time fixed effects are included. The dependent variables are the current account and each net financial balances of the domestic sectors (HH: Households, GOV: Government, NFC: Non-Financial Corporations, FC: Financial Corporations), in percent of GDP. See text for more information of the control variables. ${ }^{*} p<0.10,{ }^{* *} p<0.05,{ }^{* * *}$ $p<0.01$ 
Table D5: Alternative Specification: Chinn (2017)

\begin{tabular}{lccccc}
\hline \hline & $(1)$ & $(2)$ & $(3)$ & $(4)$ & $(5)$ \\
& CA & HH & GOV & NFC & FC \\
\hline Dependency ratio (young) & $-0.241^{* *}$ & 0.055 & -0.084 & -0.122 & -0.085 \\
& $(0.101)$ & $(0.070)$ & $(0.078)$ & $(0.094)$ & $(0.060)$ \\
Lagged NIIP & 0.010 & $0.016^{* *}$ & $-0.016^{* *}$ & 0.015 & -0.006 \\
& $(0.011)$ & $(0.006)$ & $(0.007)$ & $(0.010)$ & $(0.007)$ \\
GDP per capita & $0.385^{* * *}$ & 0.005 & 0.055 & $0.281^{* * *}$ & -0.006 \\
& $(0.058)$ & $(0.045)$ & $(0.045)$ & $(0.051)$ & $(0.035)$ \\
GDP pc squared & $-0.001^{*}$ & $-0.001^{*}$ & $0.002^{* * *}$ & $-0.003^{* * *}$ & 0.000 \\
& $(0.001)$ & $(0.000)$ & $(0.000)$ & $(0.000)$ & $(0.000)$ \\
Dependency ratio (old) & $-0.156^{* *}$ & $0.155^{* * *}$ & -0.075 & $-0.259^{* * *}$ & 0.004 \\
& $(0.064)$ & $(0.051)$ & $(0.051)$ & $(0.069)$ & $(0.052)$ \\
Private Credit & & & & \\
& $-0.032^{* * *}$ & -0.007 & $-0.018^{* * *}$ & 0.002 & -0.002 \\
Log Terms of Trade & $(0.007)$ & $(0.006)$ & $(0.005)$ & $(0.008)$ & $(0.008)$ \\
& -2.416 & $7.800^{* * *}$ & $-11.868^{* * *}$ & 0.986 & 0.193 \\
GDP Growth & $(3.524)$ & $(2.198)$ & $(3.069)$ & $(3.083)$ & $(2.074)$ \\
& & & & & \\
Abservations & $-0.167^{* *}$ & 0.009 & 0.067 & $-0.164^{* * *}$ & -0.057 \\
\hline \hline & $(0.079)$ & $(0.068)$ & $(0.071)$ & $(0.061)$ & $(0.036)$ \\
\hline
\end{tabular}

Panel OLS estimation over the 1995-2015 period with 3 year non-overlapping averages and robust standards errors. Time fixed effects are included. The dependent variables are the current account balance $(\mathrm{CA})$ and the net financial balances of the main domestic sectors $(\mathrm{HH}$ : Households, GOV: Government, NFC: Non-Financial Corporations, FC: Financial Corporations), in percent of GDP. See text for more information of the control variables. ${ }^{*} p<0.10$, ** $p<0.05,{ }^{* * *} p<0.01$ 